
AND CANISTER GLASS CORRELATION TEST

Brent Pulsipher

Pacific Northwest National Laboratory

December 1990

Letter Report Prepared for West Valley Nuclear Services by Pacific Northwest Laboratory, Richland, Washington

Pacific Northwest National Laboratory Operated for the U.S. Department of Energy by Battelle

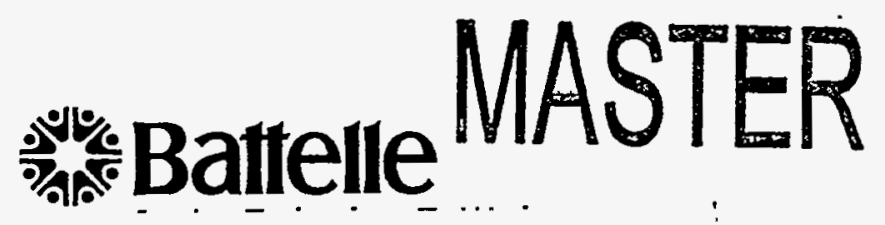




\section{STATISTICAL ANALYSIS OF SHARD AND CANISTER GLASS CORRELATION TEST}

\section{Brent Pulsipher}

Pacific Northwest National Laboratory

December 1990

Letter Report Prepared for

West Valley Nuclear Services by

Pacific Northwest Laboratory, Richland, Washington

Pacific Northwest National Laboratory

Operated for the U.S. Department of Energy

by Battelle 


\title{
DISCLAIMER
}

This report was prepared as an account of work sponsored by an agency of the United States Government. Neither the United States Government nor any agency thereof, nor Battelle Memorial Institute, nor any of their employees, makes any warranty, express or implied, or assumes any legal liability or responsibility for the accuracy, completeness, or usefulness of any information, apparatus, product, or process disclosed, or represents that its use would not infringe privately owned rights. Reference herein to any specific commercial product, process, or service by trade name, trademark, manufacturer, or otherwise does not necessarily constitute or imply its endorsement, recommendation, or favoring by the United States Government or any agency thereof, or Battelle Memorial Institute. The views and opinions of authors expressed herein do not necessarily state or reflect those of the United States Government or any agency thereof.

\section{PACIFIC NORTHWEST NATIONAL LABORATORY operated by \\ BATTELLE \\ for the \\ UNITED STATES DEPARTMENT OF ENERGY under Contract DE-AC06-76RLO 1830}

\author{
Printed in the United States of America \\ Available to DOE and DOE contractors from the \\ Office of Scientific and Technical Information, P.O. Box 62, Oak Ridge, TN 37831; \\ prices available from (615) 576-8401.
}

Available to the public from the National Technical Information Service, U.S. Department of Commerce, 5285 Port Royal Rd., Springfield, VA 22161 


\section{DISCLAIMER}

Portions of this document may be illegible in electronic image products. Images are produced from the best available original document. 
This page intentionally left blank. 


\section{Summary}

The vitrification facility at West Valley, New York will be used to incorporate nuclear waste into a vitrified waste form. Waste Acceptance Preliminary Specifications (WAPS) will be used to determine the acceptability of the waste form product. These specifications require chemical characterization of the waste form produced. West Valley Nuclear Services (WVNS) intends to characterize canister contents by obtaining "shard" samples from the top of the canisters prior to final sealing.

A study was conducted to determine whether shard samples taken from the top of canisters filled with vitrified nuclear waste could be considered representative and therefore used to characterize the elemental composition of the entire canister contents. Three canisters produced during the SF-12 melter run conducted at WVNS were thoroughly sampled by core drilling at several axial and radial locations and by obtaining shard samples from the top of the canisters. Chemical analyses were performed and the resulting data were statistically analyzed by Pacific. Northwest.Laboratory (PNL). The following general conclusions were derived.

- The chemical compositions derived from the shard samples were not statistically different from those derived from core samples, with the exception of chromium and nickel. Therefore, chemical analyses performed on shard samples are representative of the canister contents.

- For chromium and nickel, the shard concentrations were higher than the core sample concentrations. This result is not very troublesome because the weight percents for these two elemental oxides are $<0.25 \%$, which exempts them from the WAPS 1.1.2 requirement for reporting because they have no significant effect on waste acceptance.

- No linear trends were observed within the canisters (from top to bottom), with the exception of barium and zinc which were employed as tracers during run SF-12. This suggests that process variations during the SF-12 run were appropriately controlled.

- Statistically significant batch-to-batch variations (differences between Melter Feed Tank (MFT) batch compositions) were detected for many of the elemental constituents. These batch variations were quite small but were detectable due to the many samples obtained.

- For the major elemental constituents (wt\% $>0.5 \%$ ), the within canister relative standard deviations (RSD) were less than 3.5\%, with the exception of magnesium ( $R S D=14 \%)$ and potassium ( $R S D=5.3 \%)$. This RSD includes analytical, sampling, axial, and radial variations. 
- If one can assume that the process controls employeed by WVNS during the SF-12 run are representative of those to be employeed during future melter runs, shard samples can be used to. characterize the canister contents. However, if batch-to-batch variations cannot be controlled to the acceptable levels observed from the SF-12 data, the representativeness of shard samples will be in question. The estimates of process and within-canister variations provided herein will prove valuable in determining the required frequency and number of shard samples to meet waste form qualification objectives. 


\section{Introduction}

Nuclear waste residing at West Valley, New York will be blended with glass-forming chemicals and be subjected to a ceramic melter. The vitrified product will be poured into canisters to be deposited in a geological repository. The glass waste form must meet specifications previously outlined in the Waste Acceptance Preliminary Specifications (WAPS). In order to demonstrate acceptability of the waste form, West Valley Nuclear Services plans on sampling and analyzing the glass product. The frequency and number of samples required to meet the specifications are being determined. This report deals with the logistics of obtaining a representative glass sample from a canister.

It is not feasible to obtain "random" samples from the canisters by core drilling at specific locations because this type of sampling would compromise the integrity of the canister and would increase the likelihood of water contacting the waste form. Likewise, obtaining grab samples from the pour stream would require a significant redesign of existing equipment. A more promising alternative is to obtain a "shard" sample from the top of the canister prior to permanent closure. However, a characterization of the canister contents from an analysis of the shard sample requires the demonstration that the shard sample is a representative sample from the canister.

An experiment to evaluate and demonstrate the representativeness of the shard samples was designed by PNL and WVNS. Samples were obtained and chemical analyses performed at WVNS. A statistical analysis of the data was then conducted at PNL. This report summarizes the findings of the statistical analysis and documents this experimental evaluation. It should be noted that this analysis applies only to the WVNS process. However, under several assumptions, the results may be applicable to other DOE waste-producing vitrification plants. 


\section{Experimental Design}

\section{Canister Selection}

The WVNS melter is continuously fed from the MFT. Replenishing of the MFT contents is performed on a batch basis. One MFT batch will be converted to approximately 4 canisters of vitrified waste form. Regardless of the amount of control imposed on the feed makeup process, each MFT batch composition will be slightly different. Figure 1 is a hypothetical illustration of how variations in the MFT batch composition would be manifest in the waste glass being poured into the canisters.

As a new MFT batch of material is initially fed into the melter, the composition of the glass product begins migrating from the previous MFT batch composition to the new MFT batch composition (as represented by the curved lines in Figure 1). The waste product in the first canister filled after initiating the new MFT batch feed may contain an amount of material produced from the previous MFT batch as well as some mixture of the old and new. batch materials. Thus, the final pours to the first canister could be represented by the first few tickmarks for a given MFT batch in Figure 1.

The waste form in the third and possibly fourth canisters filled would be more representative of the new MFT batch composition as shown by the leveling off portion of the curves in Figure 1. Thus, compositional differences between the waste product at the top of the canister and the bottom of the canister may not be very pronounced.

The material poured into the second canister filled after initiating a new MFT batch would be transitioning from the previous MFT composition to the new MFT composition. If significant differences exist between MFT batch compositions, these differences will be manifest by differences in composition within the second canister. The differences between the waste product composition at the top of the canister and the composition at the bottom of the canister is expected to be largest for the second canister (the greatest slope of the transitioning curve in Figure 1 would probably occur within the second canister). 


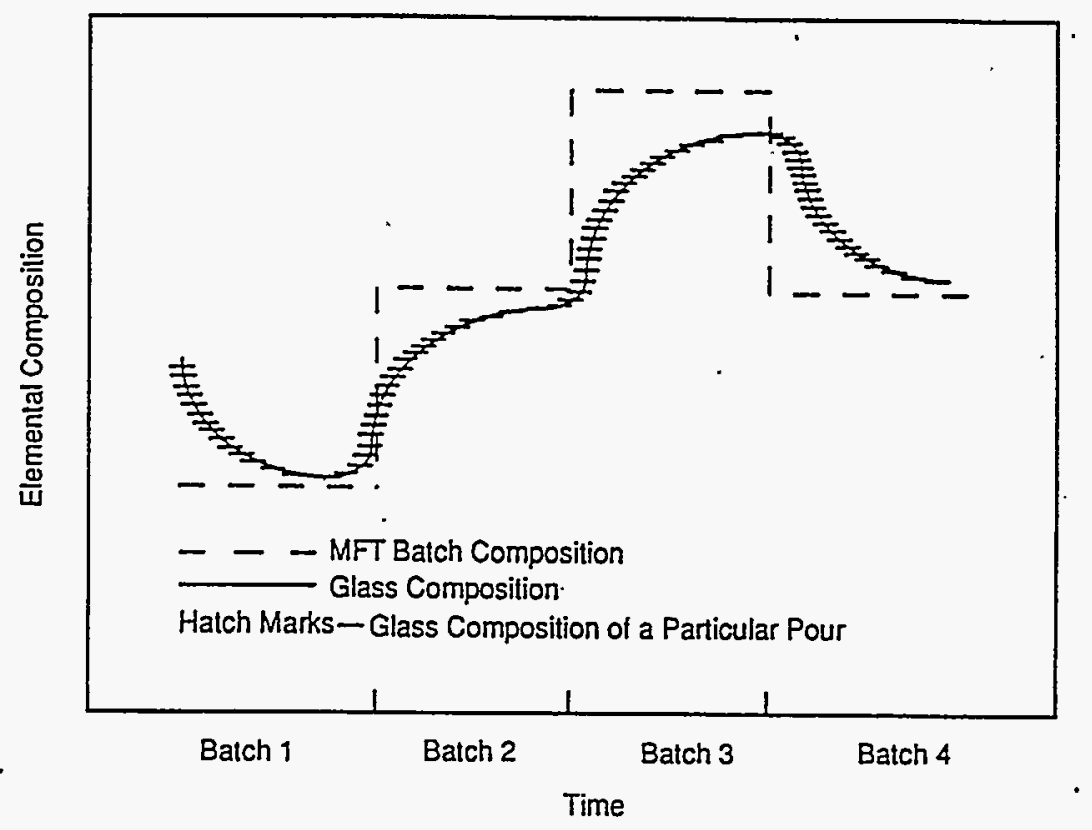

\section{FIGURE 2. Hypothetical Illustriation of Effect of MFT Batch Compositional Differences}

The objective of this study was to determine whether a shard sample taken from the top of a canister is representative of the entire contents of the canister. Based on the above discussion, it was determined that if a shard is not representative of the canister contents, the differences between the shard sample composition and the canister contents would be most pronounced within the second canister filled after initiating a new MFT batch. Thus, the variations within the second canisters represent a worst case scenario.

In the Fall of 1989, WVNS conducted an integrated melter run (SF-12) which produced approximately 15 canisters from three MFT batches. Control of the process was somewhat typical of that expected during future operations. Therefore, the batch-to-batch variations existing in the SF-12 run are representative of those which would occur during future operations. The second canisters produced (Cans 66A, 44A, and 47A) after initiating each of the three batches were chosen to evaluate the representativeness of shard samples. Shard samples were obtained from each canister produced and core samples were obtained from each second canister. The sampling schemes for each canister are outlined in the next section. It should be noted that $\mathrm{Ba}$ and $\mathrm{Zn}$ concentrations were purposely varied from batch-to-batch during the SF-12 run, so that they could be used as tracer elements. 


\section{Sampling Scheme}

The objectives of this study required that samples be obtained from canisters in a systematic manner. Core samples must be representative of the entire canister contents. If samples were obtained only on the outside edge or near the bottom of each canister, characterization of the canister contents based on those samples could be questioned. Moreover, a sufficient number of samples are required to adequately characterize the canister contents. Sample locations were chosen to maximize the amount of information that could be derived through statistical analysis while minimizing the sampling and analysis effort.

Each of the three canisters chosen for this study were core drilled and glass specimens were obtained from the core samples (see WVNS-TRQ-021 and WVNS-TP-021 for more details). Approximately 50 grams of glass were obtained at the 4,8 , and 12 inch radial locations for each core drill axial location. Each canister was core drilled at seven axial locations. The seven axial locations were determined such that material from every other airlift would be sampled. A schematic of the sampling scheme is shown in Figure 2. This sampling scheme permits an analysis of the radial variations and the axial variations within each canister, which are descibed in the statistical analysis section of this report. Three shard samples were also taken from each canister, as indicated in Figure 2. 


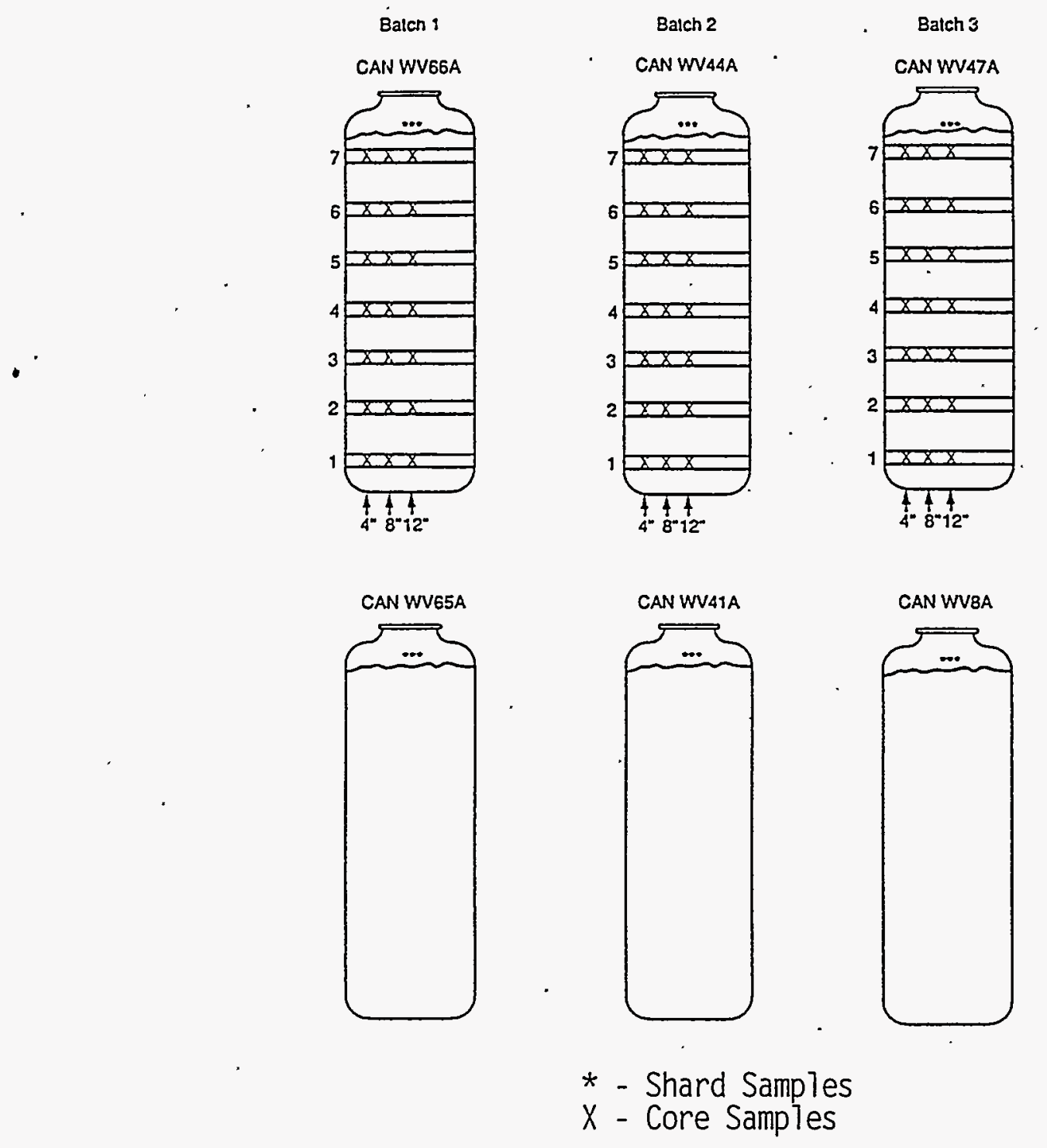

FIGURE 3. Sampling Scheme for Core Drilling and Shard Samples 
In addition to shard and core samples from canisters $66 \mathrm{~A}, 44 \mathrm{~A}$, and $47 \mathrm{~A}$, three shard samples were obtained from each canister immediately preceding each of the three canisters chosen for core drilling. These preceding shard samples should be similar in composition to the core samples taken from the bottom of the core drilled canisters.

A total of 81 glass samples were available for analysis ( 3 canisters * 7 axial locations * 3 radial locations +6 canisters $* 3$ shards per canister). Each of the 63 samples obtained from core drills were analyzed in duplicate, which resulted in a total of 144 chemical analyses. All chemical analyses were performed at WVNS and the data was delivered to PNL for statistical analysis. 


\section{Statistical Analysis Approach}

Chemical analyses were performed on the shard and core samples and reported as normalized oxide weight percents. Twenty-three elemental oxides were reported. This data was received by PNL and entered into a data base in a format that would facilitate statistical analysis.

In order to determine the appropriate statistical methods and models to be applied, an understanding of the experimental setup and uncertainties was necessary. A major hypothesis for this study was that the sample-to-sample and analytical variations would be sufficiently large relative to the differences between the compositions at various axial locations that these axial variations would be negligible. To test this hypothesis, an estimate of the sampling and analytical uncertainty was required. The analytical laboratory at WVNS randomized the analysis of the core samples, but conducted the duplicate analyses of each core sample sequentially. Thus, the variation between duplicate core sample analyses represents a very short-term analytical uncertainty. This short-term analytical variation would not be the appropriate measure of uncertainty to test the hypothesis of axial variations because the variations between compositions at different axial locations includes sample-to-sample variations, long-term analytical variations, and axial differences.

The variation in composition between the 4-, 8-, and 12- inch radial samples taken at a particular axial location includes sample-to-sample variations, analytical variations, and radial variations. By treating the samples obtained from the three radial locations as random samples taken from the same axial location and assuming no consistent radial effect, the radial component of variation provides the estimate of sampling and analytical uncertainty required to test the above hypothesis. The assumption of no radial effect was examined and appears to hold true. Also, a comparison of sampling and analytical relative standard deviations (RSDs) derived from previous experiments compared favorably with the (RSDs) from radial and analytical variations observed herein (see Table 3).

The statistical technique of analysis of variance was performed to meet the following objectives:

1) Determine whether shard sample composition is significantly different from core sample compositions, and if such differences are consistent from batch-to-batch. 
2) Determine whether there are significant batch-to-batch differences in composition.

3) Estimate short-term analytical and sample variations.

In the statistical analyses, the shard samples were treated as samples taken from other axial locations. The shards from the top of the canister immediately preceding the core drilled canister were treated as samples obtained below the bottom set of core samples. The shards from the top of the canister that was core drilled were treated as samples obtained above the top set of core samples. Thus, instead of seven axial locations, for the purposes of the statistical analyses, there were nine axial locations.

The primary statistical model used in the analyses was as follows:

$$
y_{i j k l}=u+B_{i}+H_{j}+B H_{i j}+R_{(i j) k}+E_{(j k k) !}
$$

where $y_{\mathrm{ijkl}}$ represents an observed elemental composition from the ith batch, $\mathrm{jth}$ axial height, $k$ th radial sample, and lth analysis,

$u$ represents the overall mean,

$B_{i}$ represents the effect of the $i$ th batch (average deviation from the overall mean,

$\mathrm{H}_{\mathrm{j}}$ represents the effect of the jth axial location averaged over all batches,

$\mathrm{BH}_{\mathrm{ij}}$ represents the interaction between the batch and height effects such that axial effects may not be the same for each batch,

$\mathrm{R}_{(\mathrm{ij)k})}$ represents the variation between radial samples from the ith batch and $\mathrm{jth}$ axial height,

$\mathrm{E}_{(\mathrm{j} \mathrm{k}) !}$ represents the variations between duplicate analyses on the $\mathrm{kth}$ radial sample from the jth axial height and ith batch. 
Several variations of this model were examined, including contrasting the analytical results between the shard samples at the top or bottom of the canister and the core samples. Examining linear and quadratic trends across the axial heights; and combining the $\mathrm{H}_{\mathrm{j}}$ and $\mathrm{BH}_{\mathrm{ij}}$ terms to form a hierarchical nested model to estimate variance components.

A preliminary analysis was conducted and the residuals were examined visually to identify possible outliers. Several outliers were identified and are shown in Table 1. An investigation into the causes for these outliers was inconclusive. Thus, statistical analyses were first conducted excluding outliers and then conducted again including outliers, to determine the effect of excluding the outliers. The major conclusions from each set of analyses did not differ significantly. Because it appeared that some of the outliers were erroneous even though the suspicion could not be validated, the results presented in this report are based on statistical analyses excluding the outliers shown in Table 1.

The preliminary analyses also showed that variations in elemental composition between analytical duplicates appeared to be similar for all batch, axial location, radial location, and combinations. Additionally, the variability between radial samples appeared to be similar across all batch/axial location combinations. Thus, the assumptions of homogeneity of variance required for a valid analysis of variance appear to be satisfied.

In all of the analyses, the $95 \%$ level of confidence was applied to determine statistical significance. In other words, a statistically significant difference implies that one can be at least $95 \%$ confident that the absolute value of the true difference between two average values is greater than 0 . 
TABLE 1. Outliers Deleted from. Satistical Analyses

\begin{tabular}{|l|l|l|}
\hline Log\# & Sample Name & Element \\
\hline 9001737 A\&B & WV-44A-37-12 a\&b & B, Li, Mn, Fe, Zr, Ni, Mo, Al \\
& & (Entire observations were deleted) \\
9001732 A\&B & WV-44A-47-8 a\&b & $\mathrm{Sr}$ \\
9001709 A\&B & WV-44A-86-8 a\&b & $\mathrm{Sr}$ \\
901710 A\&B & WV-66A-60-4 a\&b & $\mathrm{Sr}$ \\
9001616 A & WV44A-SH1 & K \\
9001617A & WV65A-SH2 & $\mathrm{Zn}, \mathrm{Ba}$ \\
9001633 A\&B & WV66A-47.5-8 a\&b & $\mathrm{Ti}$ \\
9001671 B & WV-44A-86-4 b & $\mathrm{S}, \mathrm{Mo}, \mathrm{Cu}, \mathrm{La}$ \\
9001672 A & WV-44a-61-8a & $\mathrm{S}, \mathrm{Mo}, \mathrm{Cu}, \mathrm{La}$ \\
9001632 B & WV-47A-24-4 b & $\mathrm{Zn}$ \\
9001627 B & WV-44A-74-8 b & $\mathrm{Si}$ \\
9001731 B & WV-47A-12-8 b & Ti \\
9001712 A & WV-66A-33-8 a & La, Li \\
9001614 A & WV-66A-sh2 & $\mathrm{Zn}$ \\
\hline
\end{tabular}




\section{Results of Statistical Analyses}

The major objective of this study was to determine whether shard samples are representative of the canister contents. The statistical analyses revealed that for the majority of elemental oxides, there were no significant consistent differences between the shard average elemental concentrations and the core sample elemental concentrations. The average concentrations across each batch and axial location for each elemental oxide are shown in Figures A1 through A23.

Significant differences between shard concentrations and core concentrations were found for $\mathrm{Cr}, \mathrm{Ni}, \mathrm{Zn}$, and $\mathrm{Ba}$. The differences observed for $\mathrm{Ba}$ and $\mathrm{Zn}$ were expected, because they were used as tracer elements in the SF-12 run. An explanation for the $\mathrm{Cr}$ and Ni differences observed is less obvious. However, the average weight percents for $\mathrm{Cr}$ and $\mathrm{Ni}$ are sufficiently small ( $<0.25 \mathrm{wt} . \%)$ that the majority of the uncertainty is due to analytical variation. Thus, this observed difference between core sample and shard sample concentrations for $\mathrm{Cr}$ and $\mathrm{Ni}$ could be an artifact of a problem in the analytical laboratory. Moreover, $\mathrm{Cr}$ and $\mathrm{Ni}$ are minor constituents and will not factor into a determination of waste product acceptability, nor will WVNS be required to report minor constituents with weight percents less than $0.5 \%$ (see Waste Acceptance Preliminary Specification 1.1.2).

Tests were also conducted to determine whether any linear or quadratic trends could be detected along the axial heights within each canister. With the exception of the tracer elements $\mathrm{Ba}$ and $\mathrm{Zn}$ ), no significant consistent linear or quadratic trends were observed. This suggests that the differences between batch compositions were sufficiently small that any linearity was masked by sampling and analytical variations.

The statistical analyses revealed significant batch-to-batch differences for many of the elemental constituents. The average compositions for each batch are shown in Table 2. Although the batch-to-batch variation is statistically significant for many constituents, the differences between batch elemental weight percents are quite small. The ability to detect small differences in composition between batches is a function of the many samples obtained from each batch. This analysis provides an estimate of the expected batch-to-batch variation (process variation) when the process is being controlled similarly to the SF-12 run. This estimate is based 
TABLE 2. Comparision of Elemental Oxide Weight Percent Analyses for Each Batch

\begin{tabular}{|c|c|c|c|c|}
\hline Element & Batch 1 & Batch 2 & Batch 3 & Significance ${ }^{(a)}$ \\
\hline $\mathrm{Si}$ & 43.54 & 43.14 & 42.29 & $\mathrm{Y}$ \\
\hline $\mathrm{Fe}$ & 11.75 & 11.96 & 12.32 & $\mathrm{Y}$ \\
\hline $\mathrm{Na}$ & 11.54 & 11.69 & 11.84 & $\mathrm{Y}$ \\
\hline B. & 10.50 & 10.64 & 10.63 & $\mathrm{Y}$ \\
\hline $\mathrm{Al}$ & 6.71 & 6.48 & 6.57 & $\mathrm{Y}$ \\
\hline $\mathrm{K}$ & 3.69 & 3.75 & 3.73 & $\mathrm{~N}$ \\
\hline $\mathrm{Li}$ & 3.31 & 3.32 & 3.33 & $\mathrm{~N}$ \\
\hline $\mathrm{P}$ & 2.56 & 2.59 & 2.60 & $Y$ \\
\hline $\mathrm{Zr}$ & 2.10 & 2.25 & 2.34 & $\mathrm{Y}$ \\
\hline $\mathrm{Mn}$ & 0.97 & 0.98 & 1.00 & $Y$ \\
\hline $\mathrm{Ti}$ & 0.82 & 0.83 & 0.84 & $\mathrm{Y}$ \\
\hline $\mathrm{Mg}$ & 0.87 & 0.80 & 0.83 & $N$ \\
\hline $\mathrm{Ca}$ & 0.46 & 0.45 & 0.47 & $\dot{N}$ \\
\hline $\mathrm{Zn}$ & 0.37 & 0.21 & 0.24 & $Y$ \\
\hline $\mathrm{Ni}$ & 0.23 & 0.22 & 0.23 & $\mathrm{~N}$ \\
\hline $\mathrm{Ba}$ & 0.09 & 0.21 & 0.19 & $\mathrm{Y}$ \\
\hline$S$ & 0.14 & 0.14 & 0.17 & $\mathrm{~N}$ \\
\hline $\mathrm{Cr}$ & 0.10 & 0.12 & 0.11 & $Y$ \\
\hline $\mathrm{Cs}$ & 0.092 & 0.095 & 0.103 & $Y$ \\
\hline $\mathrm{Cu}$ & 0.052 & 0.056 & 0.060 & $\mathrm{Y}$ \\
\hline Mo & 0.051 & 0.049 & 0.050 & $\mathrm{Y}$ \\
\hline $\mathrm{Sr}$ & 0.029 & 0.030 & 0.050 & $\mathrm{Y}$ \\
\hline $\mathrm{La}$ & 0.021 & 0.017 & 0.022 & $\mathrm{~N}$ \\
\hline
\end{tabular}

(a) Y represents that one can be $95 \%$ confident that the true batch averages were significantly differenct. $\mathrm{N}$ means that no significant differences were detected at the $95 \%$ confidence levels. 
on only three batches and, therefore, is not very precise; but it, nevertheless, provides some estimate of process variation.

At some axial locations, the weight percent averages for some elements differed significantly from the averages at other axial locations within a canister. These differences were not consistent 'across different elements nor across different canisters. In conducting numerous statistical tests; it is to be expected that some tests will reveal significant differences when, in fact, the true averages are the same. Such isolated differences could be an artifact of the number of statistical tests performed. These isolated differences are usually a result of significant variability among average concentrations at various axial heights and are manifest in larger axial height variance components, as discussed below.

Finally, an analysis was conducted to isolate and estimate the portions of total variation due to analytical, sampling, axial, and batch variations. The relative standard deviations for each component of variance are reported in Table 3. Although some systematic sampling occurred, if we assume that the samples are random, estimation of these components of variance is appropriate. These estimates are required to determine the appropriate frequency and procedure for sampling the canisters to meet waste form qualification objectives.

For the major constituents ( $w t \%>0.5 \%$ ), the within-canister relative standard deviations are less than 3.5\%, with the exception of $\mathrm{Mg}(\mathrm{RSD}=14 \%)$ and $\mathrm{K}(\mathrm{RSD}=5.3 \%)$. For the minor constituents ( $w$ t $\%<0.5 \%$ ) the within-canister RSD ranges from $5 \%$ to $68 \%$. The batch-to-batch RSDs for the major constituents were less than $3.5 \%$ with the exception of $\mathrm{Zr}(\mathrm{RSD}=5.4 \%)$. The batch-to-batch RSDs for the minor constituents ranged from $0.0 \%$ to $7.8 \%$, excluding the tracer elements. Figure 4 shows the total relative standard deviations for each element and illustrates the portion of the total RSD due to within-canister variations including sampling and analytical variations and due to batch variations.

The analytical RSDs were very small and reflect only the short-term analytical variations. The variations between the different radial samples taken from a particular canister and axial location reflect radial variations as well as sampling and long-term analytical variations. As shown in Table 4, these RSDs are similar to combined sampling and analytical RSDs observed from a previous study (Pulsipher 1989). This suggests that the pure radial variations (excluding sampling and analytical variations) are probably negligible. 
TABLE 3. Variance Components in Terms of Relative Standard Deviations with Sampling and Analytical Relative Standard Deviations (RSD) Compared with Previous Estimates

\begin{tabular}{|c|c|c|c|c|c|c|c|c|c|c|}
\hline 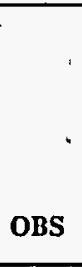 & $\begin{array}{c}\text { ELEMENTA } \\
\text { L OXIDE }\end{array}$ & MEAN & $\begin{array}{c}\text { SIIORT- } \\
\text { TERM } \\
\text { ANALYTIC } \\
\text { AL RSD }\end{array}$ & $\begin{array}{l}\text { SAMPLING } \\
\text { PSD } \\
\end{array}$ & $\begin{array}{c}\text { AXIAL } \\
\text { HEIGITT } \\
\text { RSD }\end{array}$ & BATCII RSD & $\begin{array}{c}\text { WITHIN }^{(B)} \\
\text { CANISTER }^{-} \\
\text {RSD } \\
\end{array}$ & TOTAL RSD & $\begin{array}{c}\text { COMBINED } \\
\text { SAMPLING } \\
\text { AND } \\
\text { ANALYTIC } \\
\text { AL RSD }\end{array}$ & $\begin{array}{l}\text { PREVIOUS'C } \\
\text { 'RSD } \\
\text { ESTIMATE }\end{array}$ \\
\hline 1 & $\mathrm{Si}$ & 42.97 & 0.4 & 1.9 & 0.0 & 1.4 & 2.0 & 2.4 & 2.0 & 1.1 \\
\hline 2 & $\mathrm{Fe}$ & 12.01 & 0.5 & 1.5 & 0.7 & 2.3 & 1.8 & 2.9 & 1.6 & 1.3 \\
\hline 3 & $\mathrm{Na}$ & 11.70 & 0.5 & 1.5 & 0.2 & 1.2 & 1.6 & 2.0 & 1.6 & 2.8 \\
\hline 4 & B & 10.59 & 0.5 & 1.8 & 1.0 & 0.5 & 1.9 & 2.0 & 1.7 & 1.9 \\
\hline 5 & $\mathrm{Al}$ & 6.585 & 1.6 & 2.8 & 1.2 & 1.7 & 3.4 & 3.8 & 3.2 & 5.1 \\
\hline 6 & $\mathrm{~K}$ & 3.742 & 2.3 & 4.2 & 2.3 & 0.0 & 5.3 & 5.3 & 4.8 & 11.3 \\
\hline 7 & $\mathrm{Li}$ & 3.325 & 0.5 & 2.0 & 0.6 & 0.0 & 2.1 & 2.1 & 2.0 & 2.8 \\
\hline 8 & $\mathrm{P}$ & 2.586 & 0.9 & 1.3 & 0.7 & 0.9 & $1.7^{\circ}$ & 1.9 & 1.6 & 3.9 \\
\hline 9 & $\mathrm{Zr}$ & 2.232 & 0.6 & 1.9 & 0.8 & 5.4 & 2.0 & 5.8 & 2.0 & 1.2 \\
\hline 10 & Wn & 0.985 & 0.5 & 1.3 & 0.8 & 1.3 & 1.5 & 2.0 & 1.3 & 2.5 \\
\hline 11 & $\mathrm{Ti}$ & 0.830 & 0.8 & 2.5 & 0.0 & 0.9 & 2.6 & 2.3 & 2.6 & 1.8 \\
\hline 12 & $\mathrm{Mg}$ & 0.826 & 6.2 & 10.7 & 6.5 & 3.2 & 14.0 & 14.3 & 12.4 & 11.2 \\
\hline 13 & $\mathrm{Ca}$ & 0.463 & 5.8 & 10.1 & 5.1 & 0.0 & 12.7 & 12.7 & 11.6 & 30.9 \\
\hline 14 & $\mathrm{Zn}$ & 0.274 & 0.8 & 3.4 & $9.6^{(c)}$ & 30.2 & 10.2 & 31.9 & 3.5 & . \\
\hline 15 & $\mathrm{Ni}$ & 0.226 & 2.5 & 5.9 & $3.7^{(d)}$ & 0.0 & 7.4 & 7.4 & 6.5 & 8.3 \\
\hline 16 & $\mathrm{Ba}$ & 0.161 & 2.8 & 6.0 & $11.4^{(0)}$ & 38.5 & 13.2 & 40.7 & 6.6 & 13.5 \\
\hline
\end{tabular}




\begin{tabular}{|c|c|c|c|c|c|c|c|}
\hline 昜 & $\stackrel{b}{m}$ & $\begin{array}{l}\stackrel{0}{\dot{v}} \\
\text {. }\end{array}$ & $\begin{array}{l}\infty \\
\stackrel{\infty}{9}\end{array}$ & & & $\ddot{n}$ & \\
\hline 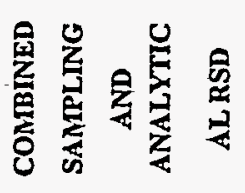 & $\stackrel{m}{a}$ & $\tilde{\overbrace{}}$ & $\underset{\substack{\infty \\
+}}{ }$ & $\stackrel{\infty}{\infty}$ & m. & $\stackrel{\infty}{i}$ & Oे \\
\hline 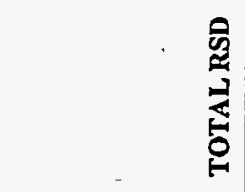 & $\stackrel{n}{6}$ & $\ddot{\vec{n}}$ & 芒 & $\stackrel{\infty}{\Xi}$ & $\stackrel{0}{0}$ & สู & 守 \\
\hline 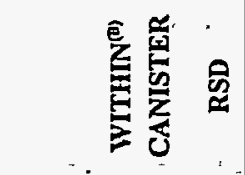 & $\frac{n}{6}$ & $\stackrel{\vec{Z}}{\grave{N}}$ & $\stackrel{\infty}{+}$ & & $\underset{\infty}{m}$ & $\therefore$ & $\ddot{g}$ \\
\hline 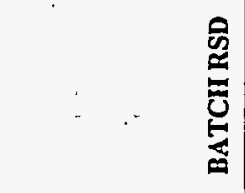 & $\stackrel{\circ}{\circ}$ & $\bar{\pi}$ & $\overrightarrow{i n}$ & $\stackrel{\infty}{\sim}$ & $\stackrel{i}{i}$ & $\stackrel{-}{\circ}$ & $\overline{6}$ \\
\hline 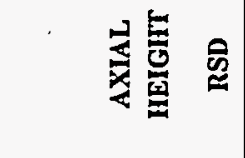 & 응 & $\begin{array}{l}\overline{0} \\
\stackrel{0}{0} \\
\end{array}$ & $\stackrel{0}{\circ}$ & $\stackrel{\circ}{\circ}$ & $\therefore$ & $q$ & $\therefore$ \\
\hline 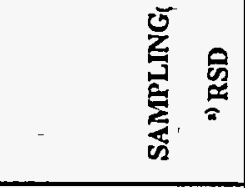 & iे & in & $\stackrel{m}{m}$ & $\stackrel{m}{?}$ & in & ? & @) \\
\hline 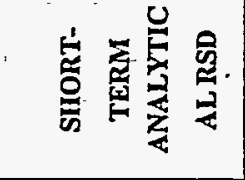 & స్ర & $\vec{m}$ & $\stackrel{\circ}{\dot{m}}$ & గี & ָુ & $\stackrel{m}{\forall}$ & m: \\
\hline$\frac{z}{x^{\prime}}$ & $\underset{0}{\mathcal{Z}}$ & $\begin{array}{c}5 \\
0 \\
0\end{array}$ & $\begin{array}{l}0 \\
0 \\
0 \\
0\end{array}$ & $\begin{array}{l}0 \\
: \\
0 \\
0\end{array}$ & $\begin{array}{l}\stackrel{\circ}{0} \\
\text { O. }\end{array}$ & 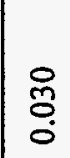 & $\bar{\sigma}$ \\
\hline 意睍 & $\infty$ & ช̆ & $y^{2}$ & $\overline{0}$ & $\stackrel{\circ}{\Sigma}$ & मे & $\stackrel{\Xi}{9}$ \\
\hline 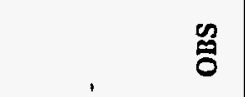 & 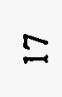 & $\stackrel{\infty}{\rightarrow}$ & 2 & సి & $\bar{N}$ & $\approx$ & $\tilde{\sim}$ \\
\hline
\end{tabular}




\section{Conclusions and Recommendations}

Based on the statistical analyses, the shard samples appear to be representative of the canister contents for all elemental constituents except $\mathrm{Ni}$ and $\mathrm{Cr}$. The $\mathrm{Ni}$ and $\mathrm{Cr}$ are minor constituents and are not expected to affect waste product acceptability nor is there a requirement to report the elemental concentration for these minor constituents.

No trends within each canister were detectable with the exception of the elements used for tracer studies in the SF-12 run. The fact that trends were observed for the two tracer elements lends credibility to the statistical analyses. No trends suggests that shard samples can be considered as representative samples of the canister contents.

Estimates of variation between batches, axial locations, radial locations, and duplicate analyses were obtained. The within-canister relative standard deviations for the major elemental constituents were relatively small except for $\mathrm{Mg}$ and, perhaps, $\mathrm{K}$. Control during the SF-12 run maintained the batch-to-batch relative standard deviations to less than $3.5 \%$ for the major constituents with $\mathrm{Zr}$ as an exception. These estimates will prove valuable in determining the frequency and number of glass samples required to meet waste form qualification objectives.

In summary, assuming that process controls employed during the SF-12 run are representative of those imposed during future operations of the WVNS melter process (i.e., batch-to-batch variations in composition are controlled to acceptable levels), shard samples obtained from the top of the canisters will be representative of the canister contents. However, estimates derived herein

for within-canister variability should be incorporated into uncertainty estimates associated with reported canister compositions derived from shard samples. 


\section{References}

Jain, V.J. February 1990. Test Request-Sampling Plan for Shard and Canister Glass Correlation Tests, WVNS-TRQ-021, West Valley Nuclear Services, West Valley, New York.

Jain, V.J. April 1990. Test Procedure - Sampling Plan for shard and Canister Glass Correlation Tests, WVNS-TRP-021, West Valley Nuclear Services, West Valley, New York.

Pulsipher, B.A. and D.L. Eggett. July 1989. Accuracy and Precision of Glass Sample Analyses, Letter Report to West Valley Nuclear Services, WVSP-89-108. Pacific Northwest Laboratory, Richland, Washington. 


\section{APPENDIX A}

\section{PLOTS OF AXIAL HEIGHT MEANS FOR EACH BATCH}


AXIAL HEIGHT MEANS BY BATCHES

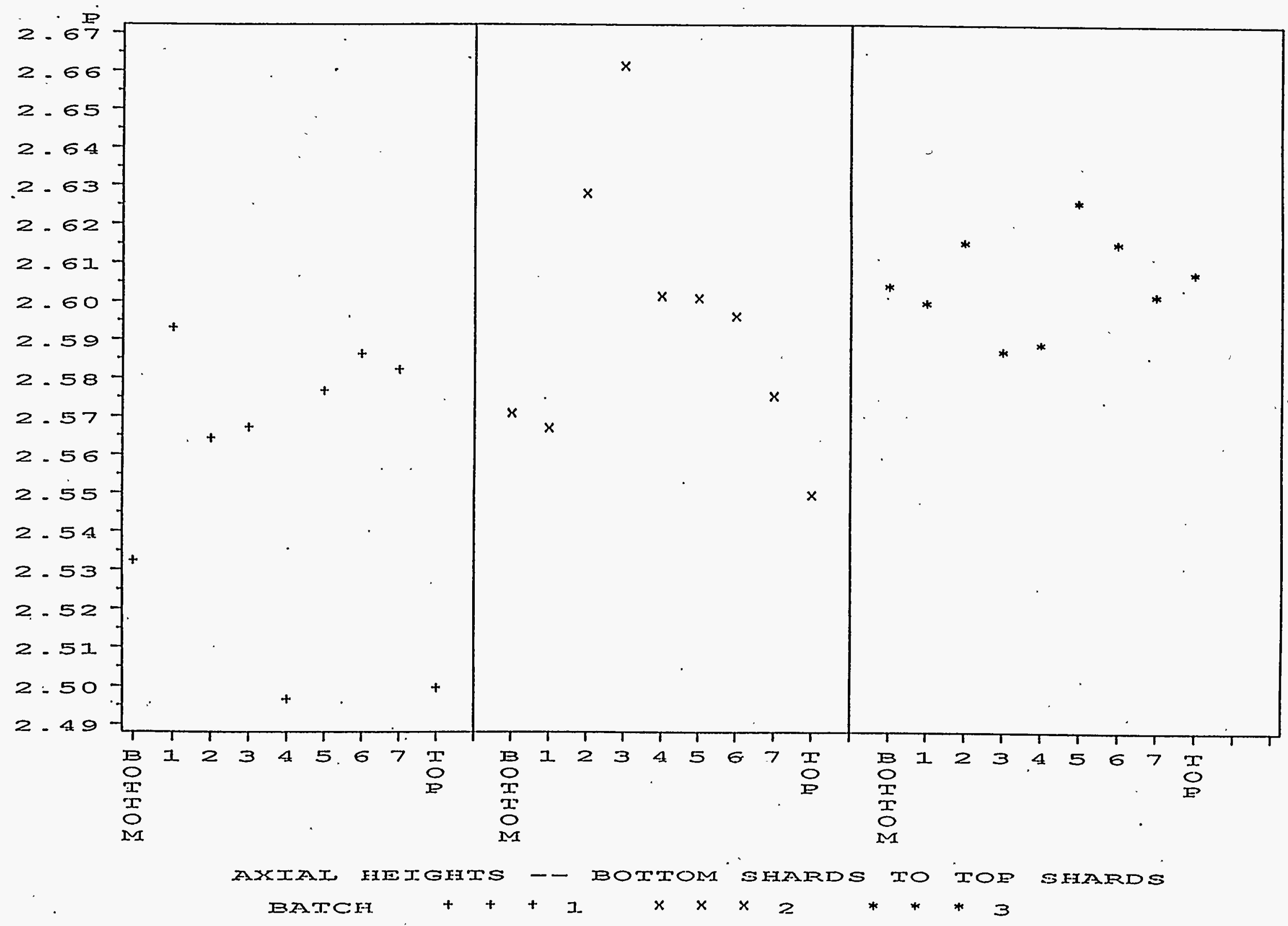




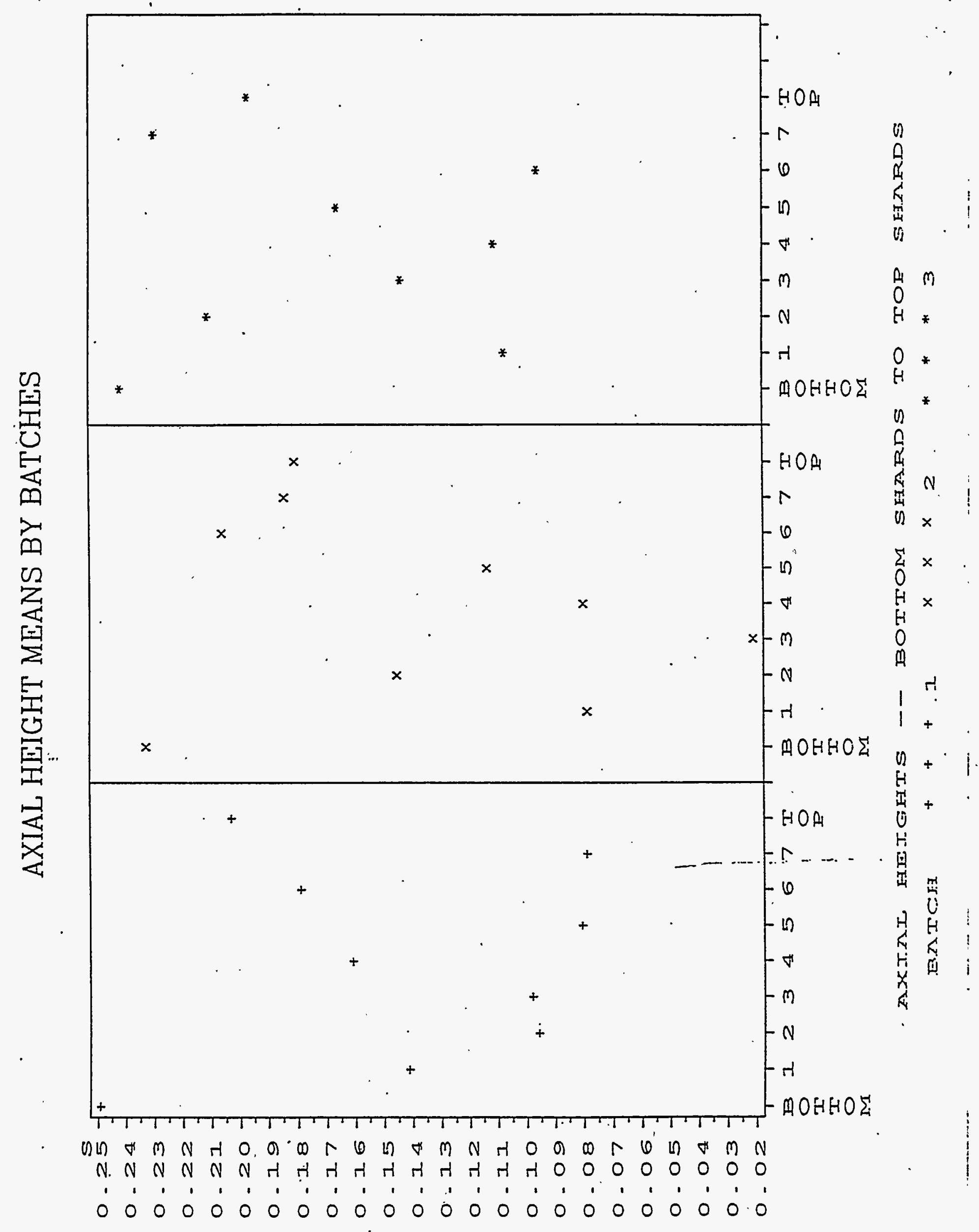




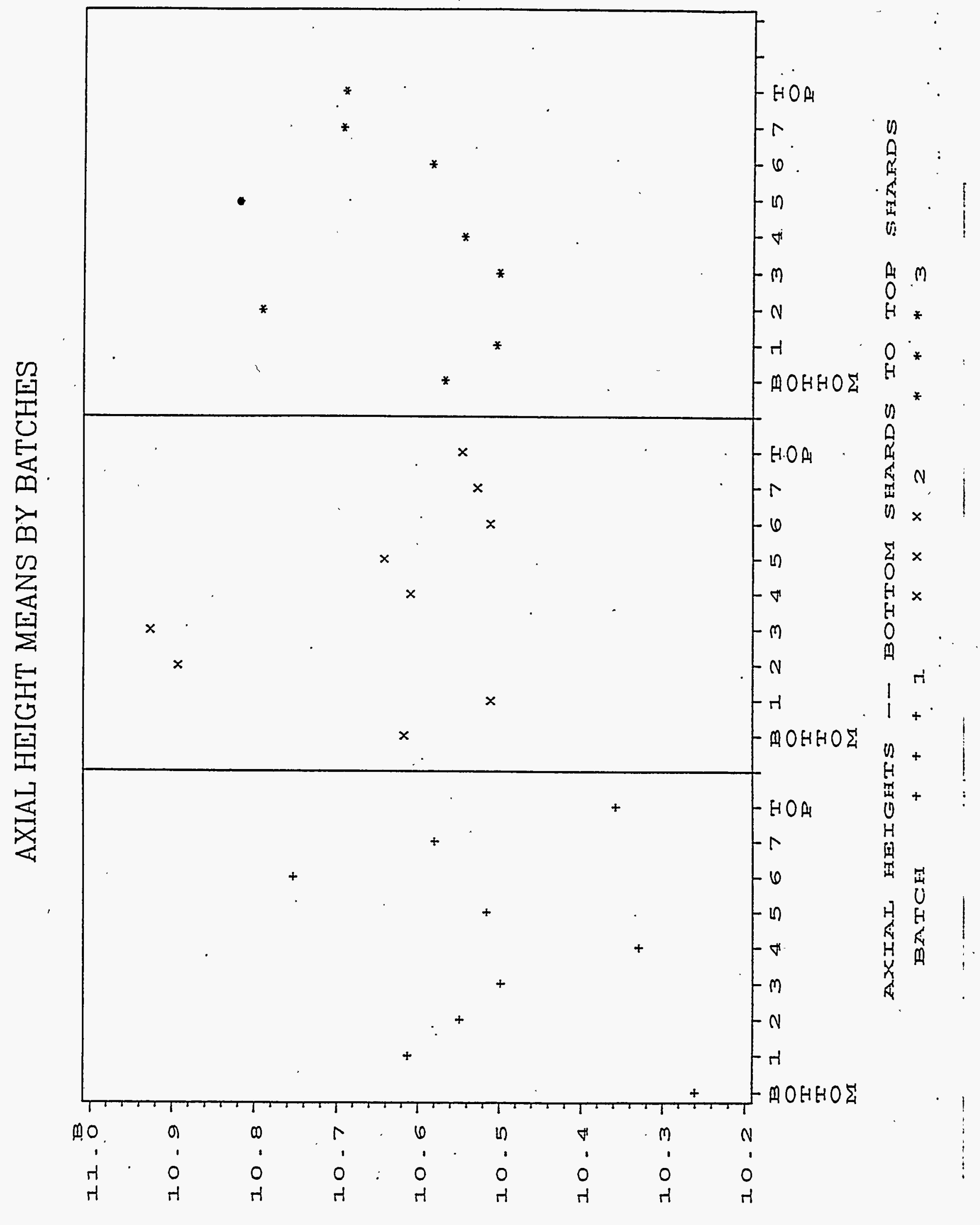




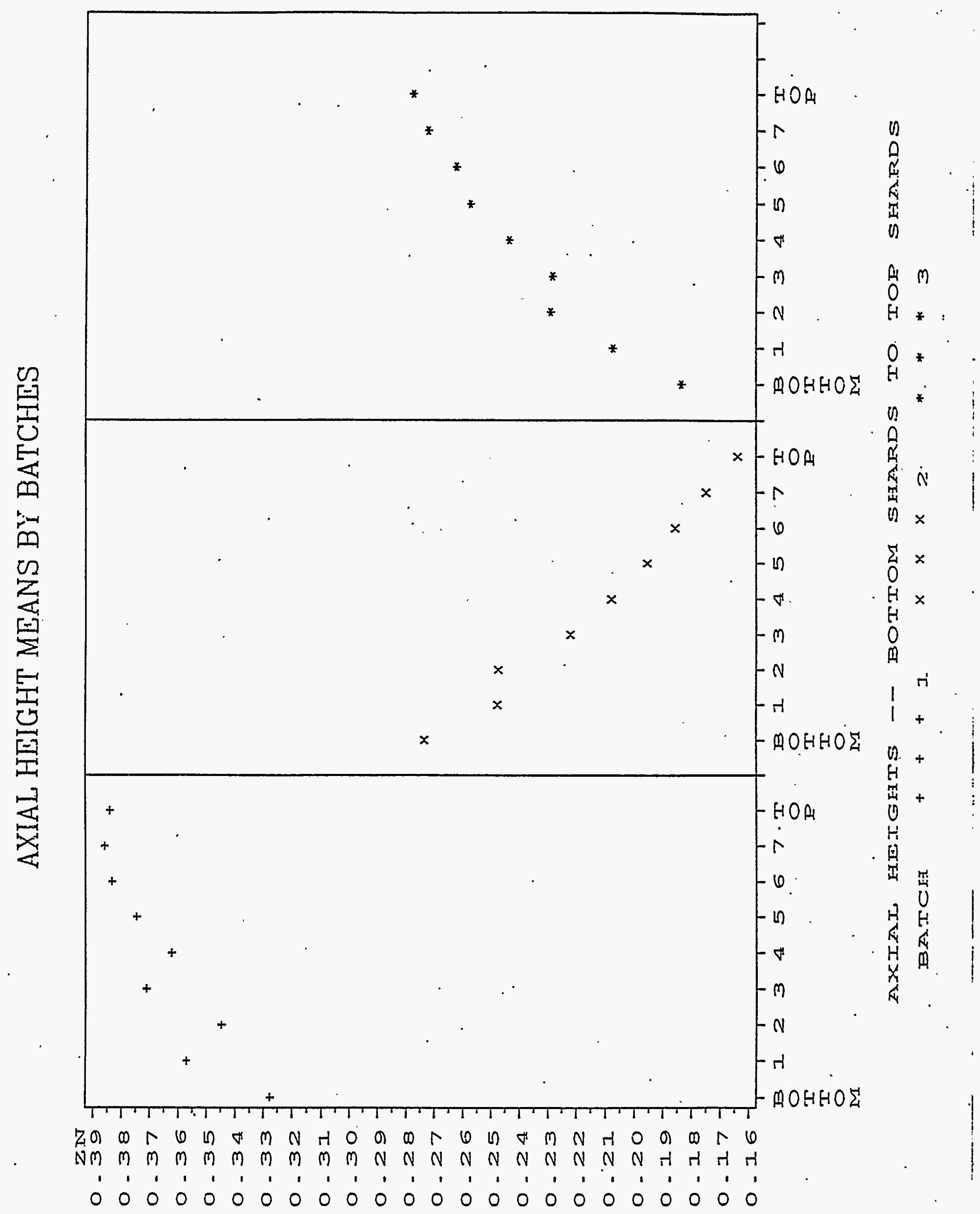




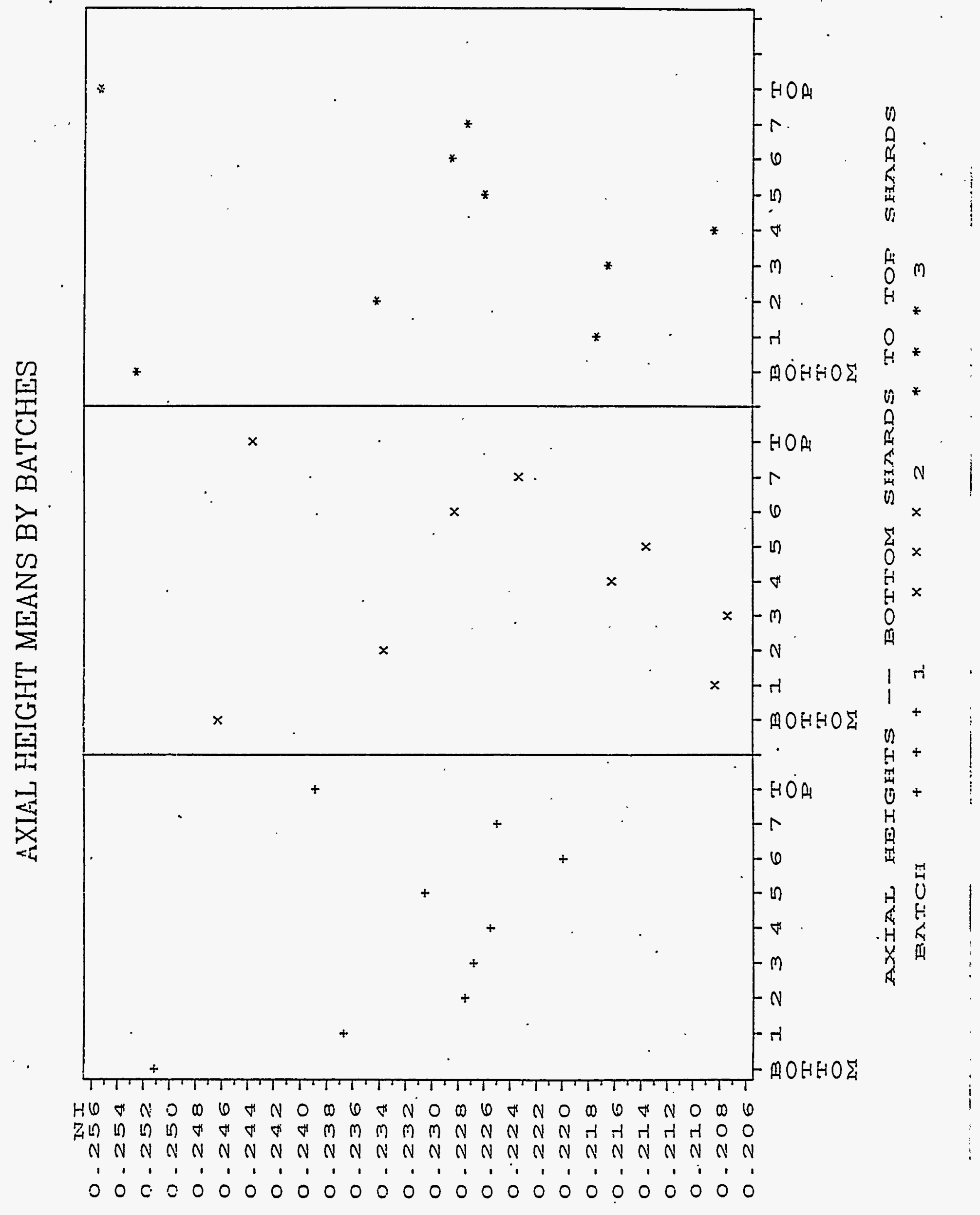




\section{AXIAL HEIGHT MEANS BY BATCHES}

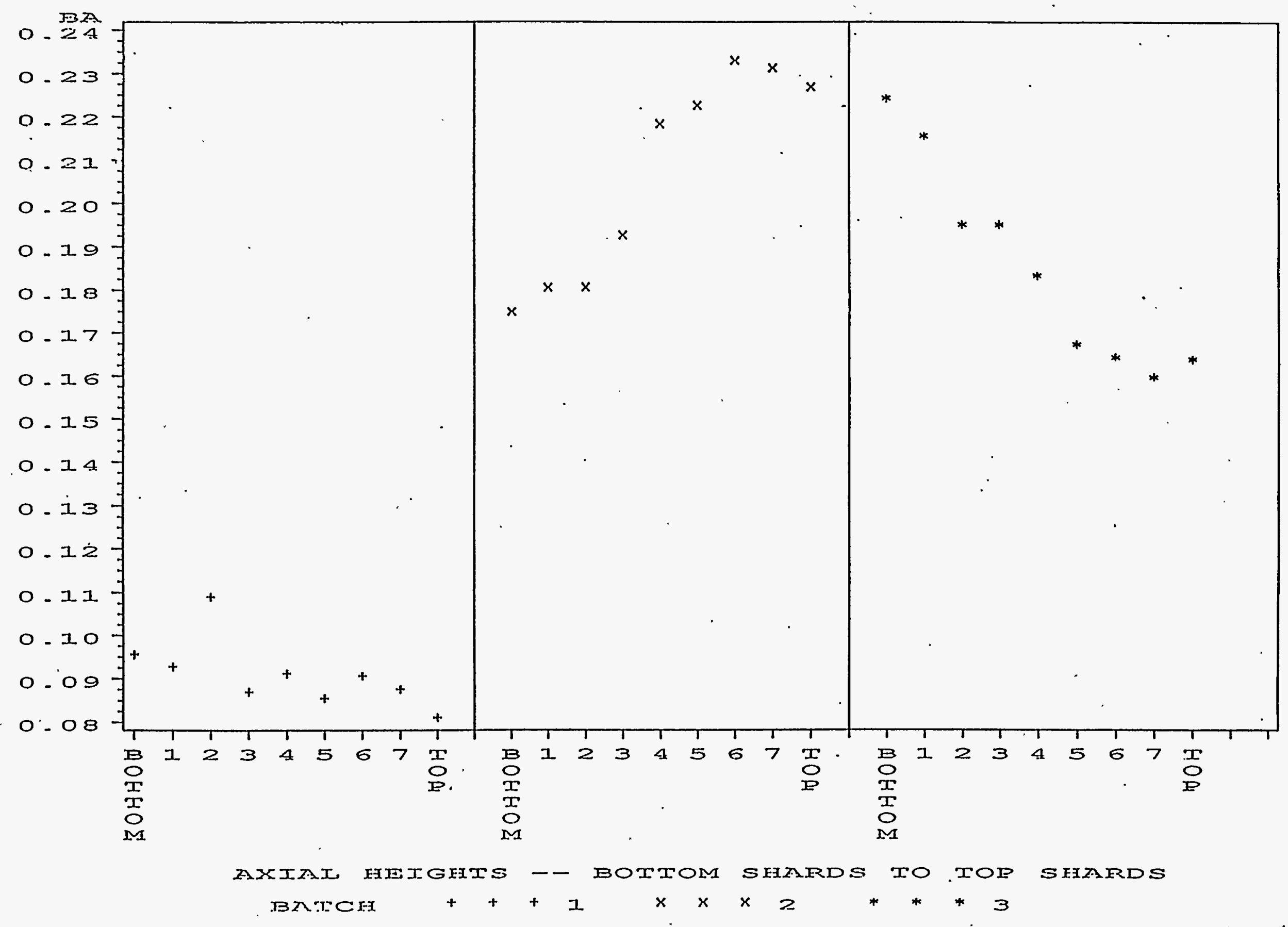




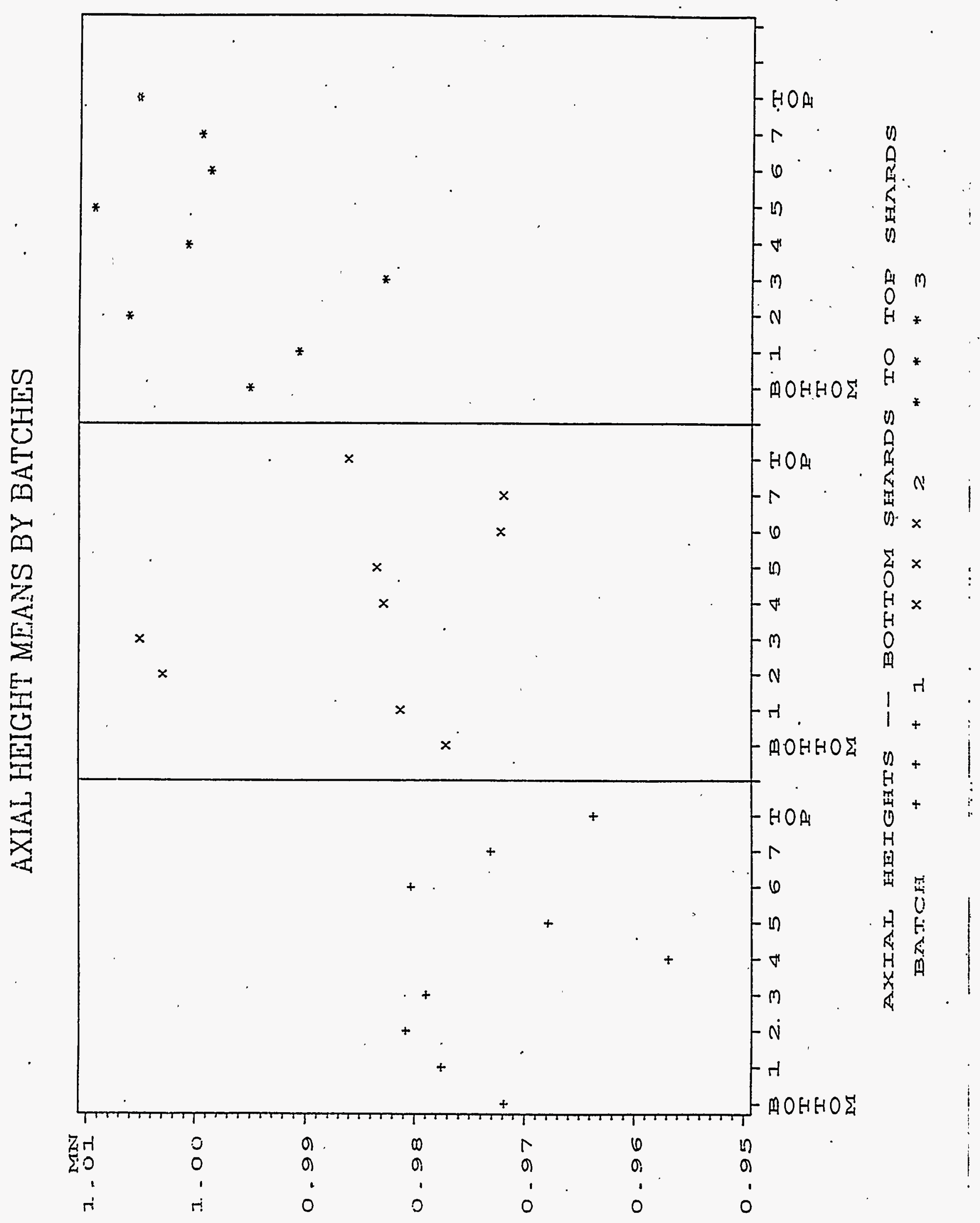




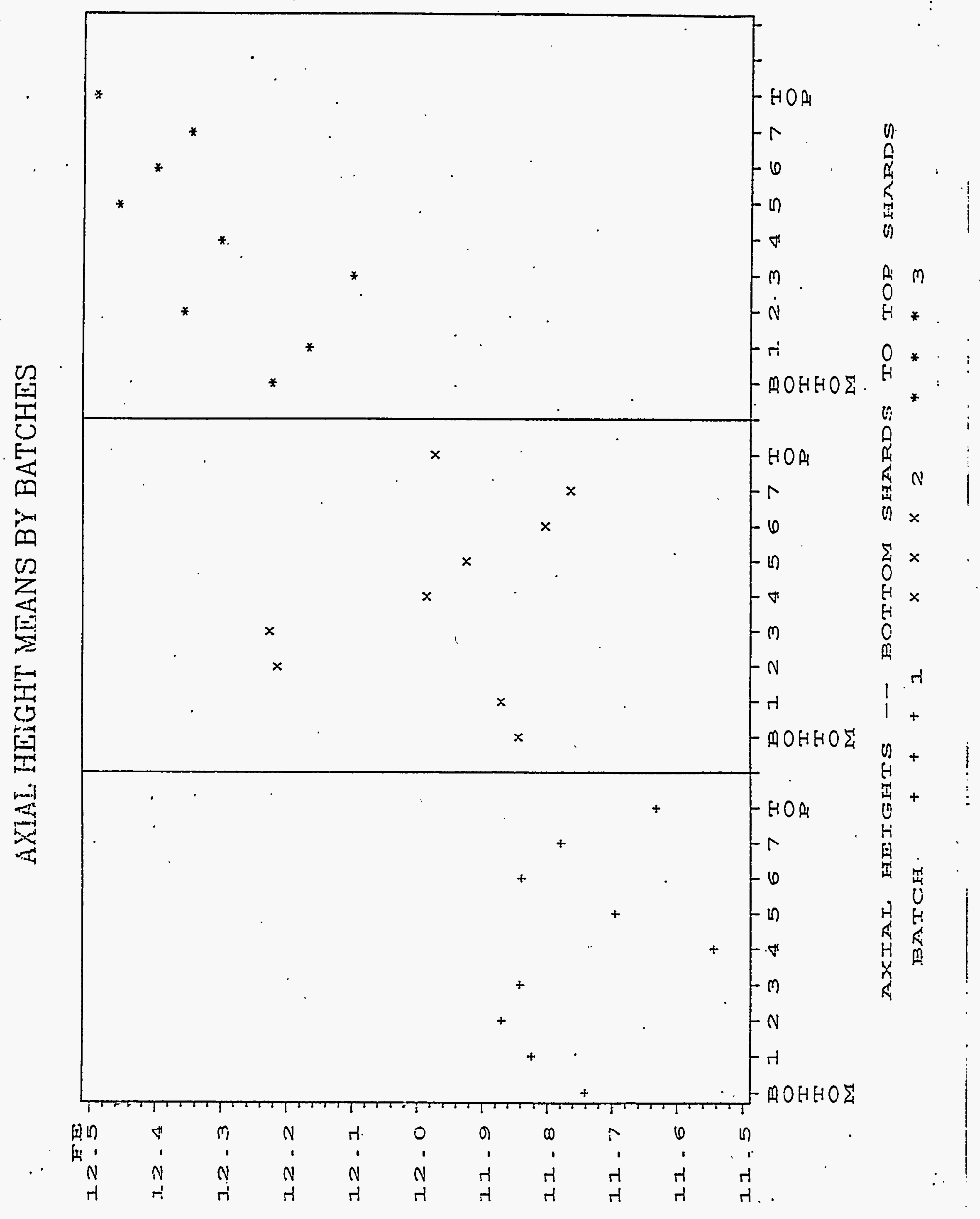




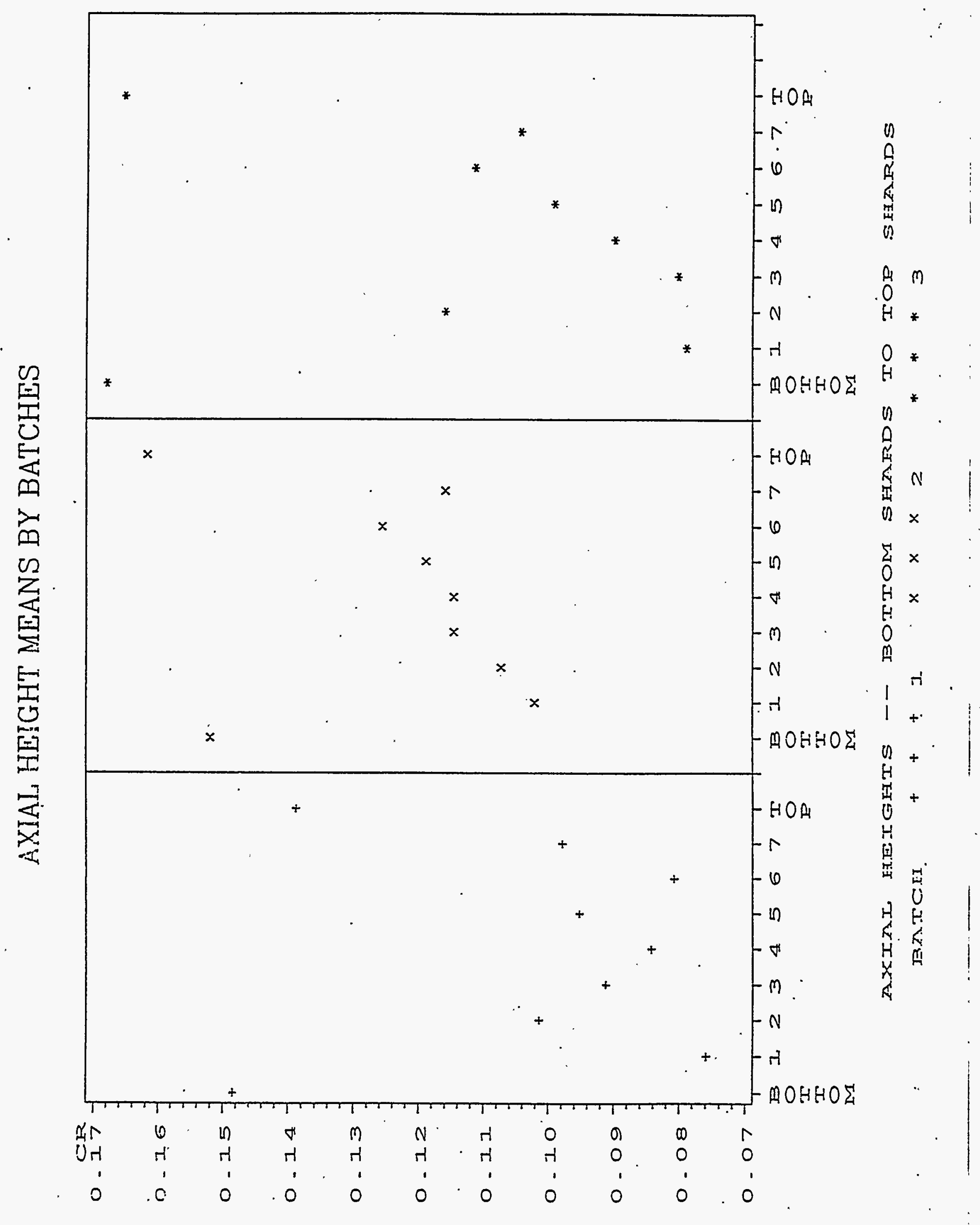




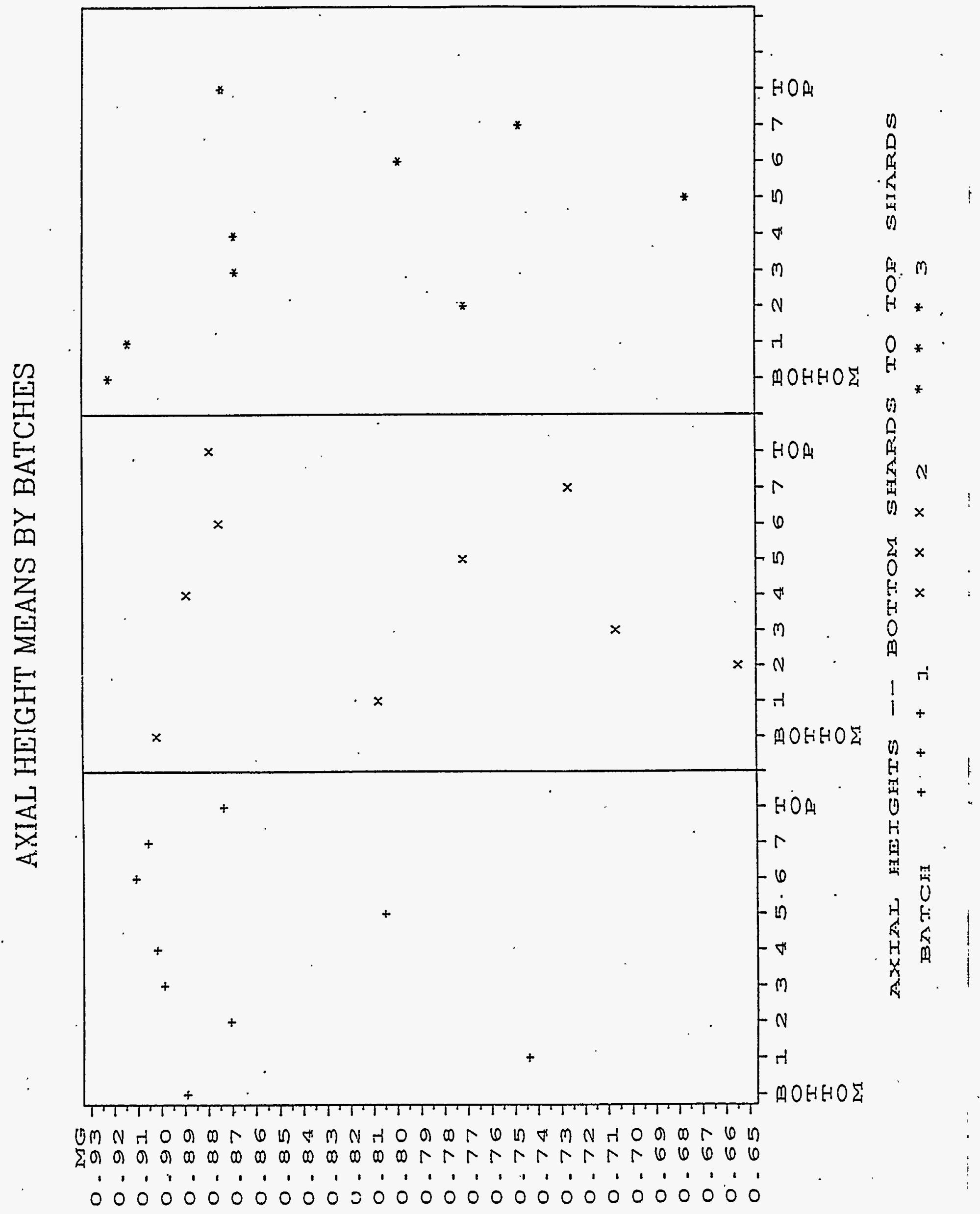




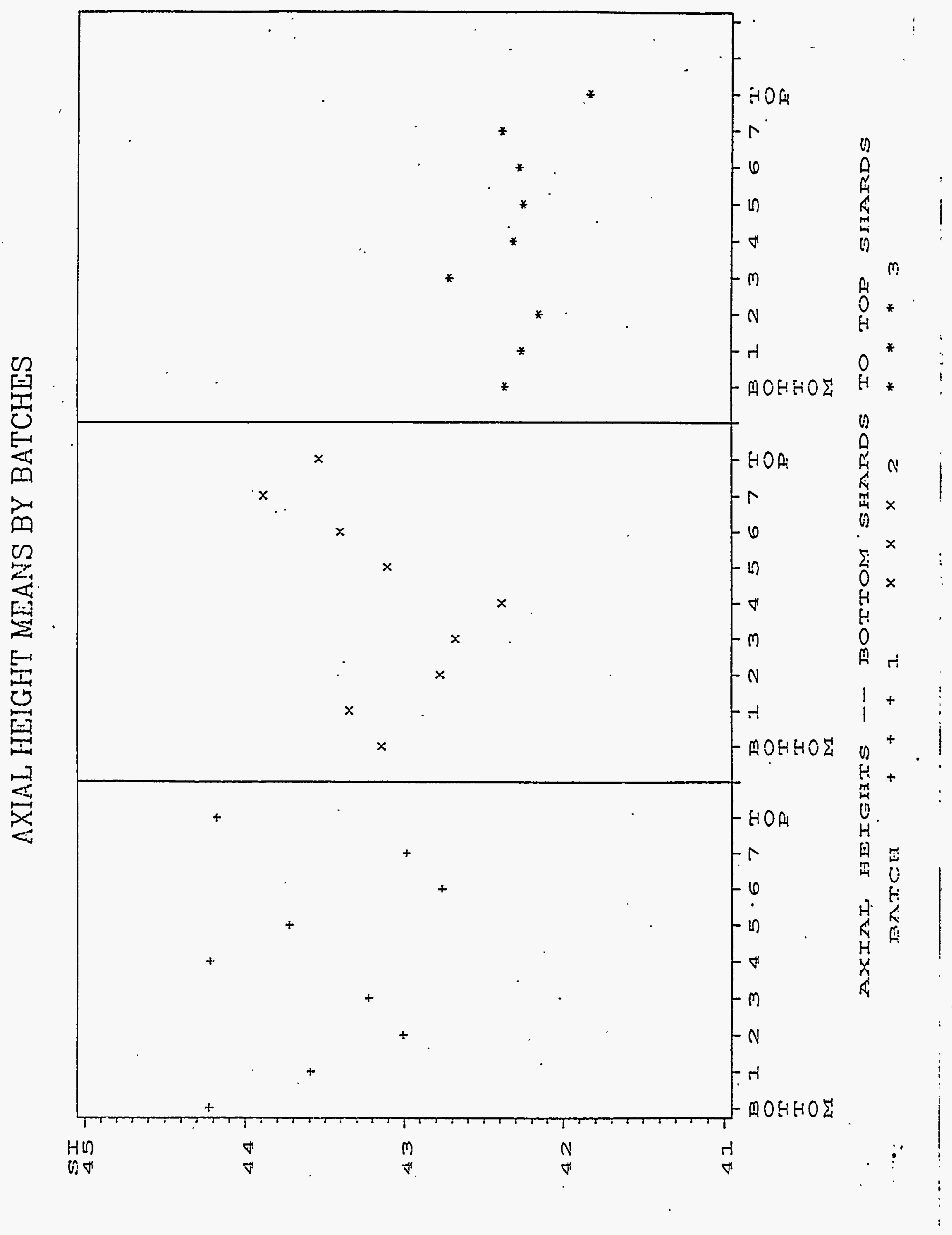




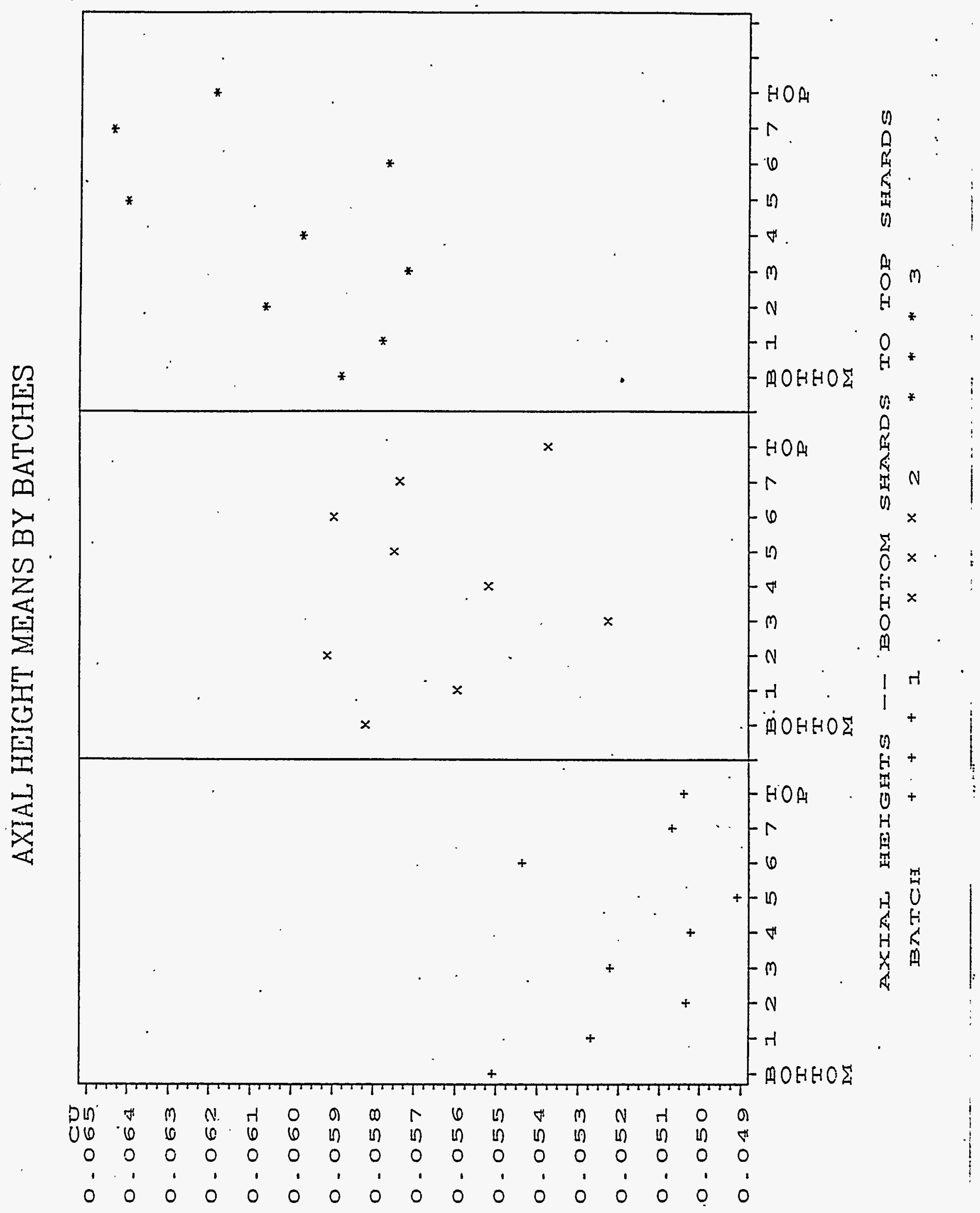




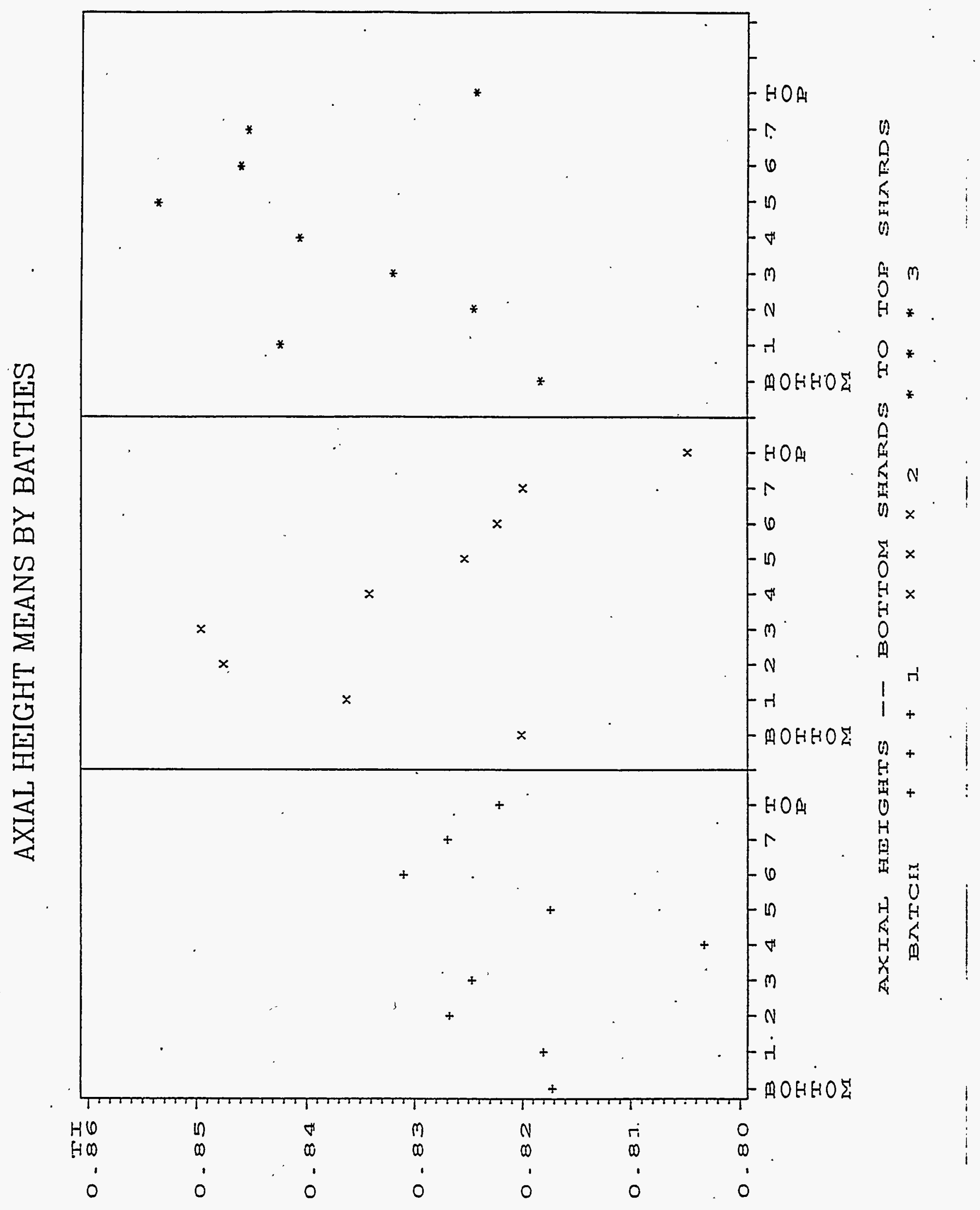




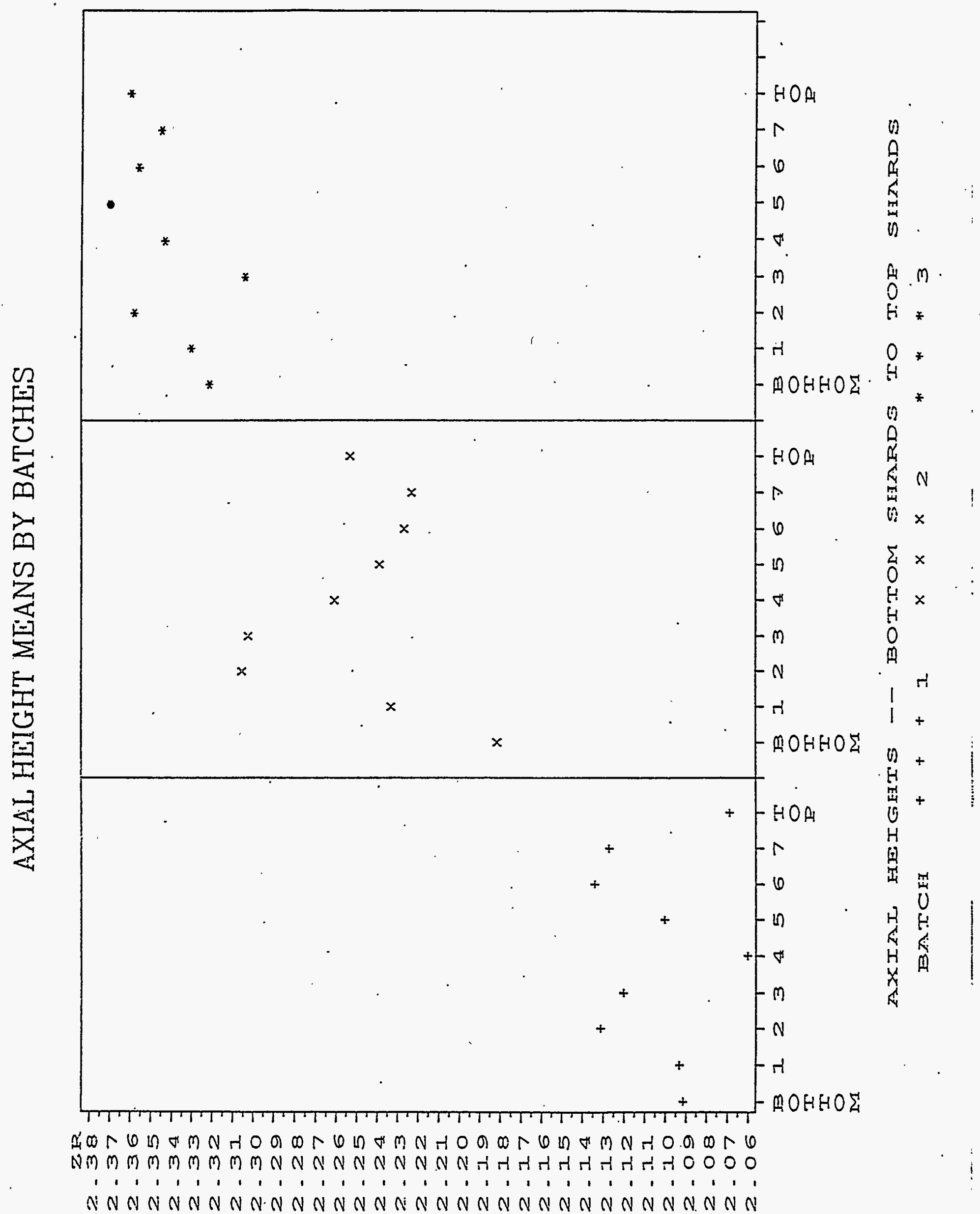

$N N N N N N N N N N N N N N N N N N N N N N N N N N N N N N N N N$ 


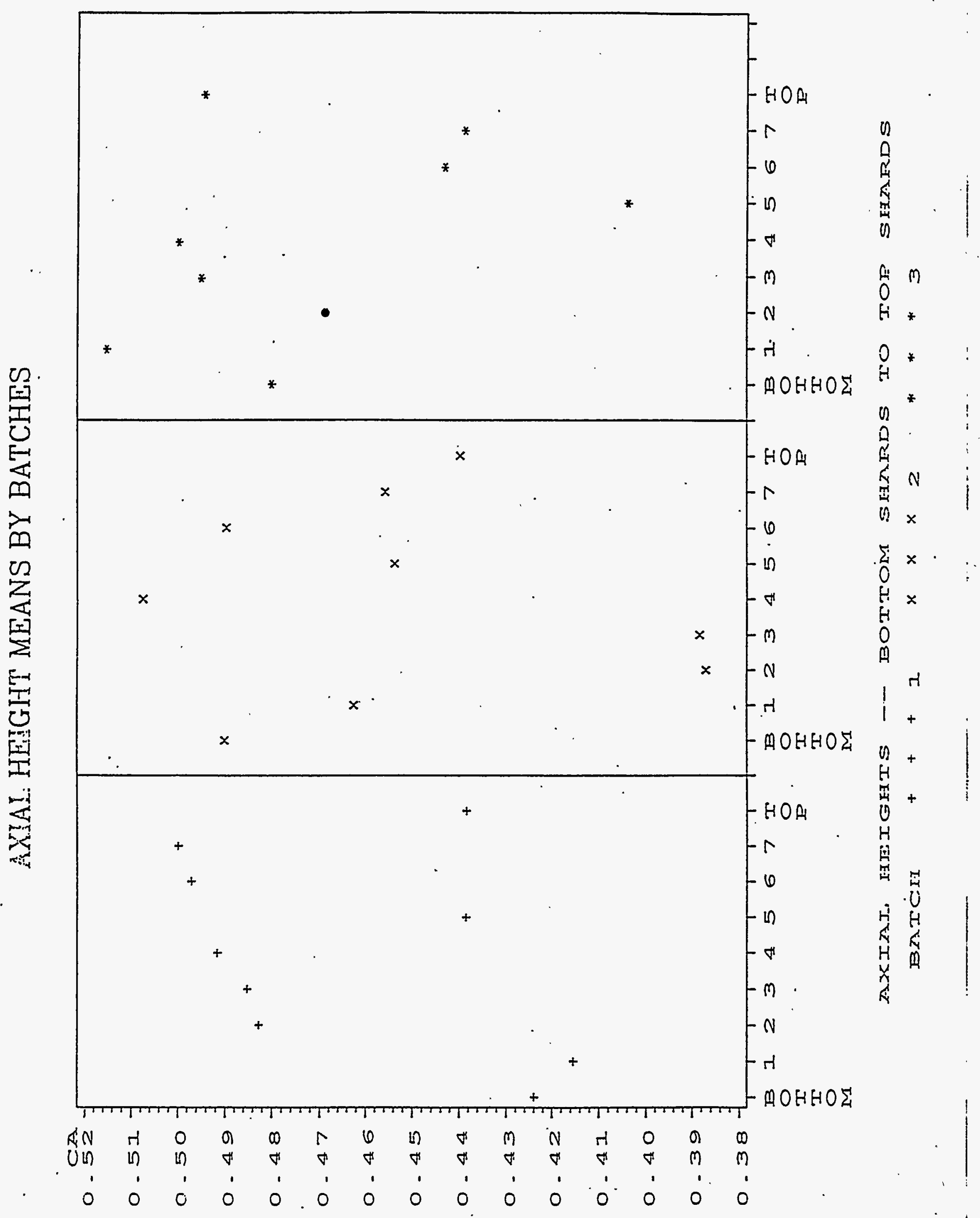




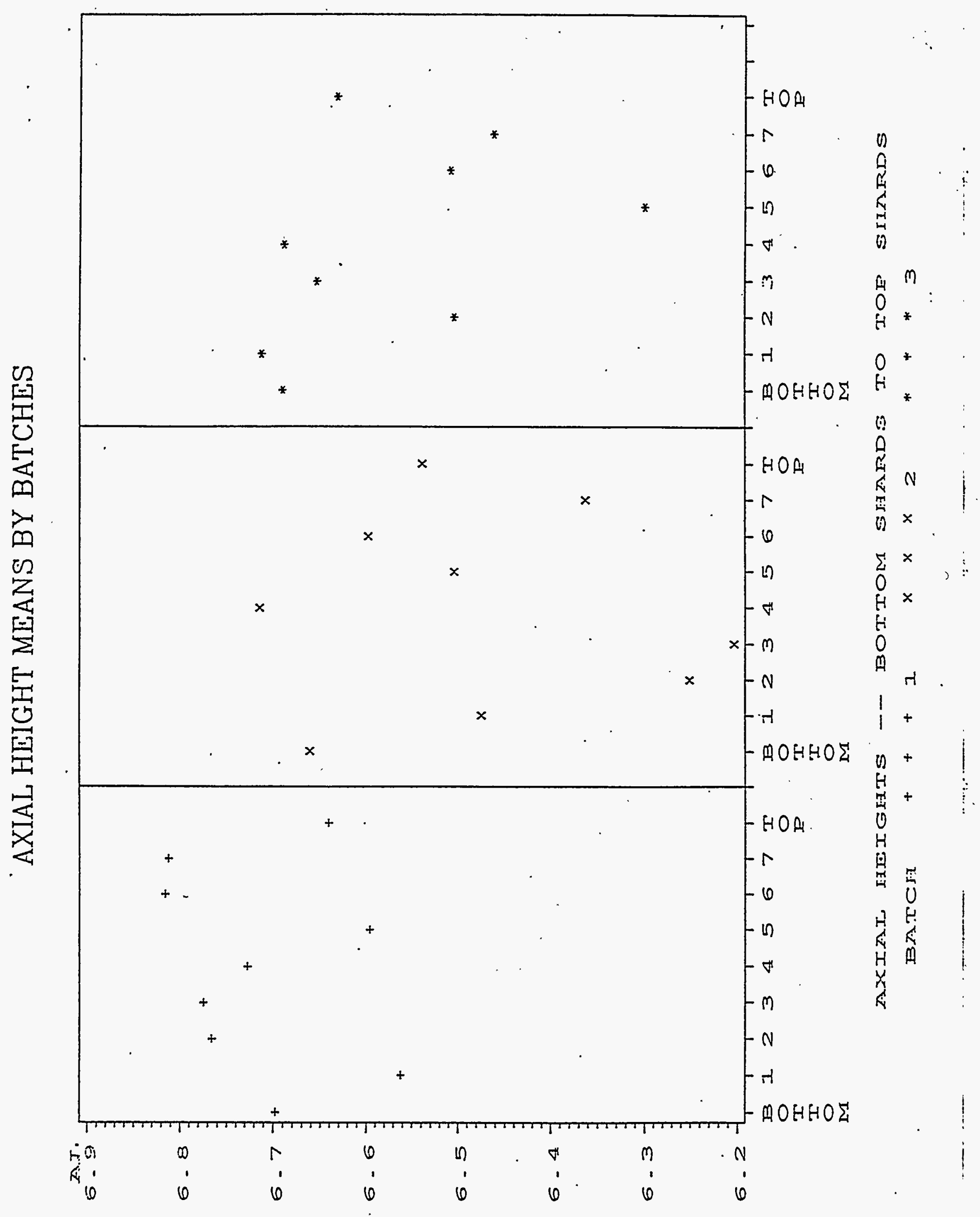




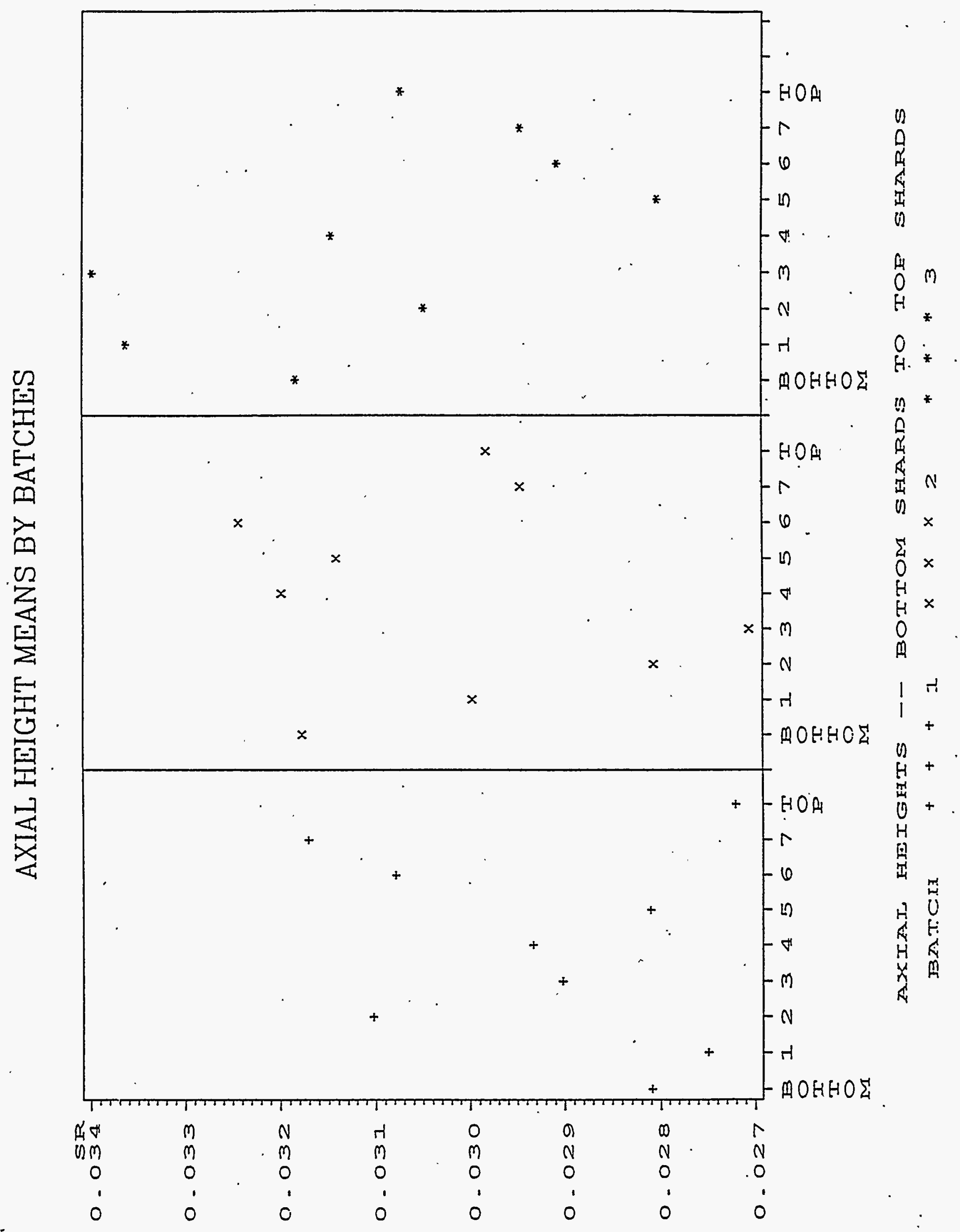




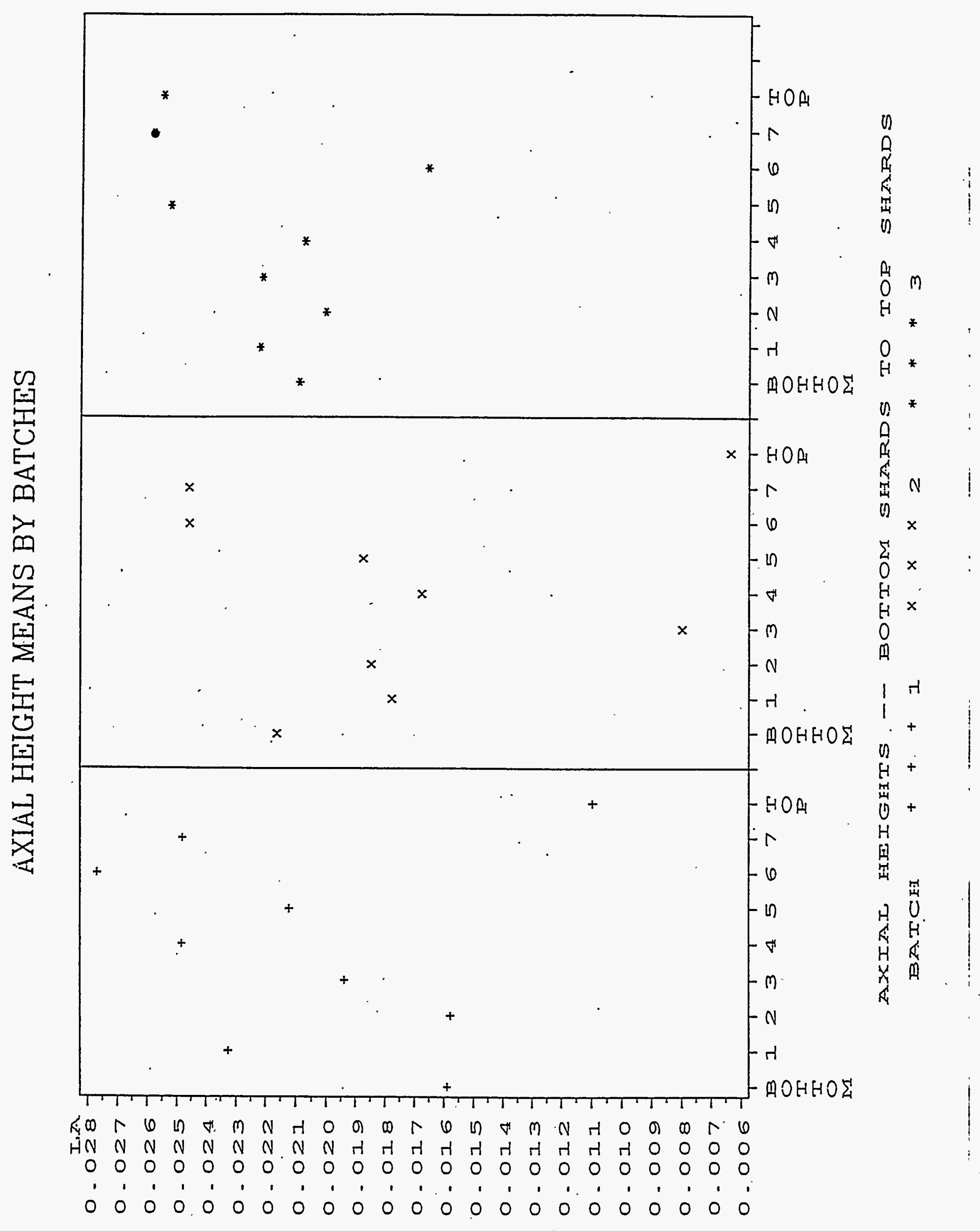




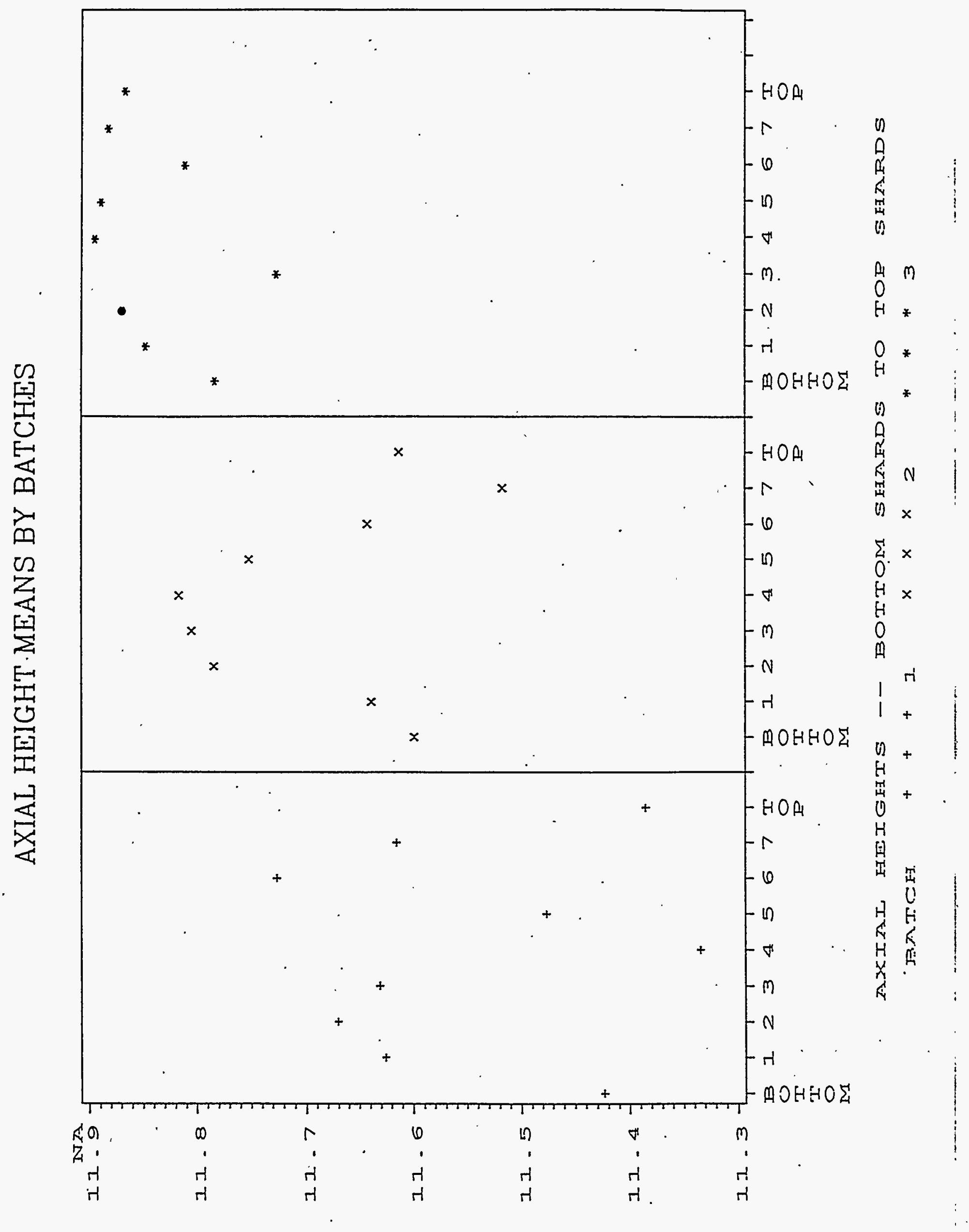


AXIAL HEIGHT MEANS BY BATCHES

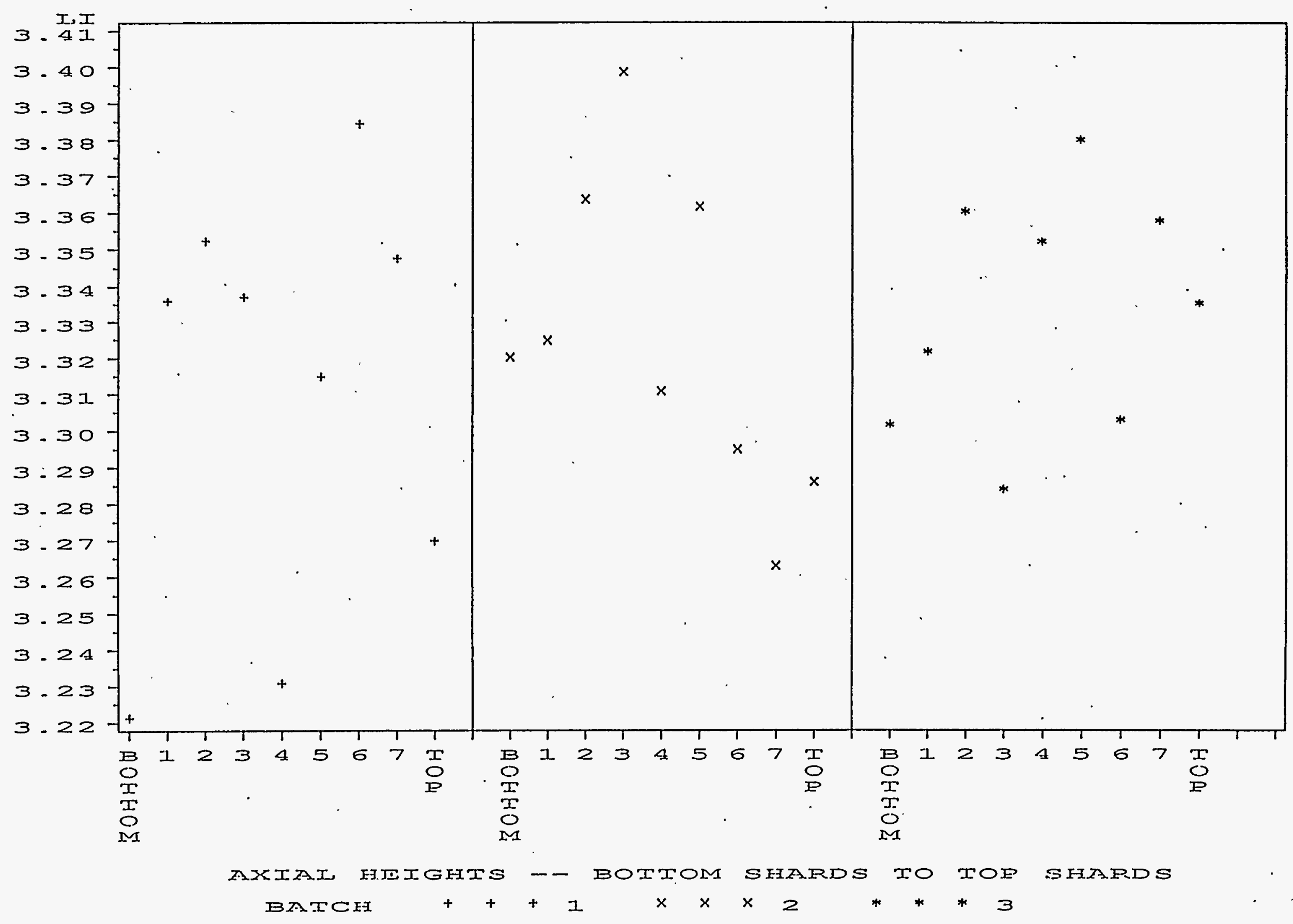




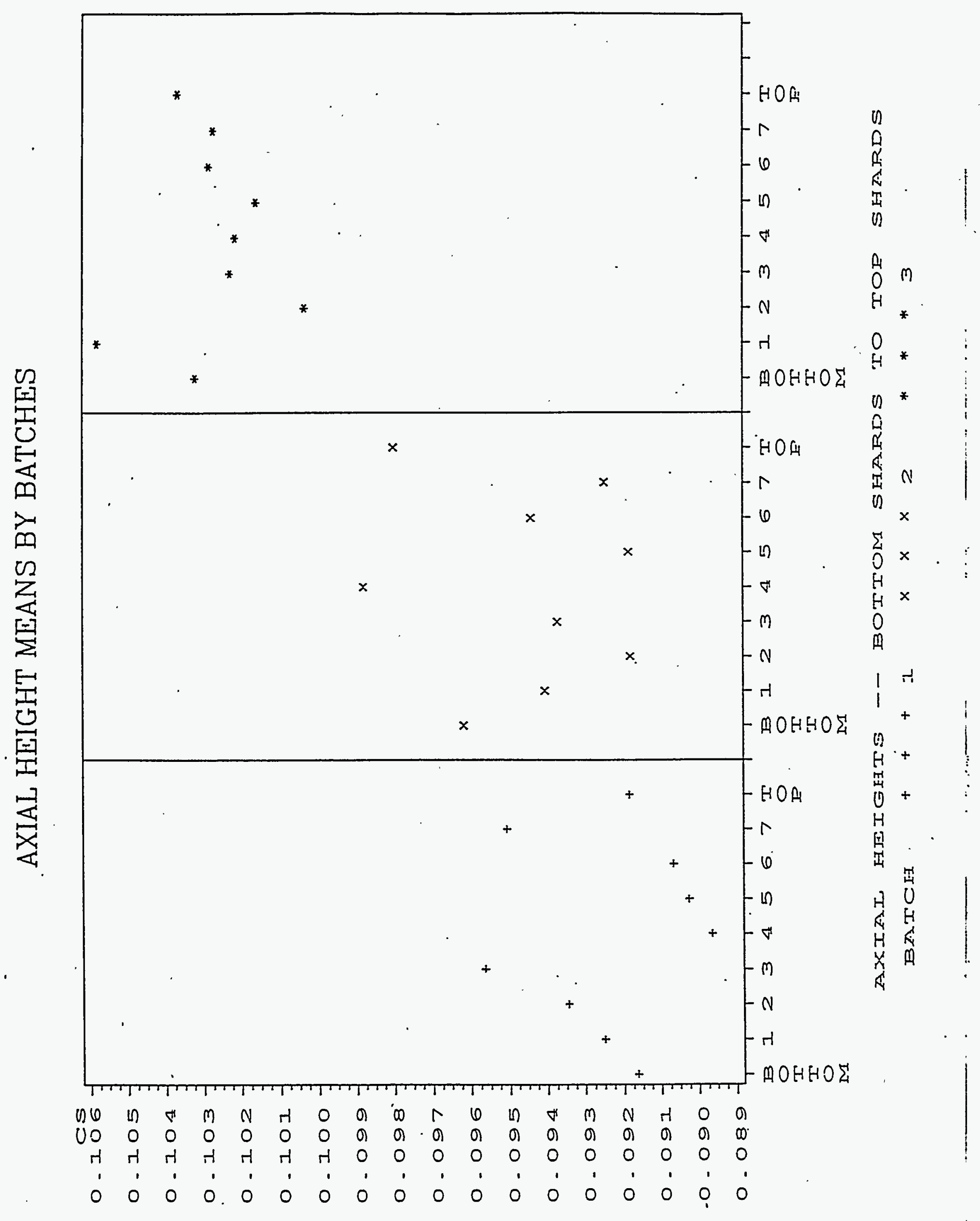




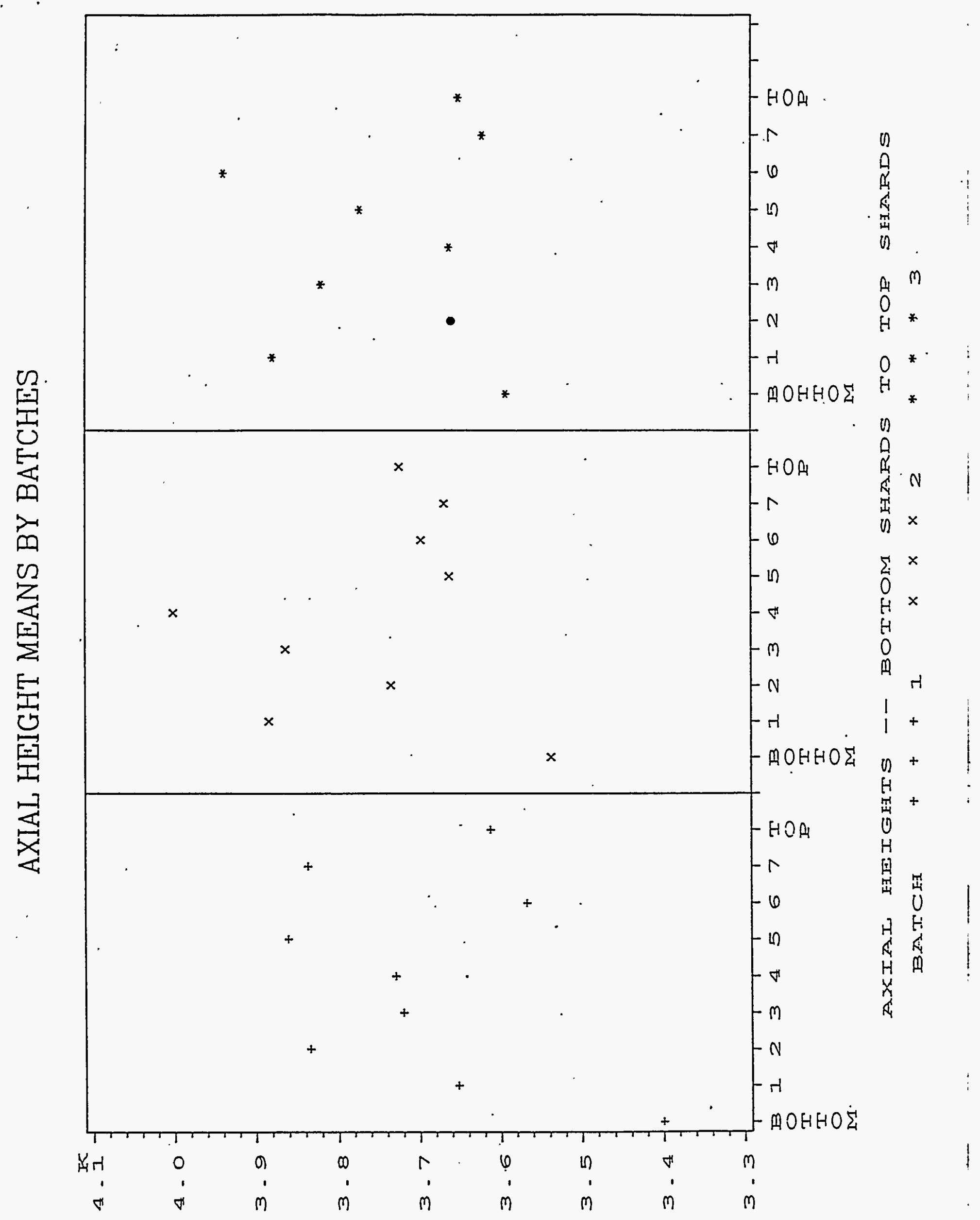


- APPENDIX B

LISTING OF DATA 


\begin{tabular}{|c|c|c|c|c|c|c|c|c|c|c|c|c|c|c|}
\hline & & $\begin{array}{l}\mathbf{S} \\
\mathbf{A}\end{array}$ & & $\mathbf{P}$ & $\mathbf{s}$ & B & $\begin{array}{l}M \\
0\end{array}$ & $\begin{array}{l}z \\
H\end{array}$ & $\begin{array}{l}n \\
I\end{array}$ & $\begin{array}{l}\mathbf{B} \\
\dot{A}\end{array}$ & $\stackrel{M}{N}$ & $\begin{array}{l}E \\
E\end{array}$ & $\begin{array}{l}\mathbf{C} \\
\mathbf{R}\end{array}$ & $\begin{array}{l}\mathbf{M} \\
\mathbf{G}\end{array}$ \\
\hline & & $M$ & & $=$ & $\overline{-}$ & $\overline{-}$ & - & - & - & - & - & - & - & - \\
\hline & $\begin{array}{l}\mathbf{L} \\
\mathbf{O}\end{array}$ & L & & $\overline{0}$ & $\overline{0}$ & $\overline{0}$ & $\overline{0}$ & $\overline{0}$ & $\overline{0}$ & $\overline{0}$ & $\overline{0}$ & $\overline{0}$ & $\overrightarrow{0}$ & $\overline{0}$ \\
\hline $\mathbf{0}$ & G & E & C & $\mathbf{x}$ & $x$ & $\mathrm{x}$ & $\mathrm{x}$ & $\mathrm{x}$ & $\mathbf{x}$ & $\mathrm{x}$ & $\mathrm{x}$ & $x$ & $\mathrm{x}$ & $\mathrm{x}$ \\
\hline B & & & A & $I$ & I & I & I & I & I & I & I & I & I & I \\
\hline $\mathbf{s}$ & $\because$ & $\overline{3}$ & N & D & D & D & D & D & D & D & D & D & D & D \\
\hline 1 & $9001610 A$ & WV-65A-5H1 & 65 & 2.53537 & 0.21440 & 10.2336 & 0.050386 & 0.34309 & 0.25209 & 0.09633 & 0.97151. & 11.7635 & 0.14368 & 0.86886 \\
\hline 2 & $9001617 \mathrm{~A}$ & WV $-65 A-S H 2$ & 65 & 2.50911 & 0.21621 & 10.2965 & 0.050798 & 0.23705 & 0.24584 & 0.15805 & 0.97463 & 11.7817 & 0.14887 & 0.90365 \\
\hline 3 & $9001623 \mathrm{~A}$ & WV-65A-SH3 & 65 & 2.55287 & 0.31718 & 10.2523 & 0.056091 & 0.31230 & 0.25562 & 0.09485 & 0.96948 & 11.6787 & 0.15271 & 0.89467 \\
\hline 4 & $9001699 A$ & $W V-66 A-17.5-4$ & 66 & 2.64731 & 0.00000 & 10.6917 & 0.044428 & 0.36180 & 0.23889 & 0.08893 & 0.99127 & 12.0397 & 0.08356 & 76143 \\
\hline 5 & $9001699 B$ & WV $-66 A-17.5-4$ & 66 & 2.62809 & 0.00206 & 10.6855 & 0.045828 & 0.36303 & 0.24145 & 0.08975 & 0.98788 & 12.0213 & 0.09176 & 76590 \\
\hline 6 & $9001677 \mathrm{~A}$ & $W V-66 A-17.5-8$ & 66 & 2.57695 & 0.11776 & 10.4052 & 0.047296 & 0.34990 & 0.22467 & 0.09283 & 0.96532 & 11.6542 & 0.06338 & 1857 \\
\hline & $9001677 \mathrm{~B}$ & $W V-66 A-17.5-8$ & 66 & 2.53561 & 0.10615 & 10.2660 & 0.046809 & 0.34464 & 0.22427 & 0.09036 & 0.95448 & 11.5138 & 0.06393 & 8617 \\
\hline 8 & $9001656 \mathrm{~A}$ & $\begin{array}{l}\text { WV }-66 A-17 \cdot 5-1 \\
\text { WV }-66 A-17 \cdot 5-1\end{array}$ & 66 & 2.57611 & 0.29088 & 10.8780 & 0.055412 & 0.36295 & 0.24314 & 0.09257 & 0.98920 & 11.9251 & 0.07776 & 0.55981 \\
\hline 9 & $\begin{array}{l}9001656 \mathrm{~B} \\
9001667 \mathrm{~A}\end{array}$ & $\begin{array}{l}W V-66 A-17 \cdot 5-1 \\
W V-66 A-33-4\end{array}$ & 66 & 2.59451 & 0.33148 & 10.7515 & 0.056486 & 0.36056 & 0.24803 & 0.10255 & 0.97715 & 11.7921 & 0.07524 & $0: 77238$ \\
\hline $\begin{array}{l}10 \\
11\end{array}$ & $\begin{array}{l}9001667 \mathrm{~A} \\
9001667 \mathrm{~B}\end{array}$ & $\begin{array}{l}W V-66 A-33-4 \\
W V-66 A-33-4\end{array}$ & $\begin{array}{l}66 \\
66\end{array}$ & $\begin{array}{l}2.57156 \\
2.54801\end{array}$ & $\begin{array}{l}0.16003 \\
0.18299\end{array}$ & $\begin{array}{l}10.6430 \\
10.5968\end{array}$ & $\begin{array}{l}0.049290 \\
0.049704\end{array}$ & $\begin{array}{l}0.37153 \\
0.36343\end{array}$ & $\begin{array}{l}0.22081 \\
0.23250\end{array}$ & $\begin{array}{l}0.08860 \\
0.09203\end{array}$ & $\begin{array}{l}0.98408 \\
0.97703\end{array}$ & $\begin{array}{l}11.8587 \\
11.7591\end{array}$ & $\begin{array}{l}0.10356 \\
0.10156\end{array}$ & $\begin{array}{l}0.70970 \\
0.80246\end{array}$ \\
\hline 12 & $9001712 \mathrm{~A}$ & $W V-66 A-33-8$ & 66 & 2.53422 & 0.18216 & 10.2278 & 0.053621 & 0.31932 & 0.23288 & 0.14012 & 0.95696 & 11.5722 & 0.11494 & 0.90533 \\
\hline 13 & $9001712 \mathrm{~B}$ & $W V-66 A-33-8$ & 66 & 2.53976 & 0.05085 & 10.4909 & 0.048958 & 0.31066 & 0.23010 & 0.13129 & 0.97304 & 11.8245 & 0.11232 & 0.90681 \\
\hline $\begin{array}{l}14 \\
15\end{array}$ & $\begin{array}{l}9001704 \mathrm{~A} \\
9001704 \mathrm{~B}\end{array}$ & $\begin{array}{l}W V-66 A-33-12 \\
W V-66 A-33-12\end{array}$ & $\begin{array}{l}66 \\
66\end{array}$ & $\begin{array}{l}2.59056 \\
2.60196\end{array}$ & $\begin{array}{l}0.00000 \\
0.00000\end{array}$ & $\begin{array}{l}10.6807 \\
10.6560\end{array}$ & $\begin{array}{l}0.051210 \\
0.051458\end{array}$ & $\begin{array}{l}0.35114 \\
0.35269\end{array}$ & $\begin{array}{l}0.22333 \\
0.22545\end{array}$ & $\begin{array}{l}0.10230 \\
0.10025\end{array}$ & $\begin{array}{l}0.99591 \\
0.99803\end{array}$ & $\begin{array}{l}12.0894 \\
12.1225\end{array}$ & $\begin{array}{l}0.08743 \\
0.08874\end{array}$ & 0.94871 \\
\hline 16 & $9001707 \mathrm{~A}$ & WV $-66 A-47.5-4$ & 66 & 2.64626 & 0.00000 & 10.5804 & 0.057464 & 0.37769 & 0.23603 & 0.09503 & 0.98955 & 12.0214 & 0.10378 & 0.93521 \\
\hline 17 & $9001707 \mathrm{~B}$ & $W V-66 A-47 \cdot 5-4$ & .66 & 2.62266 & 0.00000 & 10.5402 & 0.057478 & 0.37726 & 0.23661 & 0.09451 & 0.98950 & 12.0096 & 0.10387 & 0.95405 \\
\hline 18 & $\begin{array}{l}9001633 \mathrm{~A} \\
9001633 \mathrm{~B}\end{array}$ & $\begin{array}{l}W V-66 A-47 \cdot 5-8 \\
W V-66 A-47.5-8\end{array}$ & $\begin{array}{l}66 \\
66\end{array}$ & $\begin{array}{l}2.54709 \\
2.52358\end{array}$ & $\begin{array}{l}0.17073 \\
0.15020\end{array}$ & $\begin{array}{l}10.5777 \\
10.5802\end{array}$ & $\begin{array}{l}0.050376 \\
0.050512\end{array}$ & $\begin{array}{l}0.37305 \\
0.37305\end{array}$ & $\begin{array}{l}0.22530 \\
0.22619\end{array}$ & & & 11.8659 & & 0.93672 \\
\hline 19 & & $n V-00 \mathrm{~m}-1.0-0$ & & & . . 1 & & 0.050512 & נינד & 0.22 & 8282 & 0.98245 & 11.8923 & 0.09578 & 0.90900 \\
\hline
\end{tabular}

\begin{tabular}{|c|c|c|c|c|c|c|c|c|c|c|c|c|c|c|c|}
\hline - & $\begin{array}{l}S \\
I\end{array}$ & $\begin{array}{l}C \\
U\end{array}$ & $\begin{array}{l}T \\
I\end{array}$ & $\begin{array}{l}\mathbf{Z} \\
\mathrm{R}\end{array}$ & $\begin{array}{l}\mathbf{C} \\
\AA\end{array}$ & $\begin{array}{l}\text { A } \\
\text { L }\end{array}$ & $\begin{array}{l}S \\
R\end{array}$ & I & II & I & $\begin{array}{l}C \\
S\end{array}$ & $\mathrm{~K}$ & & & \\
\hline - & - & - & - & - & - & - & - & - & $\overline{0}$ & $\overline{0}$ & $\overline{0}$ & $\overline{0}$ & $\begin{array}{l}R \\
\text { A } S\end{array}$ & B & D $\stackrel{H}{E}$ \\
\hline & $\overline{0}$ & $\overline{\mathbf{o}}$. & $\overline{0}$ & $\overline{\mathrm{o}}$ & $\overline{0}$ & $\overline{0}$ & $\overline{0}$ & $\overline{0}$ & $x$ & $x$ & $x$ & $x$ & $\mathrm{D}$ & $\mathrm{A}$ & E I \\
\hline 0 & $x$ & $\mathrm{x}$ & $x$ & $\mathrm{x}$ & $\mathrm{x}$ & $\mathrm{x}$ & $x$ & $x$ & $I$ & $I$ & $\mathbf{I}$ & $I$ & I A & $\mathbf{T}$ & P $G$ \\
\hline B & I & $I$ & I & I & $I$ & $I$ & $I$ & $I$ & D & D & D & D & A $R$ & C & T \\
\hline s & D & D & D & D & D & D & D & D & E & $E$ & $\mathbf{E}$ & $\mathbf{E}$ & I $\quad D$ & II & H T \\
\hline
\end{tabular}

$\begin{array}{llllllllllllllll}1 & 44.1111 & 0.053867 & 0.80135 & 2.03774 & 0.45058 & 6.80899 & 0.028396 & 0.016151 & 11.4566 & 3.26349 & 0.08872 & 3.41029\end{array}$

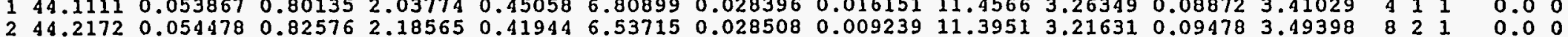

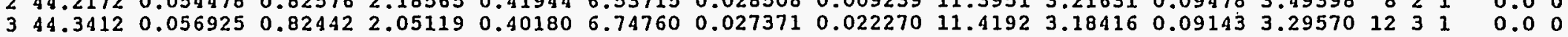

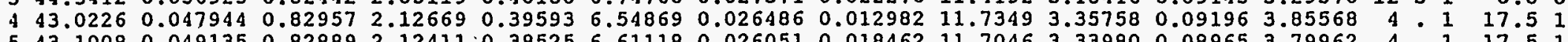

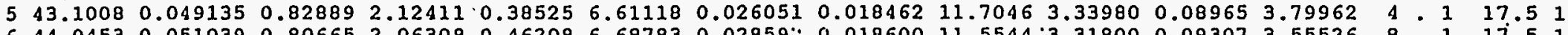

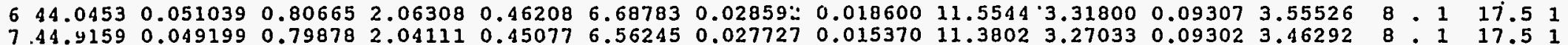

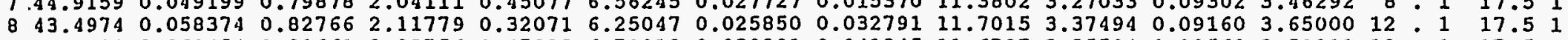

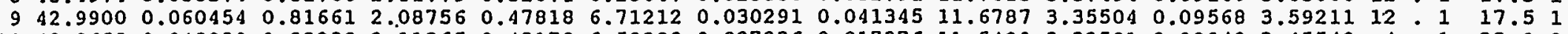

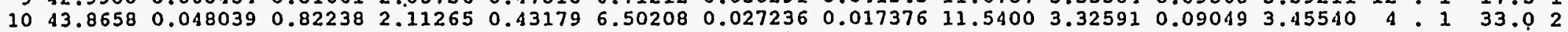

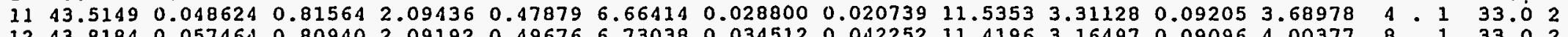

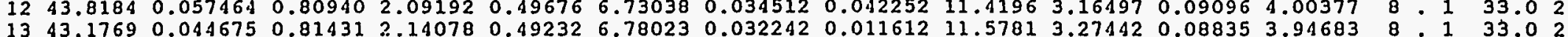
$\begin{array}{llllllllllllllllllll}14 & 41.7791 & 0.051361 & 0.84913 & 2.17376 & 0.50497 & 6.97260 & 0.031049 & 0.014960 & 11.9756 & 3.43033 & 0.10123 & 3.99519 & 12 & 0.1 & 33.0 & 2\end{array}$ $\begin{array}{lllllllllllllllllll}15 & 41.8851 & 0.051906 & 0.85001 & 2.17495 & 0.49219 & 6.94575 & 0.032330 & 0.014217 & 11.9731 & 3.41943 & 0.09762 & 3.91541 & 12 & 1 & 33.0 & 2\end{array}$

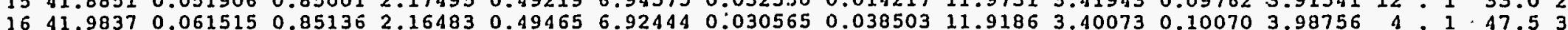
$1742.01740 .0605840 .849062 .162930 .512256 .949490 .0315340 .03937611 .97443 .384200 .097914 .03517 \quad 4 \cdot 1.47 .53$

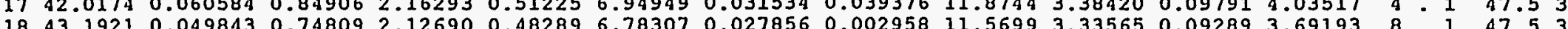

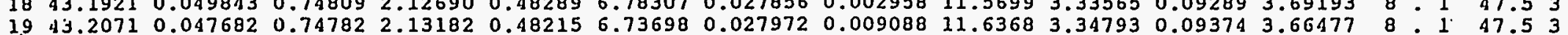


The sas system

\begin{tabular}{|c|c|c|}
\hline & & \multirow[t]{2}{*}{$\mathbf{s}$} \\
\hline & & \\
\hline & L & $\mathbf{P}$ \\
\hline & 0 & $\mathbf{L}$ \\
\hline 0 & G & $\mathbf{E}$ \\
\hline$B$ & - & \\
\hline $\mathbf{s}$ & - & $\overline{\mathbf{N}}$ \\
\hline & $9001679 A$ & WV $-66 A-47.5-1$ \\
\hline 21 & $9001679 \mathrm{~B}$ & WV $-66 A-47.5-1$ \\
\hline 22 & 9001710A & WV $-66 A-.60-4$ \\
\hline 23 & $9001710 \mathrm{~B}$ & FV $-66 A-60-4$ \\
\hline 24 & $9001697 \mathrm{~A}$ & $W V-66 A-60-8$ \\
\hline 25 & $9001697 \mathrm{~B}$ & WV $-66 A-60-8$ \\
\hline 26 & $9001634 \mathrm{~A}$ & WV $-66 A-60-12$ \\
\hline 27 & $9001634 \mathrm{~B}$ & WV $-66 A-60-12$ \\
\hline 28 & $9001738 \mathrm{~A}$ & $W V-66 A-75-4$ \\
\hline 29 & $9001738 \mathrm{~B}$ & WV $-66 A-75-4$ \\
\hline 30 & $9001739 \mathrm{~A}$ & WV $-66 A-75-8$ \\
\hline 31 & $9001739 \mathrm{~B}$ & $W V-66 A-75-8$ \\
\hline 32 & $9001669 A$ & WV $-66 A-75-12$ \\
\hline 33 & $9001669 \mathrm{~B}$ & $W V-66 A-75-12$ \\
\hline 34 & $9001666 \mathrm{~A}$ & $W V-66 A-85 \cdot 5-4$ \\
\hline 35 & $9001666 \mathrm{~B}$ & $W V-66 A-85.5-4$ \\
\hline 36 & $9001684 \mathrm{~A}$ & $W V-66 A-85.5-8$ \\
\hline 37 & $900168 \ddot{4 B}$ & $W V-66 A-85.5-8$ \\
\hline 38 & $9001631 \AA$ & $W V-66 A-85.5-1$ \\
\hline
\end{tabular}

C

6
6
6
6
6
6
6
6
6
6
6
6
6
6
6
6
6
6
6

2.52998

0.13072

$2.48850-0.17830$

2.45839

$\begin{array}{ll}2.55593 & 0.15668 \\ 2.49067 & 0.15198\end{array}$

2.48530

2.52164

$2.59645 \quad 0.03696$

$2.62202 \quad 0.02576$

$\begin{array}{ll}2.55191 & 0.05294 \\ 2.53909 & 0.13286\end{array}$

$2.52902 \quad 0.16941$

$\begin{array}{ll}2.57558 & 0.16695 \\ 2.55548 & 0.15864\end{array}$

2.615590 .05924

$\begin{array}{ll}2.62441 & 0.00000 \\ 2.55963 & 0.32651\end{array}$
12:23 Eriday, December 21, 1990

$2.50103 \quad 0.12934$

$B$
$\overline{-}$
$\bar{D}$
$\mathrm{X}$
$\mathrm{I}$
$\mathrm{D}$

10.3458 10.3698
10.2420

10.2420
10.2094

10.3345

10.4079
10.3931

10.3939

10.4775

10.6551

10.5811

10.4630

10.4773

10.6520

10.8518
10.8280

10.8280
10.7612
IS
$\mathrm{O}$
-
$\bar{O}$
$\mathrm{X}$
$\mathrm{I}$

0.050571 0.050648 0.052100
0.050409

0.050409

0.048566
0.048723

0.051130

0.051751

0.050513
0.050406

0.049454

0.050439

$0: 051754$

0.053950

0.049119

0.049835

.047447

0.057018
$12: 23$ Er

Z
N
-
$\bar{O}$
$\mathrm{X}$
$\mathrm{I}$
$\mathrm{D}$

$\begin{array}{ccc}\text { C } & \text { A } & \text { S } \\ \text { A } & \text { L } & \text { R } \\ - & - & - \\ \bar{D} & \bar{O} & \bar{O} \\ \text { X } & \text { X } & \text { X } \\ \text { I } & \text { I } & \text { I } \\ \text { D } & \text { D } & \text { D }\end{array}$

$M$

$\mathrm{N}$

$\overline{\mathrm{o}}$

$\mathrm{X}$

$0.36242 \quad 0.21703 \quad 0.08681$

0.36383

0.36127
0.36319

0.36319

0.36749
0.35717

0.35717
0.35950

0.37713

0.37795

0.37589

0.37220
0.36912

0.36912
0.38075

0.37935

0.38755

0.38656

0.38656

\begin{tabular}{|c|c|c|}
\hline I & I & $I$ \\
\hline $\boldsymbol{A}$ & $A$ & $I$ \\
\hline- & $\overline{0}$ & $\overline{\mathrm{O}}$ \\
\hline$\overline{0}$ & $\mathrm{x}$ & $\mathrm{x}$ \\
\hline $\mathrm{x}$ & $I$ & I \\
\hline$I$ & $D$ & D \\
\hline D & $E$ & $E$ \\
\hline
\end{tabular}

0.09358

0.23210

0.22627

0.07409

$0.23301 \quad 0.08130$
F
E
D
X
I
D

C

11

$\overline{0}$ $\begin{array}{llll}0.22710 & 0.08400 & 0.96735 & 11.6537\end{array}$

0.223370 .0889

0.94935

$0.95493 \quad 11.5507$

11.5507
11.5499 0.08223

0.08007

0.07591

0.07397

$\begin{array}{lll}0.96232 & 11.5110 & 0.10025 \\ 0.96201 & 11.6138 & 0.09334\end{array}$

$\begin{array}{lll}0.96201 & 11.6138 & 0.09334 \\ 0.96651 & 11.6930 & 0.12610\end{array}$

$\begin{array}{lll}0.96676 & 11.7217 & 0.12336\end{array}$

$\begin{array}{lll}0.97403 & 11.7880 & 0.07008 \\ 0.96744 & 11.6878 & 0.07558\end{array}$

0.96744

0.96777

0.96777
0.96490

11.6762

0.07558

0.08765

0.08869

$\begin{array}{lll}.22635 & 0.08695 & 0.97602\end{array}$

11.7658

$0.97443 \quad 11.7576 \quad 0.06539$

$\begin{array}{llllll}0.18997 & 0.09223 & 0.99065 & 11.9480 & 0.05830 & 0.94398\end{array}$

0.83543
0.05830

$\begin{array}{llllll}0.19428 & 0.08650 & 0.99545 & 12.0038 & 0.05620 & 0.93435\end{array}$

$0.97285 \quad 11.7829 \quad 0.12312 \quad 0.92694$

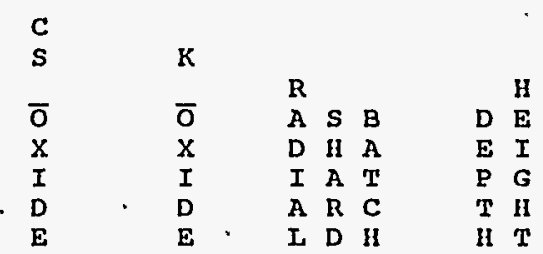

$\begin{array}{llllllllllllllllll}20 & 44.3823 & 0.046678 & 0.79853 & 2.06678 & 0.48062 & 6.70517 & 0.028653 & 0.0134 .13 & 11.3774 & 3.26728 & 0.09315 & 3.49208 & 12 & 0.4 & 47.5 & 3\end{array}$

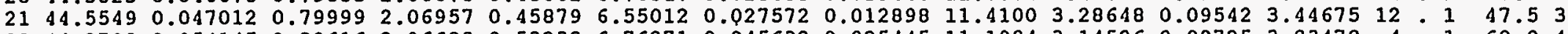
$\begin{array}{llllllllllllllllll}22 & 44.3798 & 0.054145 & 0.80616 & 2.06688 & 0.53233 & 6.76271 & 0.045632 & 0.025445 & 11.1984 & 3.14526 & 0.08725 & 3.83478 & 4 & 0.1 & 60.0 & 4\end{array}$

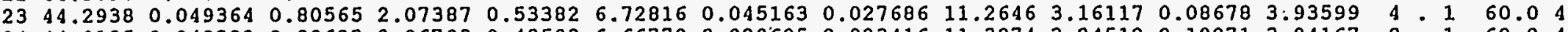

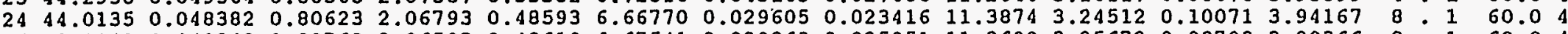
$\begin{array}{lllllllllllllllllll}25 & 43.9941 & 0.049342 & 0.80769 & 2.06503 & 0.48619 & 6.67541 & 0.029868 & 0.025951 & 11.3699 & 3.25672 & 0.08703 & 3.80366 & 8 & 0.1 & 60.0 & 4\end{array}$ $\begin{array}{llllllllllllllll}26 & 44.3243 & 0.048119 & 0.78817 & 2.03055 & 0.49358 & 6.84283 & 0.030625 & 0.028326 & 11.3009 & 3.27728 & 0.08602 & 3.48926 & 12 & 1 & 60.04\end{array}$

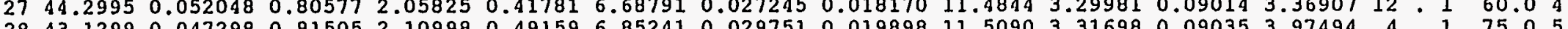

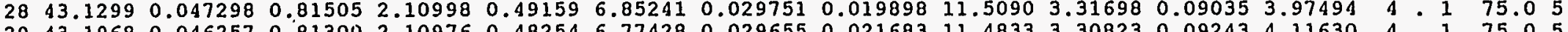
2943.19680 .0462570 .813002 .109760 .402546 .774280 .029650 .02168311 .48333 .30823 .0 .092434 .116304 .1275 .05

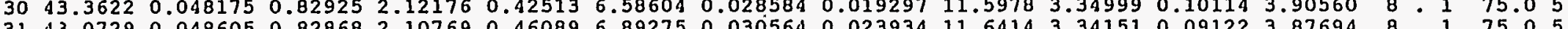
$\begin{array}{lllllllllllllll}31 & 43.0729 & 0.048605 & 0.82868 & 2.10769 & 0.46089 & 6.89275 & 0.030564 & 0.023934 & 11.6414 & 3.34151 & 0.09122 & 3.87694 & 8 & 1 \\ 3 & 75.0 & 5\end{array}$

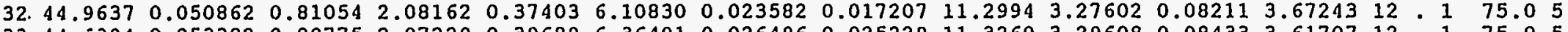
$\begin{array}{llllllllllllllllll}33 & 4.4 .6394 & 0.053382 & 0.80775 & 2.07229 & 0.39689 & 6.36401 & 0.026496 & 0.025229 & 11.3260 & 3.29608 & 0.08433 & 3.61707 & 12 & 0 & 1 & 75.0 & 5\end{array}$ $\begin{array}{lllllllllllllllll}34 & 41.5153 & 0.050878 & 0.82257 & 2.12313 & 0.47813 & 6.65750 & 0.029505 & 0.023474 & 11.5759 & 3.34183 & 0.09116 & 3.50848 & 4 & 0.1 & 85.5 & 6\end{array}$

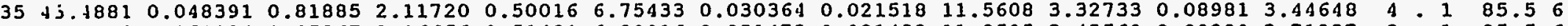

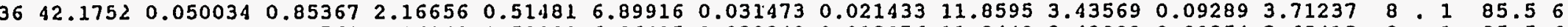

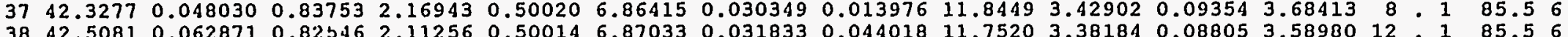


The sas system

\begin{tabular}{|c|c|c|}
\hline & & $\begin{array}{l}\mathbf{S} \\
\mathrm{A} \\
\mathrm{M}\end{array}$ \\
\hline & L & $\mathrm{P}$ \\
\hline & 0 & L \\
\hline 0 & G & E \\
\hline B & & \\
\hline$s$ & - & $\overline{\mathbf{N}}$ \\
\hline 39 & $9001631 \mathrm{~B}$ & $W V-66 A-85.5-1$ \\
\hline 40 & $9001708 \mathrm{~A}$ & WV $-66 A-103-4$ \\
\hline 41 & $9001708 B$ & WV $-66 A-103-4$ \\
\hline 42 & $9001695 \dot{A}$ & $W V-66 A-103-8$ \\
\hline 43 & $9001695 B$ & $W V-66 A-103-8$ \\
\hline 44 & $9001700 \mathrm{~A}$ & $W V-66 A-103-1$ \\
\hline 45 & $9001700 \mathrm{~B}$ & $6 V-65 A-103-1$ \\
\hline 46 & $9001613 \mathrm{~A}$ & WV-66A-SH1 \\
\hline 47 & $9001006 \mathrm{~A}$ & WV $-66 A-S H 2$ \\
\hline 48 & $.9001014 \mathrm{~A}$ & WV $-66 A-5112$ \\
\hline 49 & $9001008 \mathrm{~A}$ & $F V-66 A-S 113$ \\
\hline 50 & $9001612 A$ & WV-41A-SH1 \\
\hline 51 & $9001625 A$ & WV- $41 A-S H 3$ \\
\hline 52 & $9001706 \mathrm{~A}$ & WV $-44 A-7-4$ \\
\hline & $9001706 \mathrm{~B}$ & $W V-44 A-7-4$ \\
\hline 54 & $9001668 \mathrm{~A}$ & $W V-44 A-7-8$ \\
\hline 55 & $9001668 \mathrm{~B}$ & $W V-44 A-7-8$ \\
\hline 56 & 9001730A & $W V-44 A-7-12$ \\
\hline & $9001730 \mathrm{~B}$ & $W V-44 A-7-12$ \\
\hline
\end{tabular}

$\mathrm{C}$
$\mathrm{A}$
$\mathrm{N}$

$\mathbf{p}$

$\begin{array}{ll}66 & 2.58658\end{array}$

$\begin{array}{ll}66 & 2.52658 \\ 66 & 2.52868\end{array}$

$\begin{array}{ll}66 & 2.52868 \\ 66 & 2.59635\end{array}$

$\begin{array}{ll}66 & 2.63691\end{array}$

$\begin{array}{ll}66 & 2.61007\end{array}$

$\begin{array}{ll}66 & 2.59448 \\ 66 & 2.50879\end{array}$

$6 \quad 2.55514$

$66 \quad 2.44354$

$\begin{array}{ll}66 & 2.49081\end{array}$

$41 \quad 2.56357$

$41 \quad 2.57797$

44.58533

2.64844

2.49619
2.53247

$44 \quad 2.59602$

$\begin{array}{ll}44 & 2.59602 \\ 44 & 2.54322\end{array}$
S . B

$\begin{array}{ll}5 & -\end{array}$

$\overline{0}$

$\mathrm{x}$

I

D

0.36406

0.14806
0.15487

0.09349

0.05946

0.01795

0.24330

0.21059

0.22359

0.22883

0.23690

0.00000

0.09925

0.16178

0.12073

10.3229

\begin{tabular}{|c|c|c|c|c|c|c|c|c|c|c|c|c|c|c|}
\hline $\mathbf{s}$ & C & $\mathbf{T}$ & Z & C & A & $\mathbf{S}$ & L & $\mathrm{N}$ & L & C & & & & \\
\hline$I$ & $\mathbf{u}$ & $\bar{I}$ & $\mathbf{R}$ & A & L & $\mathrm{R}$ & A & A & I & $s$ & $\mathbf{K}$ & & & \\
\hline- & - & - & - & - & - & - & - & $\overline{0}$ & $\overline{0}$ & $\overline{0}$ & $\overline{0}$ & A $s$ & & D \\
\hline$\overline{0}$ & $\overline{0}$ & $\overline{0}$ & $\overline{0}$ & $\bar{\delta}$ & $\overline{0}$ & $\overline{0}$ & $\overline{0}$ & $\mathrm{x}$ & $\mathrm{x}$ & $x$ & $x$ & D II & A & $\mathrm{EI}$ \\
\hline$x$ & $x$ & $x$ & $x$ & $x$ & $x$ & $x$ & $x$ & $\mathrm{I}$ & $I$ & I & I & I A & $\mathbf{T}$ & $\mathbf{P}$ \\
\hline$I$ & I & I & I & I & $I$ & I & $\mathbf{I}$ & D & D & D & D & $A R$ & C & $T$ \\
\hline D & D & D & D & D & D & D & D & E & $E$ & $E$ & $\mathrm{E}$ & L D & $\Omega$ & H \\
\hline
\end{tabular}

\begin{tabular}{|c|c|c|c|c|c|c|c|c|c|c|c|c|c|c|}
\hline $\mathbf{s}$ & C & $\mathbf{T}$ & Z & C & A & $\mathbf{S}$ & L & $\mathrm{N}$ & L & C & & & & \\
\hline$I$ & $\mathbf{u}$ & $\bar{I}$ & $\mathbf{R}$ & A & L & $\mathrm{R}$ & A & A & I & $s$ & $\mathbf{K}$ & & & \\
\hline- & - & - & - & - & - & - & - & $\overline{0}$ & $\overline{0}$ & $\overline{0}$ & $\overline{0}$ & A $s$ & & D \\
\hline$\overline{0}$ & $\overline{0}$ & $\overline{0}$ & $\overline{0}$ & $\bar{\delta}$ & $\overline{0}$ & $\overline{0}$ & $\overline{0}$ & $\mathrm{x}$ & $\mathrm{x}$ & $x$ & $x$ & D II & A & $\mathrm{EI}$ \\
\hline$x$ & $x$ & $x$ & $x$ & $x$ & $x$ & $x$ & $x$ & $\mathrm{I}$ & $I$ & I & I & I A & $\mathbf{T}$ & $\mathbf{P}$ \\
\hline$I$ & I & I & I & I & $I$ & I & $\mathbf{I}$ & D & D & D & D & $A R$ & C & $T$ \\
\hline D & D & D & D & D & D & D & D & E & $E$ & $E$ & $\mathrm{E}$ & L D & $\Omega$ & H \\
\hline
\end{tabular}

12:23 Friday, December 21, 1990

5

$\begin{array}{llllllllllllllllllll}39 & 42.5700 & 0.066058 & 0.82798 & 2.11626 & 0.48907 & 6.85029 & 0.031201 & 0.041743 & 11.7637 & 3.39052 & 0.08856 & 3.46074 & 12 & 0.05 & 1 & 85.5 & 6\end{array}$

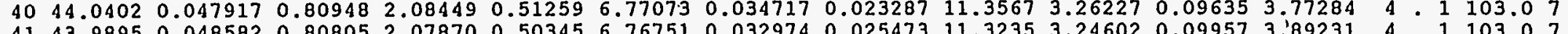

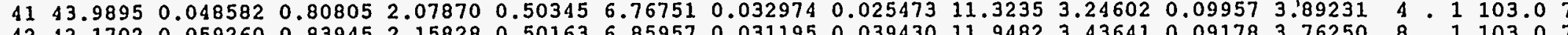

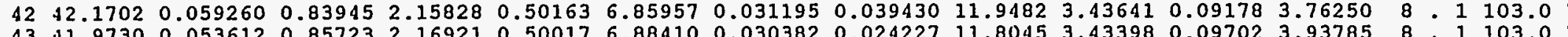
$\begin{array}{llllllllllllllll}43 & 41.9730 & 0.053612 & 0.85723 & 2.16921 & 0.50017 & 6.88410 & 0.030382 & 0.024227 & 11.8045 & 3.43398 & 0.09702 & 3.93785 & 8 & 0.03 & 103.0\end{array}$

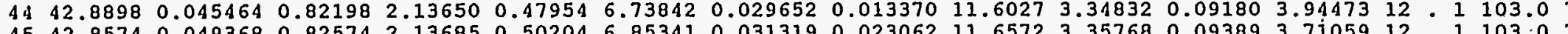

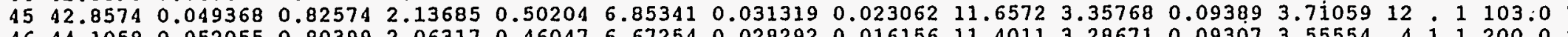
$\begin{array}{llllllllllllll}46 & 44.1058 & 0.052055 & 0.80399 & 2.06317 & 0.46047 & 6.67254 & 0.028292 & 0.016156 & 11.4011 & 3.28671 & 0.09307 & 3.55554\end{array}$

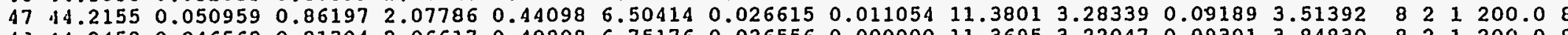

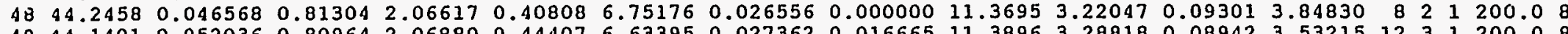

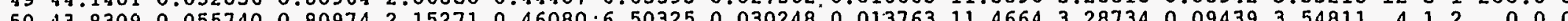

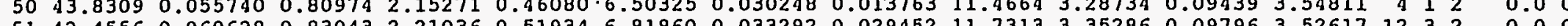

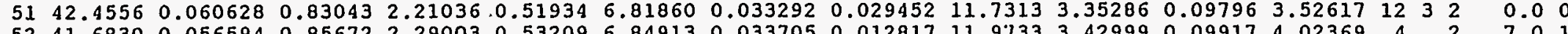

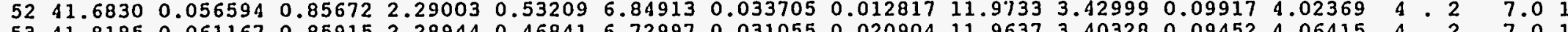

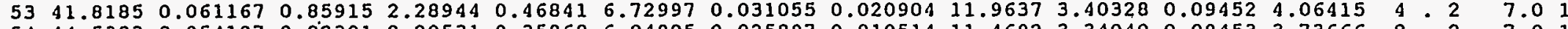
$\begin{array}{lllllllllllllll}54 & 44.5383 & 0.054107 & 0.82301 & 2.20531 & 0.35868 & 6.04905 & 0.025897 & 0.010514 & 11.4692 & 3.34040 & 0.09453 & 3.73666 & 8 & 0\end{array}$

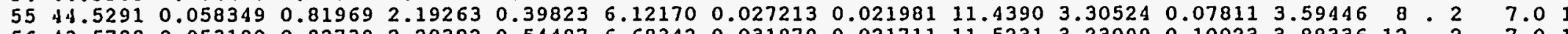

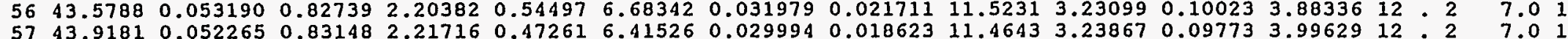


The SAS system

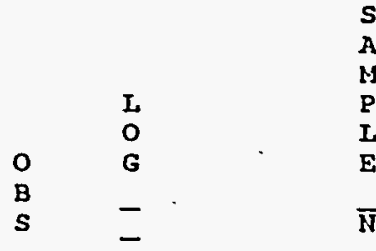

S
-
$\bar{O}$
$\mathrm{X}$
$\mathrm{I}$

$589001658 A$ WV-44A-23-4 $599001658 B$ WV $-44 A-23-4$ $609001652 \mathrm{~A}$ WV-44A-23-8

$619001652 \mathrm{~B}$ WV $-44 A-23-8$

$629001698 \mathrm{~A}$ WV-44A-23-12

$639001698 \mathrm{BV}-44 \mathrm{~A}-23-12$

$649001685 \mathrm{~A}$ WV-44A-37-4

$659001685 \mathrm{~B}$ WV-44A-37-4

65 001685B WV-44A-37-4

$679001696 \mathrm{~B} \quad \mathrm{WV}-44 \mathrm{~A}-37-8$

$689001737 A \quad W V-44 A-37-12$

$699001737 \mathrm{~B}$ WV $-44 \mathrm{~A}-37-12$

70 9001736A WV-44A-47-4

$719001736 \mathrm{~B}$ WV-44A-47-4

$729001732 A$ WV $-44 A-47-8$

$739001732 B$ WV $-44 A-47-8$

$749001705 A$ WV-44A-47-12

$759001705 \mathrm{~B}$ WV $-44 \mathrm{~A}-47-12$

$769001673 \mathrm{~A} \cdot \mathrm{WV}-44 \mathrm{~A}-61-4$

S
-
$\bar{O}$
$\mathrm{X}$
$\mathrm{I}$

2.61298

2.64311

2.58107

2.68550

2.64974

2.61835

2.62553

2.70495

2.69641
2.54436

2.62331

2.60698

2.62166

2.56041

2.56041
2.64068

2.62521

$44 \quad 2.64706$
12:23 Friday, December 21, 1990

$$
\begin{aligned}
& \text { Z } \\
& \text { II } \\
& - \\
& \bar{O} \\
& \text { X } \\
& \text { I } \\
& \text { D }
\end{aligned}
$$$$
\text { I }
$$

B
A
$\bar{D}$
$\bar{O}$
$\mathrm{X}$
$\mathrm{I}$
$\mathrm{D}$

$$
\begin{aligned}
& u \\
& \text { u } \\
& \bar{D} \\
& \mathrm{X}
\end{aligned}
$$

0.25358

11.03240 .052029
0.0319

0.00000

11.0319

$10.8761 \quad 0.042094$

10.8949

0.042740

0.046055

0.00000

0.043599

$\begin{array}{ll}0.04633 & 10.9633 \\ 0.03751 & 10.9352\end{array}$

$\begin{array}{lll}0.18539 & 10.1954 & 0.052959\end{array}$

0.2698410 .3253

$\begin{array}{ll}0.14491 & 10.5905 \\ 0.19279 & 10.5739\end{array}$

0.19279

$0.05114 \quad 10.5569$

0.059002

0.050543

0.054032

0.046986

0.048694

$0.00000 \quad 10.7055$

0.046992

$\begin{array}{llll}0.23467 & 0.22496 & 0.19898\end{array}$ $\begin{array}{lll}0.23056 & 0.20537 & 0.20352 \\ 0.24002 & 0.25678 & 0.18376\end{array}$ 0.24002

$\begin{array}{ll}0.23829 & 0.23700\end{array}$

.271610 .241850 .15116

$\begin{array}{lll}0.26882 & 0.23589 & 0.16045\end{array}$

0.22042 .0 .17387

0.20849

0.19448

0.23662

0.222790 .237910 .18555

$\begin{array}{lll}0.21066 & 0.22819 & 0.21041\end{array}$

0.215300 .23927

$0.20854 \quad 0.21995$

0.208440 .22070

0.19967

0.21219

0.22467

0.20593

0.21773

0.22355

$\begin{array}{ll}0.20809 & 0.20293 \\ 0.21041 & 0.20970\end{array}$

0.21462

0.21041
0.20065

0.21871

0.21174

$\begin{array}{lll}1.21490 & 0.97819\end{array}$

$\begin{array}{ll}\text { L } & \text { N } \\ \text { A } & \text { A } \\ - & \\ \bar{O} & \\ \text { X } & \text { X } \\ \text { I } & \text { I } \\ \text { D } & \text { E }\end{array}$

L
I
$\bar{O}$
X
I
D
E

$C$
$\mathbf{S}$
$\bar{O}$
$\mathrm{X}$
$\mathrm{I}$
$\mathrm{D}$
$\mathrm{E}$

$$
\begin{aligned}
& K \\
& \bar{O} \\
& X \\
& I \\
& D \\
& E
\end{aligned}
$$

K

$\bar{O}$
$\mathrm{X}$
$\mathrm{I}$
$\mathrm{D}$
$\mathrm{E}$

$\begin{array}{lll}\text { R } & & \\ \text { A } & \text { S } & \text { B } \\ \text { D } & \text { H } & \text { A } \\ \text { I } & \text { A } & \text { T } \\ \text { A } & \text { R } & \text { C } \\ \text { L } & \text { D } & \text { II }\end{array}$

E

P G

II $\quad$ T

$5842.91540 .062652 \quad 0.82490$

$\begin{array}{llll}58 & 42.9154 & 0.062652 & 0.82490 \\ 59 & 43.1511 & 0.058384 & 0.83580\end{array}$

2.23418

0.47536
0.49730

$6.46788 \cdot 0.03122$

$0.029938 \cdot 11.7608$

$0.022260 \quad 11.6636$

3.35773

$0.09151 \quad 3.55149$

$\begin{array}{lll}.32927 & 0.09297 \quad 3.47979\end{array}$

$3.39373 \quad 0.08707 \quad 3.76928$

3.391810 .08848

3.34596

$\begin{array}{llllll}0.30711 & 5.94697 & 0.027089 & 0.021108 & 11.6991\end{array}$

$\begin{array}{llllll}0.33866 & 6.06990 & 0.023777 & 0.006612 & 11.9142 \\ 0.39013 & 6.46480 & 0.027703 & 0.011822 & 11.9567\end{array}$

$\begin{array}{lllll}0.47864 & 6.57616 & 0.031490 & 0.011417 & 11.8627\end{array}$

$\begin{array}{llll}0.44914 & 6.34690 & 0.029593 & 0.000000\end{array}$

$5.86630-0.022711$

0.00000011 .8505

3.36338

3.43903

0.09900

0.09184

0.09509

$\begin{array}{llllll}65 & 42.1250 & 0.053401 & 0.84556 & 2.29996 \\ 65 & 42.2597 & 0.047569 & 0.84454 & 2.30640\end{array}$

$\begin{array}{llllll}66 & 43.2560 & 0.053297 & 0.85560 & 2.30807\end{array}$

$\begin{array}{lllll}6 \% & 43.0809 & 0.054805 & 0.85269 & 2.29568\end{array}$

$\begin{array}{lllll}68 & 43.0437 & 0.058649 & 0.83542\end{array}$

0.28703

6.025380 .024454

0.007620

11.7582

3.43903

0.09509

3.73440

$3.97898 \cdot 12$

3. 82420

3.82420

$6943.68320 .068066 \quad 0.852842 .16634$

$\begin{array}{lll}.49265 & 7.70057 & 0.034189\end{array}$

$0.032476 \quad 11.7480$

$\begin{array}{lll}16 & 0.09092 & 3.82998\end{array}$

$\begin{array}{llllll}7.25565 & 0.028701 & 0.047362 & 11.375 & 3.15775 & 0.08927\end{array}$

3.92232

$\begin{array}{lllllll}70 & 43.0669 & 0.054140 & 0.82520 & 2.24166 & 0.44822\end{array}$

6.425390 .0300310 .047362

11.6381

3.100140 .08948

$.28590 \quad 0.09559 \quad 4.07951$

$\begin{array}{llllllll}0.48498 & 6.76160 & 0.032063 & 0.030318 & 11.7556 & 3.26579 & 0.09323 & 3.90442\end{array}$

$\begin{array}{llllllll}0.54528 & 6.79153 & 0.057556 & 0.026138 & 11.7505 & 3.23047 & 0.09623 & 3.92112 \\ 0.53859 & 6.78354 & 0.055722 & 0.020735 & 11.7687 & 3.23847 & 0.10103 & 3.93642\end{array}$

$\begin{array}{llllllll}0.53859 & 6.78354 & 0.055722 & 0.020735 & 11.7687 & 3.23847 & 0.10103 & 3.93642 \\ 0.53221 & 6.82762 & 0.033746 & 0.006632 & 12.0135 & 3.42861 & 0.09936 & 4.05999\end{array}$

$\begin{array}{llll}73 & 0.0196 & 0.056336 & 0.826\end{array}$

734.7870 .0534600 .821652 .23209

$\begin{array}{lllll}75 & 41.6255 & 0.052328 & 0.85638 & 2.31912\end{array}$

$\begin{array}{lllll}0.53221 & 6.82762 & 0.033746 & 0.006632 & 12.0135\end{array}$

$\begin{array}{lll}0.42514 & 6.34075 & 0.029628\end{array}$

0.002334

11.7196

3.41445
3.31904

0.10739

4.05999
4.10077

4.10077
3.70597

$\begin{array}{ll}0.09896 & 0.76090\end{array}$ 0.088520 .84103

$0.11262 \quad 0.45599$

0.116940 .64760

0.110260 .77754

0.130160 .78888

$0.09466,0.57523$

0.110030 .63898

$0.11462 \quad 0.61240$

$0.10633 \quad 0.72423$

0.135200 .90701

$\begin{array}{lll}0.13443 & 0.88254\end{array}$

0.098920 .99459

$0.10225 \quad 0.94315$

0.72029 


$\begin{array}{lcc} & & \text { S } \\ & & \text { A } \\ & \text { I } & \text { P } \\ \text { O } & \text { G } & \text { I } \\ \text { B } & - & \text { E } \\ \text { S } & - & \bar{N} \\ & - & \\ 77 & 9001673 B & W V-44 A-61-4 \\ 78 & 9001672 A & W V-44 A-61-8 \\ 79 & 9001672 B & W V-44 A-61-8 \\ 80 & 9001686 A & W V-44 A-61-12 \\ 81 & 9001686 B & W V-44 A-61-12 \\ 82 & 9001729 A & W V-44 A-74-4 \\ 83 & 9001729 B & W V-44 A-74-4 \\ 84 & 9001627 A & W V-44 A-74-8 \\ 85 & 9001627 B & W V-44 A-74-8 \\ 86 & 9001674 A & W V-44 A-74-12 \\ 87 & 9001674 B & W V-44 A-74-12 \\ 88 & 9001671 A & W V-44 A-86-4 \\ 89 & 9001671 B & W V-44 A-86-4 \\ 90 & 9001709 A & W V-44 A-86-8 \\ 91 & 9001709 B & W V-44 A-86-8 \\ 92 & 9001665 A & W V-44 A-86-12 \\ 93 & 9001665 B & W V-44 A-86-12 \\ 94 & 9001616 A & W V-44 A-S H 1 \\ 95 & 9001607 A & W V-44 A-S H 2\end{array}$

$\begin{array}{ccc} & \text { P } & \text { S } \\ & - & - \\ & - & - \\ \text { C } & \bar{O} & \bar{O} \\ \text { A } & \text { X } & \text { X } \\ \text { N } & \text { D } & \text { I }\end{array}$

B
$\overline{-}$
$\bar{O}$
$\mathrm{X}$
$\mathrm{I}$
$\mathrm{D}$

$\begin{array}{cc}M & Z \\ O & \text { H } \\ - & - \\ \bar{O} & \bar{O} \\ X & X \\ I & I \\ D & D\end{array}$

N
I
-
$\bar{O}$
$\mathrm{X}$
$\mathrm{I}$
$\mathrm{D}$

B
A
-
$\overline{\mathbf{O}}$
$\mathrm{X}$
$\mathrm{I}$
$\mathrm{D}$

$\begin{array}{ll}\text { H } & \text { E } \\ \text { W } & \text { E } \\ - & - \\ \overline{.} & \bar{O} \\ \text { X } & \text { X } \\ \text { I } & \text { I } \\ \text { D } & \text { D }\end{array}$

G
-
$\bar{O}$
$X$
$I$
$D$
5980
75330
0696
8183
86776
1991
91297
91590
93404
76615
80251
64164
51440
91289
90422
67191
71475
90960
80762

$\begin{array}{cccc} & \text { S } & \text { C } & \text { T } \\ & \text { I } & \text { U } & \text { I } \\ & - & - & - \\ & \bar{O} & \bar{O} & \bar{O} \\ O & X & X & X \\ B & I & I & I \\ S & \text { D } & \text { D } & \text { D }\end{array}$

$\begin{array}{llll}44 & 2.59620 & 0.18405 & 10 \\ 44 & 2.57820 & 0.41599 & 10 \\ 44 & 2.56557 & 0.20129 & 10 \\ 44 & 2.62069 & 0.00000 & \\ 44 & 2.59736 & 0.01067 & 10 \\ 44 & 2.58412 & 0.13275 & 10 \\ 44 & 2.60184 & 0.14019 & 10 \\ 44 & 2.58100 & 0.27945 & 10 \\ 44 & 2.58863 & 0.30816 & 10 \\ 44 & 2.63157 & 0.17406 & \\ 44 & 2.58947 & 0.20354 & \\ 44 & 2.55976 & 0.12494 & \\ 44 & 2.59611 & 0.39779 & \\ 44 & 2.53267 & 0.12151 & \\ 44 & 2.55932 & 0.22270 & \\ 44 & 2.60669 & 0.17617 & 10 \\ 44 & 2.59724 & 0.27752 & 10 \\ 44 & 2.50612 & 0.18987 & 10 \\ 44 & 2.54847 & 0.18483 & 10\end{array}$

10.5295

$10.5592 \quad 0.048701$

$20.058696 \quad 0.19397$

0.051293

10.8657

0.21524

0.21131

0.97781

\subsection{6}

11.8363

0.23076

0.21716

0.97343

11.6359

11.7893

12.1936

$\begin{array}{ll}0.19562 & 0.18898 \\ 0.18271 & 0.22857\end{array}$

$0.23272 \quad 1.00371$

10.37880 .048141

0.18271

0.22857
0.22625

0.24288

0.96906

0.050565

0.18528

0.22091

0.24165

0.96565

11.7582

$\begin{array}{llll}0.22489 & 0.96339 & 11.6760\end{array}$

0.98070

11.8902

$0.18772 \quad 0.23506$

0.22008

0.97923

0.49390 .04883

$0.18690 \quad 0.23156$

$\begin{array}{ll}0.5896 & 0.047711\end{array}$

10.6904

0.17312

$\begin{array}{lll}0.22052 & 0.21867 & 0.98075\end{array}$

11.8387

11.8844

$\begin{array}{lll}0.22739 & 0.97208 & 11.7694\end{array}$

$0.24055 \quad 0.95932$

$10.2406 \quad 0.052607$

$\begin{array}{lll}0.17349 & 0.21968\end{array}$

$0.23212 \quad 0.24492$

0.95477

11.6514

$0.17860 \quad 0.21442$

0.22490

0.99328

11.5800

0.048402

0.17318

0.215240 .23195

0.97134

11.9874

10.42990 .048403

0.14197

.245340 .22862

$0.98804 \quad 11.9680$

0.11010

$\begin{array}{lll}047672 & 0.17262 & 0.24143\end{array}$

$\begin{array}{ccc}\text { L } & \text { C } & \\ I & S & K \\ \bar{O} & \bar{O} & \bar{O} \\ X & X & X \\ I & I & I \\ D & D & D \\ E & E & E\end{array}$

$\mathbf{R}$

A $\quad$ S $B$

D II A

$\begin{array}{lll}\mathrm{I} & \mathrm{A} & \mathrm{T} \\ \mathrm{A} & \mathrm{R} & \mathrm{C} \\ \mathrm{H} & \mathrm{D} & \mathrm{I}\end{array}$

D $E$

E. I

$\mathrm{X}$
$\mathrm{I}$
$\mathrm{D}$

$\mathrm{X}$
$\mathrm{I}$
$\mathrm{D}$

$\mathrm{X}$
$\mathbf{I}$
$\mathrm{D}$

D

$\begin{array}{lllll}77 & 43.5821 & 0.061048 & 0.82211\end{array}$

$2.22442 \quad 0.42312$

$6.409390 .029808 \quad 0.023365$

3.32442

0.09431

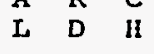

$\begin{array}{ll}\text { T } & \text { II } \\ \text { II } & \text { T }\end{array}$

$\begin{array}{llllll}78 & 43.6637 & 0.072724 & 0.81469 & 2.18063 & 0.45396\end{array}$

$\begin{array}{llllll}79 & 44.0440 & 0.058967 & 0.80728 & 2.19641 & 0.43164 \\ 80 & 41.9606 & 0.051842 & 0.84529 & 2.30949 & 0.49075\end{array}$

$\begin{array}{lllllll}81 & 41.8570 & 0.054606 & 0.84352 & 2.30010 & 0.49743\end{array}$

$\begin{array}{llllll}82 & 43.3409 & 0.053377 & 0.82685 & 2.22847 & 0.52083\end{array}$

$\begin{array}{lllllll}83 & 43.2625 & 0.053841 & 0.82470 & 2.22357 & 0.50254\end{array}$

$\begin{array}{llllll}84 & 43.5047 & 0.060845 & 0.81136 & 2.20786 & 0.49682\end{array}$

$\begin{array}{lllllll}85 & 42.3678 & 0.064486 & 0.82730 & 2.24637 & 0.51574\end{array}$

$\begin{array}{llllll}85 & 42.3678 & 0.064486 & 0.82730 & 2.24637 & 0.51574 \\ 86 & 43.5649 & 0.058999 & 0.82199 & 2.23081 & 0.43391\end{array}$

$\begin{array}{llllll}86 & 43.5649 & 0.058999 & 0.82199 & 2.23081 & 0.43391 \\ 87 & 43.3519 & 0.062290 & 0.82189 & 2.22322 & 0.46844\end{array}$

$\begin{array}{lllllll}88 & 44.3087 & 0.052203 & 0.81111 & 2.22764 & 0.38082\end{array}$

$\begin{array}{llllll}89.44 .1170 & 0.070949 & 0.82534 & 2.21711 & 0.35671\end{array}$

$\begin{array}{llllll}90 & 43.9190 & 0.052632 & 0.80851 & 2.21433 & 0.59199 \\ 91 & 43.7633 & 0.062806 & 0.81147 & 2.19936 & 0.57961\end{array}$

$\begin{array}{llllll}91 & 43.7633 & 0.062806 & 0.81147 & 2.19936 & 0.57961 \\ 92 & 43.3822 & 0.056910 & 0.83886 & 2.28252 & 0.38026\end{array}$

$\begin{array}{llllll}93 & 43.8443 & 0.062180 & 0.82452 & 2.19693 & 0.44511\end{array}$

$94 \quad 44.3246 \quad 0.052292$

0.832412 .25948

0.43056
0.40118

$\begin{array}{ll}.52439 & 0.033251 \\ 6.32606 & 0.030176\end{array}$

$\begin{array}{llll}6.66715 & 0.032370 & 0.02287\end{array}$

11.6557

3.33792

3.60985

$\begin{array}{llll}11.9693 & 3.45236 & 0.09694 & 3.78762\end{array}$

$\begin{array}{llllll}.75684 & 0.033260 & 0.016121 & 11.9628 & 3.43604 & 0.09581\end{array}$

6.67325

0.033260

0.0222111 .9628

3.43604

0.09924 .

$\begin{array}{lll}11.5157 & 3.22514 & 0.09699 \\ 11.5856 & 3.28384 & 0.09125\end{array}$

6.585350 .0323550 .020397

$6.77982 \quad 0.034538$

0.020397

$\begin{array}{lll}11.8450 & 3.35805 & 0.09038\end{array}$

11.6481
11.6706

3.32426

0.09427

$\begin{array}{llll}.10063 & 0.028174 & 0.010585\end{array}$

$\begin{array}{ll}6.08347 & 0.030009\end{array}$

0.043072

.727250 .056405
0.17453

0.043072

11.4518 . 3.32504

0.09433

$\begin{array}{lll}11.6075 & 3.34618 & 0.09137\end{array}$

$\begin{array}{lll}11.3498 & 3.14806 & 0.08994\end{array}$

$\begin{array}{lll}11.4098 & 3.13755 & 0.08549 \\ 11.7738 & 3.34274 & 0.09779\end{array}$

6.17413 0.028549 0.017248

$6.61578 \quad 0.03027$

0.032879

11.5102

3.30269

0.09692
0.09738

$\begin{array}{lll}11.5410 & 3.26819 & 0.09762\end{array}$

3.85678

3.79706

.09108

3.50216

3.52253

3.58213

3.68386

3:45067

3.77686

3.83733

3.58462
3.67756

2.67719

3.69169

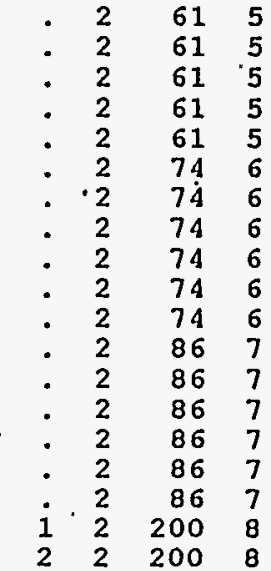




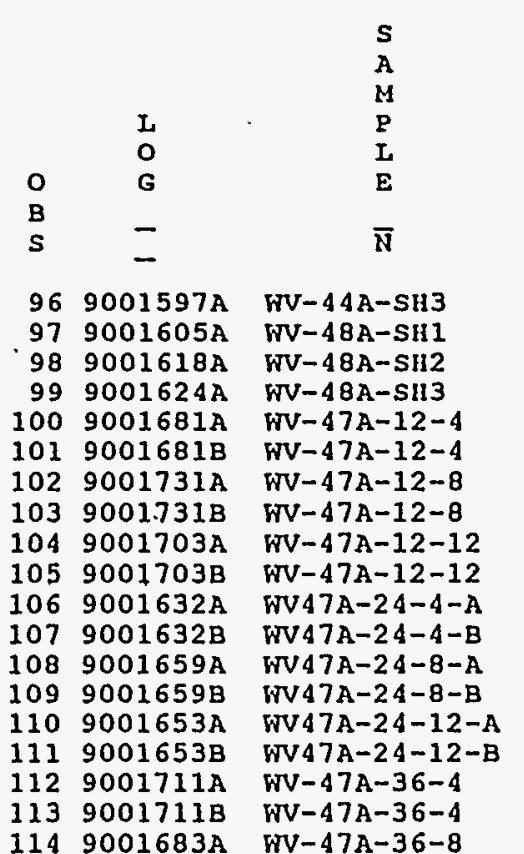

$\begin{array}{cccc} & \text { P } & \text { S } & \text { B } \\ & - & - & - \\ & - & - & \\ & \bar{D} & \bar{O} & \bar{O} \\ \text { C } & \text { X } & \text { X } & \text { X } \\ \text { A } & \text { I } & \text { I } & \text { I } \\ \text { H } & \text { D } & \text { D } & \text { D }\end{array}$

B
-
$\overline{-}$
X
I
D

2.59352 2.63438 2.53389 2.64365 2.57565 2.59965 2.5 .7854 2.61946 $47 \quad 2.60322$ $47 \quad 2.62136$ $47 \quad 2.62417$ 2.60834 2.66634 2.62037 2.60003 $47 \quad 2.57273$ $47 \quad 2.56752$ $47 \quad 2.58592$

0.16807 0.28522 0.23074 0.1787 0.10355 0.18827 0.00000 0.01028 0.20305 0.14083 0.22877 0.17079 0.27021 0.23589 0.13298 $\mathbf{Z}$
$\mathrm{R}$
$-\bar{O}$
$\mathrm{X}$
$\mathrm{I}$
$\mathrm{D}$

$$
\text { C }
$$

A

$\circ$$$
\text { D. D }
$$

$\begin{array}{lllll}96 & 42.5595 & 0.054784 & 0.76172\end{array}$ $9741.9446 \quad 0.058877 \quad 0.77105$ $\begin{array}{lllll}98 & 43.3774 & 0.059472 & 0.83903\end{array}$ $\begin{array}{lllll}99 & 41.7828 & 0.057965 & 0.84474\end{array}$ $\begin{array}{llll}100 & 43.2302 & 0.055022 & 0.81213\end{array}$ $\begin{array}{llll}101 & 43.2789 & 0.053586 & 0.81332 \\ 102 & 42.7746 & 0.057005 & 0.84376\end{array}$ $103 \quad 42.6359$ 10440.8981 $106 \quad 41.9396$ 10742.0266 $108 \quad 42.2663$ $109 \quad 42.4127$ $\begin{array}{lll}110 & 42.2199\end{array}$ $112 \quad 42.7613$ 11343.1104 11443.1844 0.0563400 .95102 0.0632340 .8739 $0.058500 \quad 0.77527$ $0.054082 \quad 0.77014$ $\begin{array}{lll}0.065132 & 0.85272\end{array}$ $0.058716 \quad 0.85135$ $\begin{array}{ll}0.063479 & 0.85074 \\ 0.063826^{\circ} & 0.8467\end{array}$ $\begin{array}{ll}0.063826 & 0.84674 \\ 0.061361 & 0.83071\end{array}$ 0.0672120 .82750 $0.051447 \quad 0.82226$

$\begin{array}{ll}0.48742 & 6.63144 \\ 0.51353 & 6.72369\end{array}$

.295480 .41760

6.55843

0.50638

6.78757

2.2749

0.50638

$\begin{array}{llll}2.28129 & 0.50537 & 6.58616\end{array}$

2.31223

0.51298

6.66645

6.59361

2.40259

0.53328

2.36550

2.349550 .44960

2.35807

2.34965

2.25518

0.43024

0.44684
0.52937

0.50147 6.85940

6.68451

6.65771

6.46782

6.27386

6.72757 .

6.69467

0.030298

$\begin{array}{ll}M & \\ O & \\ \bar{O} & \\ \mathrm{X} & \\ \mathrm{D} & \end{array}$

$z$
II
$\bar{D}$
$\mathrm{X}$
$\mathrm{I}$
$\mathrm{D}$

M
H
O
$\mathrm{X}$
$\mathrm{I}$

$$
\begin{aligned}
& \text { E } \\
& \text { E } \\
& - \\
& \bar{O} \\
& \text { X } \\
& \text { I } \\
& \text { D }
\end{aligned}
$$

$\overline{0}$

$\overline{0}$

0.048210
0.049842

0.17658
0.19441

0.24395
0.25069

0.22933

0.99231

12.0925

0.0511310 .161270 .25443

.21337

0.99991

12.0969

0.0480450 .203430 .206590 .21161

0.99773

12.0969
12.2329

$0.20343 \quad 0.20659$

0.20756

0.98335

$0.049710 \quad 0.20906$

$0.050767 \quad 0.20793$

$0.048513 \quad 0.20993$

$0.23391 \quad 0.22013$

0.239740 .219130 .98351

0.20856

0.21933

0.97783

12.0189

.16735 0.92034

0.050357 0.23351 0.21263

0.22101

1.00969

12.1057

0.89056

$\begin{array}{llllllll}0.050357 & 0.23351 & 0.23370 & 0.19716 & 1.00468 & 12.3821 & 0.12181 & 0.92632 \\ 0.047711 & 0.31495 & 0.22302 & 0.18779 & 1.00612 & 12.3767 & 0.11610 & 0.93673\end{array}$

$\begin{array}{llllllll}050357 & 0.23351 & 0.23370 & 0.19716 & 1.00468 & 12.3821 & 0.12181 & 0.92632 \\ 047711 & 0.31495 & 0.22302 & 0.18779 & 1.00612 & 12.3767 & 0.11610 & 0.93673\end{array}$

$\begin{array}{llllllll}050357 & 0.23351 & 0.23370 & 0.19716 & 1.00468 & 12.3821 & 0.12181 & 0.92632 \\ 047711 & 0.31495 & 0.22302 & 0.18779 & 1.00612 & 12.3767 & 0.11610 & 0.93673\end{array}$

12.0392

0.06375

$0.11229-0.92558$

0.119170 .86029

0.053640 .96281

$\begin{array}{lllllllll}0.052181 & 0.22767 & 0.23749 & 0.19591 & 1.00300 & 12.3083 & 0.11429 & 0.74020\end{array}$

$\begin{array}{llllllll}0.049199 & 0.22677 & 0.22797 & 0.19484 & 1.00628 & 12.3458 & 0.10894 & 0.74112\end{array}$

$\begin{array}{lllllllll}0.052208 & 0.22869 & 0.24418 & 0.19749 & 1.00952 & 12.3774 & 0.11734 & 0.58079 \\ 0.0068 & 12.3458 & 0.11654 & 0.70153\end{array}$

$\begin{array}{lllllllll}0.049730 & 0.22943 & 0.22637 & 0.19757 & 0.97023 & 11.9742 & 0.09382 & 0.91183\end{array}$

$\begin{array}{llllllll}0.052865 & 0.22697 & 0.23275 & 0.20407 & .0 .95895 & 11.8305 & 0.10151 & 0.89827\end{array}$

$0.046916 \quad 0.22650$

0.85335

$\begin{array}{cc}\text { S } & \text { L } \\ \text { R } & \text { A } \\ - & - \\ \bar{O} & \quad \\ \text { X } & \text { D } \\ \text { I } & \text { X } \\ \text { D } & \text { D }\end{array}$

$\begin{array}{ll}\text { I } & \text { I } \\ \text { A } & \text { I } \\ \bar{D} & \text { O } \\ \text { X } & \text { X } \\ \text { I } & \text { I } \\ \text { D } & \text { D } \\ \text { E } & \text { E }\end{array}$

L
$I$
O
$X$
$I$
$D$
$E$

C
S
O
$X$
$I$
$D$
E

.030693

0.019190

$\begin{array}{lll}0.019795 & 0.018703 & 11.8578\end{array}$

3.32996
3.34395

0.09901
0.10352

11.6298

$3.23157 \quad 0.10347$

$\begin{array}{ll}031314 & 0.013749 \\ 032554 & 0.03115\end{array}$

.0329150 .037314

0.034612

0.0311760 .013414

11.8627

3.32917

11.6715

11.6622

11.7434
12.1558

12.1963

11.8252

3.278750 .10218

$3.288330 .10115 \quad 3.5817$

$\begin{array}{lll}3.20611 & 0.10681 & 4.00419\end{array}$

$3.45617 \quad 0.10763$

$3.46777 \quad 0.11049$

$\begin{array}{lll}3.34932 & 0.10082\end{array}$

3. 34026

0.10082

11.8924

3.354330 .10275

$3.39205 \quad 0.09831$

3.34110 .09906

$3.21789 \quad 0.09555$

$\begin{array}{ll}3.27903 & 0.09971\end{array}$

$\begin{array}{lllll}\text { R } & & & & \text { H } \\ \text { A } & \text { S } & \text { B } & \text { D } & \text { E } \\ \text { D } & \text { H } & \text { A } & \text { E } & \text { I } \\ \text { I } & \text { A } & \text { T } & \text { P } & \text { G } \\ \text { A } & \text { R } & \text { C } & \text { T } & \text { II } \\ \text { L } & \text { D } & \text { H } & \text { H } & \text { T }\end{array}$

3.75617

3.64162

$\begin{array}{lllll}12 & 3 & 2 & 200 & 8\end{array}$

$\begin{array}{llll}1 & 3 & 0 & 0 .\end{array}$

3

(1)

$\begin{array}{ll}0 & 0 \\ 0 & 0\end{array}$

$\begin{array}{ll}12 & 1 \\ 12 & 1\end{array}$

$12 \quad 1$

121

$\begin{array}{ll}12 & 1 \\ 12 & 1\end{array}$

242.

242

242

242

$24 \quad 2$

363

$\begin{array}{ll}36 & 3 \\ 36 & 3\end{array}$ 


$\begin{array}{lcc} & & S \\ & & \text { A } \\ & \text { L } & \text { P } \\ \text { O } & \text { G } & \text { L } \\ \text { B } & - & \bar{N} \\ \text { S } & - & \\ & - & \\ 115 & 9001683 B & W V-47 A-36-8 \\ 116 & 9001733 A & W V-47 A-36-12 \\ 117 & 9001733 B & W V-47 A-36-12 \\ 118 & 9001688 A & W V-47 A-50-4 \\ 119 & 9001688 B & W V-47 A-50-4 \\ 120 & 9001678 A & W V-47 A-50-8 \\ 121 & 9001678 B & W V-47 A-50-8 \\ 122 & 9001680 A & W V-47 A-50-12 \\ 123 & 9001680 B & W V-47 A-50-12 \\ 124 & 9001687 A & W V-47 A-63-4 \\ 125 & 9001687 B & W V-47 A-63-4 \\ 126 & 9001670 A & W V-47 A-63-8 \\ 127 & 9001670 B & W V-47 A-63-8 \\ 128 & 9001657 A & W V-47 A-63-12 \\ 129 & 9001657 B & W V-47 A-63-12 \\ 130 & 9001734 A & W V-47 A-76-4 \\ 131 & 9001734 B & W V-47 A-76-4 \\ 132 & 9001735 A & W V-47 A-76-8 \\ 133 & 9001735 B & W V-47 A-76-8\end{array}$

\begin{tabular}{|c|c|c|}
\hline & P & $s$ \\
\hline & - & - \\
\hline & - & - \\
\hline & $\overline{\mathbf{o}}$ & $\overline{\mathrm{o}}$ \\
\hline C & $x$ & $x$ \\
\hline$\AA$ & I & $I$ \\
\hline $\mathbf{N}$ & D & $D$ \\
\hline
\end{tabular}

B
-
$\overline{-}$
$\overline{0}$
$\mathbf{x}$
I

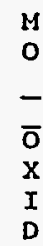

$2.59497 \quad 0.16997$ $\begin{array}{lll}2.62662 & 0.00385 & 10.707\end{array}$

2.59996

2.66054

$2.62708 \quad 0.06294$

2.588180 .15185

$2.54370 \quad 0.12187$

$\begin{array}{lll}2.57366 & 0.16714\end{array}$

2.663030 .00413

2.64391

2.553470 .15943

2.55640

2.65532

0.28242
0.37540

2.60327

2.61564

$47 \quad 2.61559$

0.06819

0.07780

.0908510 .6319 10.5625 10.9926 11.074 10.5412
$\begin{array}{ll}M & Z \\ \text { O } & \text { W } \\ - & - \\ \bar{O} & \bar{O} \\ \mathrm{X} & \mathrm{X} \\ \mathrm{I} & \mathrm{I} \\ \mathrm{D} & \mathrm{D}\end{array}$

$z$
H
$\bar{O}$
$\mathrm{X}$
$\mathrm{I}$
$\mathrm{D}$

$0.048166 \quad 0.22645$ $\begin{array}{lll}0.047135 & 0.23108 & 0.22376\end{array}$ $\begin{array}{lll}0.046146 & 0.22983 & 0.20384\end{array}$ $\begin{array}{lll}0.052864 & 0.24903 & 0.20208\end{array}$ $\begin{array}{lll}0.049744 & 0.24664 & 0.19806\end{array}$ $0.044146 \quad 0.24556$ $0.049376 \quad 0.24236$ $0.047605 \quad 0.23880 \quad 0.19821$ $\begin{array}{llll}0.047043 & 0.25705 & 0.20011\end{array}$ $\begin{array}{llll}10.8534 & 0.047043 & 0.25705 & 0.20011 \\ 10.8759 & 0.047937 & 0.26497 & 0.19953 \\ 10.5625 & 0.051420 & 0.24797 & 0.23476\end{array}$ $\begin{array}{lll}0.051420 & 0.24797 & 0.23476 \\ 0.050900 & 0.24964 & 0.23719\end{array}$ $\begin{array}{lll}0.053850 & 0.26194 & 0.24033\end{array}$ $\begin{array}{llll}0.058977 & 0.26348 & 0.24357\end{array}$ $\begin{array}{lll}0.047672 & 0.26023 & 0.21483\end{array}$ $\begin{array}{lll}0.048959 & 0.26252 & 0.21715\end{array}$ $0.049170 \quad 0.26204$ 0.23008 0.262210 .22986

B
A
-
$\bar{O}$
X
I
D $\begin{array}{ll}\text { H } & \text { E } \\ \text { N } & \text { E } \\ - & - \\ \bar{O} & \bar{O} \\ \text { X } & X \\ \text { I } & \text { I } \\ \text { D } & \text { D }\end{array}$

E
E
$\bar{O}$
$X$
I
$D$

$\begin{array}{cc}\text { C } & \text { M } \\ \text { R } & \text { G } \\ - & - \\ \bar{O} & \bar{O} \\ \text { X } & \text { X } \\ \text { I } & \text { I } \\ \text { D } & \text { D }\end{array}$ $\begin{array}{lllll}0.19620 & 0.99866 & 12.3453 & 0.08511 & 0.78640\end{array}$ $\begin{array}{lllll}0.20114 & 0.99688 & 12.2283 & 0.07277 & 0.90570\end{array}$ $\begin{array}{lllll}0.19155 & 1.01563 & 12.5395 & 0.09189 & 0.85844\end{array}$ $\begin{array}{llllll}0.18741 & 1.02111 & 12.6226 & 0.08779 & 0.83887\end{array}$ $\begin{array}{lllll}0.18153 & 1.00167 & 12.3161 & 0.11775 & 0.91900\end{array}$ $\begin{array}{lllll}0.17917 & 0.98959 & 12.1546 & 0.11591 & 0.85398\end{array}$ $\begin{array}{llllll}0.17667 & 0.99032 & 12.1312 & 0.06575 & 0.82793\end{array}$ $0.18404 \quad 0.98601 \quad 12.0408 \quad 0.06000 \quad 0.91477$ $0.17994 \quad 1.02483 \quad 12.6454 \quad 0.08668 \quad 0.05817$ $0.17302 \quad 1.02302 \quad 12.65990 .089170 .75102$ $\begin{array}{lllll}0.16575 & 0.99261 & 12.2226 & 0.11482 & 0.70024\end{array}$ $\begin{array}{lllll}0.16998 & 0.99574 & 12.2689 & 0.11919 & 0.66443\end{array}$ $\begin{array}{lllll}0.15347 & 1.00888 & 12.4987 & 0.09298 & 0.55721\end{array}$ $\begin{array}{lllll}0.16120 & 1.01090 & 12.4471 & 0.09173 & 0.49703\end{array}$

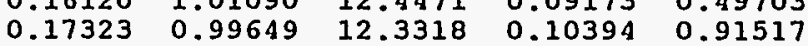
$0.16293 \quad 0.99991 \cdot 12.3977 \quad 0.101990 .78696$ $\begin{array}{llllll}0.16585 & 0.99806 & 12.4777 & 0.10474 & 0.79736\end{array}$ $\begin{array}{lllll}0.16711 & 0.99985 & 12.4700 & 0.10534 & 0.71138\end{array}$

\begin{tabular}{|c|c|c|c|c|c|c|c|}
\hline $\begin{array}{l}\mathrm{L} \\
\mathrm{I}\end{array}$ & $\begin{array}{l}\mathbf{C} \\
\mathbf{S}\end{array}$ & K & & & & & \\
\hline & & & $\mathbf{R}$ & & & & H \\
\hline$\overline{0}$ & $\overline{0}$ & $\overline{0}$ & A & $\mathbf{s}$ & B & D & $\mathbf{E}$ \\
\hline $\mathrm{x}$ & $\mathrm{x}$ & $x$ & D & й & $A$ & E & I \\
\hline I & I & I. & I & A & $\mathbf{T}$ & P & $\mathbf{G}$ \\
\hline D & D & D & A & $\mathbf{R}$ & C & $T$ & II \\
\hline $\mathbf{E}$ & E & E & I & D & II & II & T \\
\hline 8598 & 0.09664 & 3.57816 & 8 & . & 3 & 36 & 3 \\
\hline 109 & 0.10978 & 3.95171 & 12 & . & 3 & 36 & 3 \\
\hline 32777 & 0.10964 & 3.98344 & 12 & . & 3 & 36 & 3 \\
\hline 44966 & 0.10143 & 3.75556 & 4 & . & 3 & 50 & 4 \\
\hline 44096 & 0.10255 & 3.75767 & 4 & . & 3 & 50 & 4 \\
\hline 32355 & 0.10257 & 3.66599 & 8 & . & 3 & 50 & 4 \\
\hline 30496 & 0.10149 & 3.54801 & $\theta$ & . & 3 & 50 & 4 \\
\hline 30164 & 0.10261 & 3.66277 & 12 & . & 3 & 50 & 4 \\
\hline 29163 & 0.10230 & 3.58369 & 12 & . & 3 & 50 & 4 \\
\hline 45397 & 0.10312 & 3.78851 & $\cdot 4$ & . & 3 & 63 & 5 \\
\hline 45031 & 0.10396 & 3.92167 & 4 & . & 3 & 63 & 5 \\
\hline 34222 & 0.09506 & 3.68941 & 8 & . & 3 & 63 & 5 \\
\hline 34439 & 0.10794 & 3.75580 & 8 & . & 3 & 63 & 5 \\
\hline 33329 & 0.10548 & 3.74741 & 12 & . & 3 & 63 & 5 \\
\hline 35685 & 0.09414 & 3.73420 & 12 & $:$ & 3 & 63 & 5 \\
\hline 29556 & 0.09971 & 4.02886 & 4 & . & 3 & 76 & 6 \\
\hline 29507 & 0.10491 & 4.11780 & 4 & . & 3 & 76 & 6 \\
\hline & 0.1 .0544 & 4.12762 & 8 & . & 3 & 76 & 6 \\
\hline 250 & 0.10767 & 4.08169 & 8 & . & 3 & 76 & 6 \\
\hline
\end{tabular}

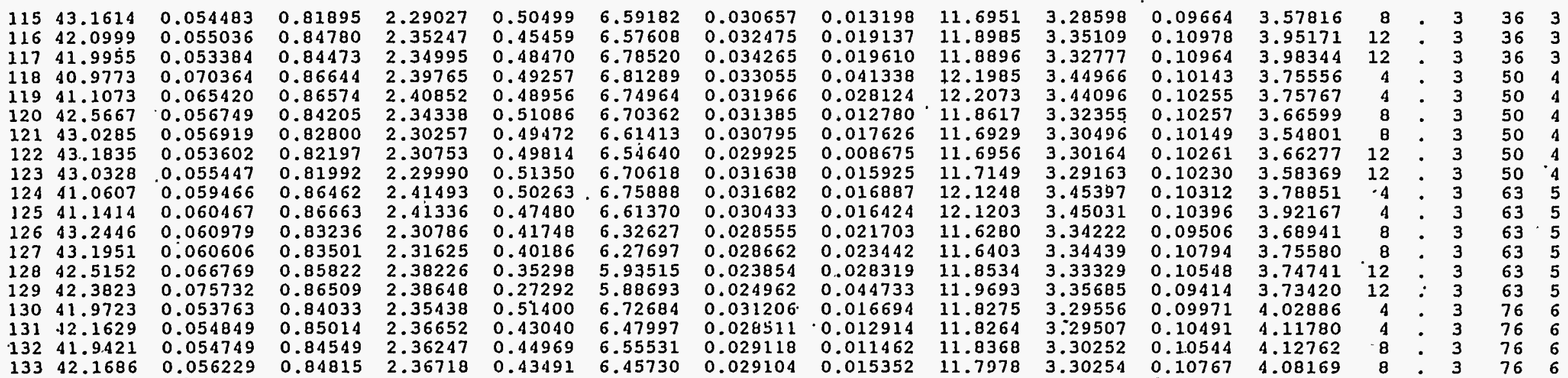


The SAS system

12:23 Friday, December 21, 199010

$\mathbf{S}$
$\mathrm{A}$
$\mathrm{M}$
$\mathrm{P}$
$\mathrm{L}$
$\mathrm{E}$
$\bar{N}$

$1349001675 \mathrm{~A}$ WV $-47 A-76-12$ $1359001675 \mathrm{~B}$ WV-47A-76-12 $1359001675 \mathrm{~B}$ $1369001655 \cdot \mathrm{A}$ TV $-47 A-80-8$ $1399001651 \mathrm{~B}$ FV $-47 \mathrm{~A}-88-8$ $1409001676 \mathrm{~A}$ WV-47A-88-12 $1419001676 \mathrm{~B}$ WV-47A-88-12 $1429001626 \mathrm{~A}$ WV-47A-SH1 $\begin{array}{lll}143 & 9001596 A & \text { WV } \\ 144 & 9001609 A & \text { WV }-47 A-S H 3\end{array}$

$\cdot \cdot \cdot$
C
A
N

$\begin{array}{ll}\text { C } & \text { T } \\ \text { O } & \text { I } \\ - & - \\ \bar{O} & \bar{D} \\ \text { X } & \text { X } \\ \text { I } & \text { I } \\ \text { D } & \text { D }\end{array}$

$\begin{array}{llll}134 & 42.7146 & 0.061347\end{array}$

13542.7156

0.061347
0.064869

0.84395

.0663940 .85240

$\begin{array}{ll}0.064918 & 0.85497 \\ 0.060676 & 0.83079\end{array}$

$\begin{array}{ll}0.060676 & 0.83079 \\ 0.061801 & 0.83547\end{array}$

$\begin{array}{ll}0.061801 & 0.83547 \\ 0.071191 & 0.85464 \\ 0.061205 & 0.84393\end{array}$

$138 \quad 42.6523$

13942.8141

$\begin{array}{lllll}141 & 42.5442 & 0.061205 & 0.84393 \\ 142 & 41.1139 & 0.068827 & 0.85379 \\ 143 & 41.5044: & 0.057829 & 0.77915\end{array}$

$14341.5044: 0.05$

$\begin{array}{ll}0.77915 & 2.38076 \\ 0.83998 & 2.32927\end{array}$
$2.60619 \quad 0.25171$

$\begin{array}{ll}2.60010 & 0.22980 \\ 2.55252 & 0.24975\end{array}$

$\begin{array}{ll}2.55252 & 0.24975 \\ 2.64039 & 0.25800\end{array}$

2.62073

0.11834

0.26563

2.63023

0.16924

$\mathbf{Z}$
$\mathbf{R}$
-
$\bar{O}$
$\mathrm{X}$
$\mathrm{I}$
$\mathrm{D}$

C
A
-
$\bar{O}$
$X$
$I$
$D$

$M$
$O$
-
$\bar{O}$
$X$
$I$
$D$

Z
1
-
$\bar{O}$
$\mathrm{X}$
$\mathrm{I}$
$\mathrm{D}$

N
I
-
$\bar{O}$
$\mathrm{X}$
$\mathrm{I}$
$\mathrm{D}$

$10.5560 \quad 0.047089$

0.26386

0.23591

$10.9341,0.053488$

$\begin{array}{lll} & 0.26432 \\ & 0.27691\end{array}$

0.24316

10.50190 .048365

$\begin{array}{lll}0.5653 & 0.048995 & 0.26903\end{array}$

0.22561

0.052207

$\begin{array}{ll}10.6371 & 0.052207 \\ 0.04769 & 0.26991\end{array}$

$\begin{array}{lll}10.6569 & 0.049109 & 0.28076\end{array}$

0.23539

0.22154

10.5717

$\begin{array}{rr}0.049109 & 0.28076 \\ .0 .048756 & 0.27478\end{array}$

0.25539

0.25012

$\begin{array}{ll}S & \text { L } \\ \text { R } & \text { A } \\ - & - \\ \bar{O} & \bar{O} \\ X & \text { X } \\ \text { I } & \text { I } \\ \text { D } & \text { D }\end{array}$

$\begin{array}{ll}\text { N } & \text { I } \\ \text { A } & \text { I } \\ \text { O } & \text { O } \\ \text { X } & \text { X } \\ \text { I } & \text { I } \\ \text { D } & \text { D } \\ \text { E } & \text { E }\end{array}$

2.34308

. 37399

2.38393

$\begin{array}{ll}.42226 & 6.41430 \\ 0.40725 & 6.41539\end{array}$

0.46483

0.45175

6.41539
6.47831

$0.028218 \quad 0.018188$

0.0282950 .024731

$\begin{array}{ll}0.030835 & 0.033250 \\ 0.030132 & 0.029609\end{array}$

0.46579
0.42623

6.36126
6.60609

0.0298690 .029609

0.37572

$\begin{array}{lll}6.34488 & 0.028293 & 0.034039\end{array}$

$6.51160 \quad 0.029077 \quad 0.018698$

$0.53295 \quad 6.04549$

$\begin{array}{ll}0.029077 & 0.018698 \\ 0.033915 & 0.042117\end{array}$

0.54691

6.77621

$\begin{array}{lll}0.033915 & 0.042117 & 11.9973 \\ 0.031335 & 0.019774 & 11.8564\end{array}$

$\begin{array}{lllll}6.77621 & 0.031335 & 0.019774 & 11.8564 & 3.34070 \\ 6.27369 & 0.026950 & 0.014660 & 11.7473 & 3.30143\end{array}$

$1.7605 \quad 3.29596$

11.9486 3.32572

$1.9287 \quad 3.41409$

3.31072

B
-
$\overline{-}$
$\bar{O}$
X
I
D

0.277540 .22601

$\begin{array}{lll}6.46895 & 0.028582 & 0.022753\end{array}$

$$
\begin{array}{r}
\text { B } \\
\text { A } \\
- \\
\bar{O} \\
\text { X } \\
\text { I } \\
\text { D }
\end{array}
$$

$\begin{array}{ll}\text { H } & \text { E } \\ \text { N } & \text { E } \\ - & - \\ \bar{O} & \bar{O} \\ \text { X } & \text { X } \\ \text { I } & \text { I } \\ \text { D } & \text { D }\end{array}$

$E$
$E$
-
$\bar{O}$
$X$
$I$
$D$

C
R
-
$\bar{O}$
$\mathrm{X}$
$\mathrm{I}$
$\mathrm{D}$

G

$-$

$\mathrm{O}$
$\mathrm{I}$

0.99980

0.99771

$12.3686 \quad 0.12408$

$12.3515,0.12802$

$\begin{array}{llll}0.16528 & 1.01419 & 12.5392 & 0.09056 \\ 0.15684 & 0.99040 & 12.1983 & 0.10767\end{array}$

$0.15540 \quad 0.99141$

$12.2876 \quad 0.11671$

0.99338

0.99687

1.00736

12.2919

12.51690 .10718

12.53470 .16540

0.16540

.81394

0.76879

0.69176

0.62748

0.87112

0.80524

0.69841

0.79301

0.93430

0.75334
$12.4482 \quad 0.08952$

12.31350 .11481

$K$
$\bar{O}$
$X$
$I$
$D$
$E$

$\begin{array}{lll}\mathrm{R} & & \\ \mathrm{A} & \mathrm{S} & \mathrm{B} \\ \mathrm{D} & \mathrm{H} & \mathrm{A} \\ \mathrm{I} & \mathrm{A} & \mathrm{T} \\ \mathrm{A} & \mathrm{R} & \mathrm{C} \\ \mathrm{I} & \mathrm{D} & \mathrm{H}\end{array}$

D

E I

$\begin{array}{ll}\mathrm{E} & \mathrm{I} \\ \mathrm{P} & \mathrm{G}\end{array}$

II $T$

0.09924

0.10022

0.10886

0.10473

0.09682

0.10019

0.10436

0.10217

0.10507
0.10379

3.69989

$3.58291 \quad 12: 3376$

$3.703974: 3887$

3.66619

3.62873

3.61582

3.44730

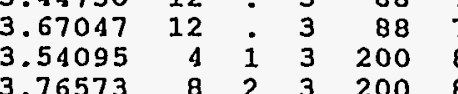

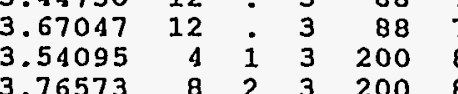
. 